\title{
One-Shot Synthesis of Expanded Heterohelicene Exhibiting Narrowband Thermally Activated Delayed
}

\section{Fluorescence}

Susumu Oda, Bungo Kawakami, Yuki Yamasaki, Ryuji Matsumoto, Mayu Yoshioka, Daisuke Fukushima, Soichiro Nakatsuka, and Takuji Hatakeyama*

Prof. Dr. T. Hatakeyama, Dr. S. Oda, B. Kawakami, Y. Yamasaki, Dr. S. Nakatsuka

Department of Chemistry, Graduate School of Science and Technology, Kwansei Gakuin University, 2-1 Gakuen, Sanda, Hyogo 669-1337, Japan

E-mail: hatake@kwansei.ac.jp

Dr. R. Matsumoto, M. Yoshioka, D. Fukushima

Advanced Material Development Laboratory, Sumitomo Chemical Co., Ltd., 6 Kitahara, Tsukuba, Ibaraki 300-3294, Japan 


\section{EXPERIMENTAL SECTION}

General Procedure. All the reactions dealing with air- or moisture-sensitive compounds were carried out in a dry reaction vessel (small scale, a Schlenk flask; large scale, a three-neched round bottomed flask) under a positive pressure of nitrogen. Air- and moisture-sensitive liquids and solutions were transferred via a syringe or a Teflon cannula. Analytical thin-layer chromatography (TLC) was performed on glass plates coated with $0.25 \mathrm{~mm} \mathrm{230-400} \mathrm{mesh} \mathrm{silica} \mathrm{gel} \mathrm{containing} \mathrm{a}$ fluorescent indicator (Merck, \#1.05715.0009). TLC plates were visualized by exposure to ultraviolet light (254 $\mathrm{nm}$ or $365 \mathrm{~nm}$ ) and/or by immersion in a basic staining solution of $\mathrm{KMnO}_{4}$ followed by heating on a hot plate. Organic solutions were concentrated by rotary evaporation at $c a$. 10-50 mmHg. Flash column chromatography was performed on Merck silica gel 60 (spherical, neutral, 140-325 mesh) as described by Still et al. ${ }^{1}$ Gel permeation chromatography was performed on a JAIGEL-1H and 2H (20 mm i.d.) with an LC-9130 (Japan Analytical Industry Co., Ltd.). Proton nuclear magnetic resonance $\left({ }^{1} \mathrm{H} \mathrm{NMR}\right)$, carbon nuclear magnetic resonance $\left({ }^{13} \mathrm{C}\right.$ NMR), boron nuclear magnetic resonance $\left({ }^{11} \mathrm{~B} \mathrm{NMR}\right)$, fluorine nuclear magnetic resonance $\left({ }^{19} \mathrm{~F}\right.$ NMR) spectra, and phosphrus nuclear magnetic resonance $\left({ }^{31} \mathrm{P} \mathrm{NMR}\right)$ spectra were recorded on JEOL ECX400 (400 MHz) NMR spectrometers or JEOL ECX500 (500 MHz) or ECZ500R/S1 $(500 \mathrm{MHz})$ NMR spectrometers. Proton chemical shift values are reported in parts per million (ppm, $\delta$ scale) downfield from tetramethylsilane and are referenced to the tetramethylsilane $(\delta 0), \mathrm{CD}_{2} \mathrm{Cl}_{2}$ $\left(\delta\right.$ 5.32), $\left(\mathrm{CDCl}_{2}\right)_{2}(\delta 6.00)$, bromoform- $d_{1}(\delta 6.83)$, o-dichlorobenzene- $d_{4}(\delta 6.94)$ or $\mathrm{CDCl}_{3}(\delta$ 7.26). ${ }^{13} \mathrm{C}$ NMR spectra were recorded at $101 \mathrm{MHz}$ or $126 \mathrm{MHz}$ : carbon chemical shift values are reported in parts per million (ppm, $\delta$ scale) downfield from tetramethylsilane, and are referenced to the carbon resonance of tetramethylsilane $(\delta 0)$, bromoform- $d_{1}(\delta 10.2), \mathrm{CD}_{2} \mathrm{Cl}_{2}(\delta 53.8),\left(\mathrm{CDCl}_{2}\right)_{2}$ $(\delta 73.8)$, or $\mathrm{CDCl}_{3}(\delta 77.0) .{ }^{11} \mathrm{~B} \mathrm{NMR}$ spectra were recorded at $128 \mathrm{MHz}$ or $160 \mathrm{MHz}$ : boron chemical shift values are reported in parts per million (ppm, $\delta$ scale) and are referenced to the external standard boron signal of $\mathrm{BF}_{3} \cdot \mathrm{Et}_{2} \mathrm{O}(\delta 0)$. Data are presented as: chemical shift, multiplicity ( $\mathrm{s}=$ singlet, $\mathrm{d}=$ doublet, $\mathrm{t}=$ triplet, $\mathrm{q}=$ quartet, quint $=$ quintet, $\mathrm{sext}=$ sextet, $\mathrm{sept}=$ septet, $\mathrm{m}=$ multiplet and/or multiplet resonances, br = broad), coupling constant in hertz $(\mathrm{Hz})$, signal area integration in natural numbers, and assignment (italic). IR spectra were recorded on an ATR-FTIR spectrometer (FT/IR-4200, JASCO or IRAffinity-1S, Shimadzu). Characteristic IR absorptions are reported in $\mathrm{cm}^{-1}$. Melting points were recorded on a Fisher-Johns 12-144-1Q melting point apparatus (according to the limitations of the apparatus, the compounds which did not melt up to $300{ }^{\circ} \mathrm{C}$ are presented as $">300{ }^{\circ} \mathrm{C} "$ after confirming that is not decomposed using NMR). High-resolution mass spectra (HRMS) were obtained by the electron impact (EI) method with a JEOL JMS-T100GCv instrument, by the atmospheric pressure chemical ionization (APCI) method

(1) Still, W. C.; Kahn, M.; Mitra, A. J. Org. Chem. 1978, 43, 2923-2925. 
with a BRUKER DALTONICS micrOTOF instrument, and by the electrospray ionization (ESI) method or the direct analysis in real time (DART) method with IonSense SVP100 and JEOL JMS-T100LP instruments. Low-resolution mass spectra (LRMS) were obtained by the electron impact (EI) method with a Shimadzu GCMS-QP2010 Ultra instrument. UV-visible absorption spectra were measured by a Shimazu UV-2600 instrument. Fluorescence spectra were measured by a HORIBA Scientific FluoroMax-4 instrument. Absolute PL quantum yields were recorded on a Hamamatsu Photonics Quantaurus-QY instrument. Fluorescence lifetimes were recorded on a Hamamatsu Photonics Quantaurus-Tau instrument. Purity of isolated compounds was determined by ${ }^{1} \mathrm{H}$ NMR analyses, GC analysis on a Shimadzu GC-2025 instrument equipped with an FID detector and a capillary column (ZB-1MS, Phenomenex, $10 \mathrm{~m} \times 0.10 \mathrm{~mm}$ i.d., $0.10 \mathrm{~mm}$ film thickness), or HPLC analysis on a JASCO UV-2070 Plus instrument equipped with a reversed-phase $\mathrm{C} 18$ column (InertSustain ${ }^{\mathrm{TM}} \mathrm{C} 18$, GL Siences Inc., $4.6 \mathrm{~mm} \times 250 \mathrm{~mm}$ i.d.).

Materials. Materials were purchased from Wako Pure Chemical Industries, Ltd. (Wako), Tokyo Chemical Industry Co., Ltd., Aldrich Inc., and other commercial suppliers, and were used after appropriate purification, unless otherwise noted. Florisil (100-200 mesh) was purchased from Kanto Chemical Co., Inc. (Kanto).

Solvent. Anhydrous solvents were purchased from above-described suppliers and/or dried over Molecular Sieves 4A and degassed before use. Water content of the solvent was determined with a Karl Fischer moisture titrator (AQ-2200, Hiranuma Sangyo Co., Ltd.) to be less than 20 ppm. 
Computational Method. All calculations were performed with performed with Gaussian $09^{2}$ or ADF $2021^{3}$ packages unless otherwise noted. The DFT method was employed using the B3LYP hybrid functional. ${ }^{4}$ Structures were optimized with the $6-31 \mathrm{G}(\mathrm{d})^{5}$ or $\mathrm{TZP}^{6}$ basis set. The time-dependent density functional theory (TD-DFT) calculation ${ }^{7}$ was conducted at the B3LYP/TZP level after the geometry optimization at the B3LYP/TZP level. Coupled-cluster (CC2) calculations were performed using the TURBOMOL package ${ }^{8}$ with def2-TZVP basis set at the structures optimized at the (TD)B3LYP/TZP level.

(2) Gaussian 09, Revision C.01, Frisch, M. J.; Trucks, G. W.; Schlegel, H. B.; Scuseria, G. E.; Robb, M. A.; Cheeseman, J. R.; Scalmani, G.; Barone, V.; Mennucci, B.; Petersson, G. A.; Nakatsuji, H.; Caricato, M.; Li, X.; Hratchian, H. P.; Izmaylov, A. F.; Bloino, J.; Zheng, G.; Sonnenberg, J. L.; Hada, M.; Ehara, M.; Toyota, K.; Fukuda, R.; Hasegawa, J.; Ishida, M.; Nakajima, T.; Honda, Y.; Kitao, O.; Nakai, H.; Vreven, T.; Montgomery, Jr., J. A.; Peralta, J. E.; Ogliaro, F.; Bearpark, M.; Heyd, J. J.; Brothers, E.; Kudin, K. N.; Staroverov, V. N.; Keith, R.; Kobayashi, R.; Normand, J.; Raghavachari, K.; Rendell, A.; Burant, J. C.; Iyengar, S. S.; Tomasi, J.; Cossi, M.; Rega, N.; Millam, N. J.; Klene, M.; Knox, J. E.; Cross, J. B.; Bakken, V.; Adamo, C.; Jaramillo, J.; Gomperts, R.; Stratmann, R. E.; Yazyev, O.; Austin, A. J.; Cammi, R.; Pomelli, C.; Ochterski, J. W.; Martin, R. L.; Morokuma, K.; Zakrzewski, V. G.; Voth, G. A.; Salvador, P.; Dannenberg, J. J.; Dapprich, S.; Daniels, A. D.; Farkas, Ö.; Foresman, J. B.; Ortiz, J. V.; Cioslowski, J.; Fox, D. J. Gaussian, Inc., Wallingford CT, 2010.

(3) ADF2021, SCM, Theoretical Chemistry, Vrije Universiteit, Amsterdam, The Netherlands, http://www.scm.com/

(4) (a) Becke, A. D. J. Chem. Phys. 1993, 98, 5648-5652. (b) Lee, C.; Yang, W.; Parr, R. G. Phys. Rev. B 1988, 37, 785-789.

(5) Hehre, W. J.; Radom, L.; Schleyer, P. v. R.; Pople, J. A. Ab Initio Molecular Orbital Theory; John Wiley \& Sons: New York, 1986 and references cited therein.

(6) Van Lenthe, E.; Baerends, E. J. J. Comput. Chem. 2003, 24, 1142-1156.

(7) (a) Casida, M. E.; Jamorski, C.; Casida, K. C.; Salahub, D. R. J. Chem. Phys. 1998, 108, 44394449. (b) Stratmann, R. E.; Scuseria, G. E.; Frisch, M. J. J. Chem. Phys. 1998, 109, 8218-8224.

(8) TURBOMOLE V7.4 2019, a development of University of Karlsruhe and Forschungszentrum Karlsruhe $\mathrm{GmbH}$, 1989-2007, TURBOMOLE GmbH, since 2007; available from http://www.turbomole.com. 
Table S1. Summary of TD-DFT Calculation for V-DABNA-Mes and $\boldsymbol{v}$-DABNA at the B3LYP/6-31G(d) Level of Theory (Gaussian 09).

\begin{tabular}{|c|c|c|c|c|c|c|c|c|c|c|}
\hline compound & $\begin{array}{c}\text { HOMO-1 } \\
{[\mathrm{eV}]}\end{array}$ & $\begin{array}{c}\text { HOMO } \\
{[\mathrm{eV}]}\end{array}$ & $\begin{array}{c}\text { LUMO } \\
{[\mathrm{eV}]}\end{array}$ & $\begin{array}{c}\text { LUMO+1 } \\
{[e V]}\end{array}$ & $\begin{array}{c}\lambda_{(\mathrm{S} 0-\mathrm{S} 1)} \\
{[\mathrm{nm}]}\end{array}$ & $\begin{array}{l}E_{S^{a}} \\
{[\mathrm{eV}]}\end{array}$ & $f^{b}$ & $\begin{array}{c}\lambda_{(\mathrm{S} 0-\mathrm{T} 1)} \\
{[\mathrm{nm}]}\end{array}$ & $\begin{array}{l}E_{\mathrm{T}}^{c} \\
{[\mathrm{eV}]}\end{array}$ & $\begin{array}{c}\Delta E_{\mathrm{ST}^{d}}{ }^{\mathrm{eVV}]} \\
\text { [ }\end{array}$ \\
\hline V-DABNA-Mes & -4.64 & -4.47 & -1.23 & -0.91 & 454 & 2.73 & 0.3929 & 496 & 2.50 & 0.23 \\
\hline$v$-DABNA & -4.72 & -4.57 & -1.22 & -0.93 & 428 & 2.90 & 0.6878 & 482 & 2.57 & 0.33 \\
\hline
\end{tabular}

aSinglet-singlet excitation energy. ${ }^{b}$ Oscillator strength. ${ }^{c}$ Singlet-triplet excitation energy. ${ }^{a}$ Energy gap between $\mathrm{S}_{1}$ and $\mathrm{T}_{1}$ states.

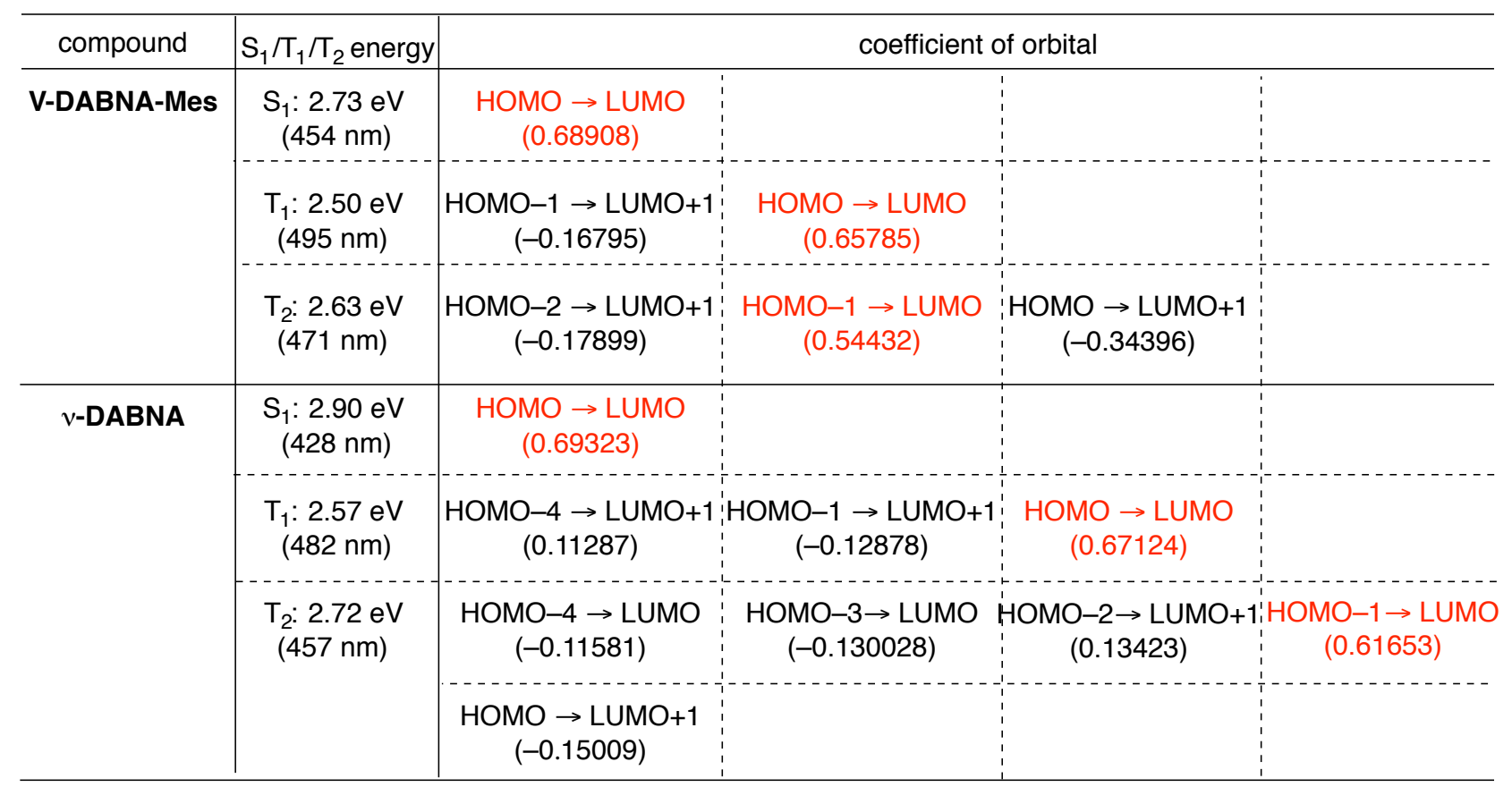

Table S2. $\mathrm{S}_{1}, \mathrm{~T}_{1}$ and $\mathrm{T}_{2}$ Vertical Excitation Energies and Vertical Excitation Energy Gaps for V-DABNA-core, and $\boldsymbol{v}$-DABNA-core at the CC2/def2TZVP//B3LYP/TZP Level of Theory (TURBOMOL).

\begin{tabular}{c|cc:ccc:cc:c:c}
\hline compound & $\begin{array}{c}E_{S 0-S 1} \\
{[\mathrm{eV}]}\end{array}$ & $\begin{array}{c}\%+1 / \% \mathrm{t} 2 \\
{[\%]}\end{array}$ & $\begin{array}{c}E_{\mathrm{SO}-\mathrm{T} 1} \\
{[\mathrm{eV}]}\end{array}$ & $\begin{array}{c}\% \mathrm{t} 1 / \% \mathrm{t} 2 \\
{[\%]}\end{array}$ & $\begin{array}{c}E_{\mathrm{SO}-\mathrm{T} 2} \\
{[\mathrm{eV}]}\end{array}$ & $\begin{array}{c}\% \mathrm{t} 1 / \% \mathrm{t} 2 \\
{[\%]}\end{array}$ & $\begin{array}{c}\Delta E_{\mathrm{S} 1-\mathrm{T} 1} \\
{[\mathrm{meV}]}\end{array}$ & $\begin{array}{c}\Delta E_{\mathrm{S} 1-\mathrm{T} 2} \\
{[\mathrm{meV}]}\end{array}$ \\
\hline V-DABNA-core & 2.980 & $86.26 / 13.74$ & 2.976 & $87.55 / 12.45$ & 3.074 & $87.74 / 12.26$ & 4 & 94 \\
\hline v-DABNA-core & 3.074 & $86.43 / 13.57$ & 3.004 & $87.91 / 12.09$ & 3.151 & $87.77 / 12.23$ & 70 & 77 \\
\hline
\end{tabular}


Table S3. Summary of Photophysical Data of V-NTP-Mes in PMMA Film and V-DABNA in DOBNA-OAr Film (1 wt \%, Excited at $365 \mathrm{~nm})$.

\begin{tabular}{c|ccccccc:cc}
\hline compound & $\begin{array}{c}\lambda_{\mathrm{ab}}{ }^{a} \\
{[\mathrm{~nm}]}\end{array}$ & $\begin{array}{c}\lambda_{\mathrm{em}}{ }^{b} \\
{[\mathrm{~nm}]}\end{array}$ & $\begin{array}{c}\mathrm{FWHM}^{c} \\
{[\mathrm{~nm}]}\end{array}$ & $\begin{array}{c}\Phi^{d} \\
{[\%]}\end{array}$ & $\begin{array}{c}\tau_{\mathrm{F}}{ }^{e} \\
{[\mathrm{~ns}]}\end{array}$ & $\begin{array}{c}k_{\mathrm{r}} / k_{\mathrm{nr}}{ }^{f} \\
{\left[10^{7} \mathrm{~s}^{-1}\right]}\end{array}$ & $\begin{array}{c}\lambda_{\mathrm{em}}{ }^{g} \\
{[\mathrm{~nm}]}\end{array}$ & $\begin{array}{c}\Delta E_{\mathrm{ST}^{h}} \\
{[\mathrm{meV}]}\end{array}$ \\
\hline V-DABNA-Mes & 477 & 484 & 16 & 80 & 7.0 & $11 / 2.7$ & 488 & 5.2 \\
\hline v-DABNA $^{i}$ & - & 467 & 18 & 90 & 4.1 & $22 / 2.4$ & 473 & 17 \\
\hline
\end{tabular}

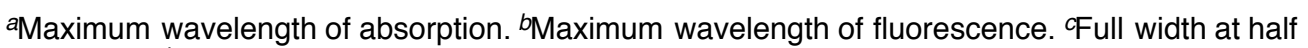
maximum. ${ }^{d}$ Absolute photoluminescence quantum yield. eLifetime of fluorescent (prompt) component. tRadiative and non-radiative rate constants. 9Maximum wavelength of fluorescence and phosphorescence ( $25 \mathrm{~ms}$ delay) at $77 \mathrm{~K}$. hEnergy gap between $\mathrm{S}_{1}$ and $\mathrm{T}_{1}$ states estimated from emission maximum at $77 \mathrm{~K}$. 'ref [9].

Table S4. Summary of Photophysical Data of V-DABNA-Mes in PMMA Film and v-DABNA in DOBNA-OAr Film (1 wt\%, Excited at $365 \mathrm{~nm})$.

\begin{tabular}{|c|c|c|c|c|c|c|c|c|c|}
\hline compound & $\begin{array}{r}\Phi^{a} \\
{[\%]}\end{array}$ & $\begin{array}{l}\Phi_{\mathrm{F}}^{b} \\
{[\%]}\end{array}$ & $\begin{array}{c}\Phi_{\text {TADF }}{ }^{c} \\
{[\%]}\end{array}$ & $\begin{array}{c}\tau_{\mathrm{F}}{ }^{d} \\
{[\mathrm{~ns}]}\end{array}$ & $\begin{array}{c}\tau_{\mathrm{TADF}}{ }^{e} \\
{[\mu \mathrm{s}]}\end{array}$ & $\begin{array}{c}k_{\mathrm{F}}{ }^{f} \\
{\left[10^{8} \mathrm{~s}^{-1}\right]}\end{array}$ & $\begin{array}{c}k_{\mathrm{IC}}{ }^{f} \\
{\left[10^{7} \mathrm{~S}^{-1}\right]}\end{array}$ & $\begin{array}{c}k_{\mathrm{ISC}}{ }^{f} \\
{\left[10^{6} \mathrm{~s}^{-1}\right]}\end{array}$ & $\begin{array}{c}k_{\mathrm{RISC}}{ }^{f} \\
{\left[10^{5} \mathrm{~S}^{-1}\right]}\end{array}$ \\
\hline V-DABNA-Mes & 80 & 76 & 4.1 & 7.0 & 2.4 & 1.1 & 2.7 & 7.3 & 4.4 \\
\hline$v$-DABNA $g$ & 90 & 82 & 8 & 4.1 & 4.1 & 2.0 & 2.2 & 23 & 2.0 \\
\hline
\end{tabular}

${ }^{a}$ Absolute photoluminescence quantum yield. ${ }^{b}$ Quantum yield of fluorescent (prompt) component. c $Q$ uantum yield of TADF (delay) component. QLifetime of fluorescent (prompt) component. eLifetime of TADF (delay) component. ${ }^{f} k_{\mathrm{F}}, k_{\mathrm{IC}}, k_{\mathrm{ISC}}, k_{\mathrm{RISC}}$ are rate constants for fluorescence, internal conversion, intersystem crossing and reverse intersystem crossing, respectively. gref [9].

(9) Kondo, Y.; Yoshiura, K.; Kitera, S.; Nishi, H.; Oda, S.; Gotoh, H.; Sasada, Y.; Yanai, M.; Hatakeyama, T. Nat. Photonics 2019, 13, 678-682. 
Scheme S1. Synthesis of 1.
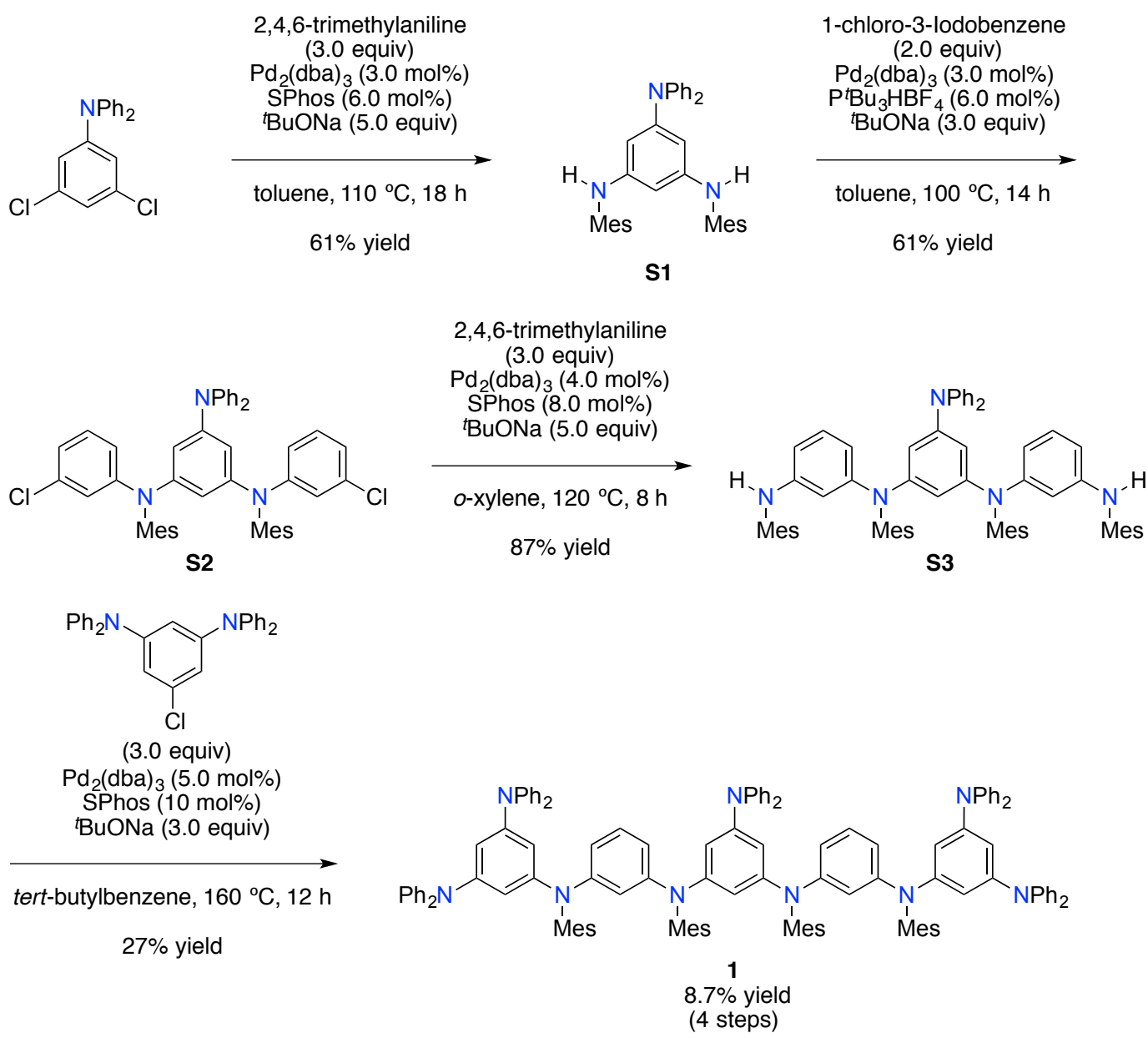

\section{Synthesis of $N^{1}, N^{3}$-dimesityl- $N^{5}, N^{5}$-diphenylbenzene-1,3,5-triamine (S1)}

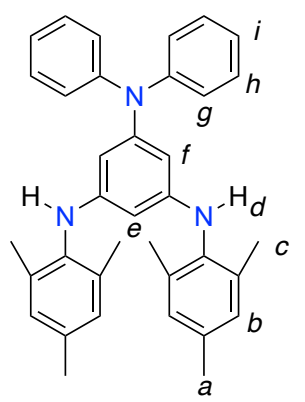

2,4,6-Trimethylaniline (16.9 $\mathrm{mL}, \quad 0.12 \mathrm{~mol})$ was added to a mixture of 3,5-dichloro- $N, N$-diphenylaniline (12.6 g, $40 \mathrm{mmol})$, sodium tert-butoxide (19.2 g, $0.20 \mathrm{~mol})$, SPhos (0.328 g, $0.80 \mathrm{mmol})$, tris(dibenzylideneacetone)dipalladium(0) (0.366 g, $0.40 \mathrm{mmol})$ in toluene $(400 \mathrm{~mL})$ under a nitrogen atmosphere. After stirring at $110{ }^{\circ} \mathrm{C}$ for $12 \mathrm{~h}$, the reaction mixture was allowed to cool to room temperature. After addition of aqueous $1 N$ hydrochloric acid $(50 \mathrm{~mL})$, the aqueous layer was separated, basified by saturated sodium carbonate aqueous solution $(150 \mathrm{~mL})$ and extracted with toluene $(200 \mathrm{~mL}$, three times). After the solvent was removed in vacuo, the crude product was purified by silica gel column chromatography (eluent: hexane/ethyl acetate $=8 / 1)$ to obtain the title compound $(12.5 \mathrm{~g}, 61 \%$ yield, $97 \%$ pure on NMR analysis $)$ as a 
white solid. IR (neat): $\mathrm{cm}^{-1} 3387$ (Ar-H), 3026, 2924, 1717, 1584, 1491, 1288, 1244, 1177, 1030, 856, 818, 748, 692; mp: 165.0-166.0 ${ }^{\circ} \mathrm{C},{ }^{1} \mathrm{H}$ NMR $\left(\mathrm{CDCl}_{3}, 400 \mathrm{MHz}\right) \delta 2.13$ (s, 12H, c), 2.24 (s, $6 \mathrm{H}, a), 4.86(\mathrm{~s}, 2 \mathrm{H}, d), 5.38(\mathrm{t}, J=2.0 \mathrm{~Hz}, 1 \mathrm{H}, e), 5.61(\mathrm{~d}, J=2.4 \mathrm{~Hz}, 2 \mathrm{H}, f), 6.82(\mathrm{~s}, 4 \mathrm{H}, b), 6.91(\mathrm{t}$, $J=7.2 \mathrm{~Hz}, 2 \mathrm{H} i), 7.04(\mathrm{~d}, J=7.6 \mathrm{~Hz}, 4 \mathrm{H}, g), 7.17(\mathrm{t}, J=7.6 \mathrm{~Hz}, 4 \mathrm{H}, i) ;{ }^{13} \mathrm{C} \mathrm{NMR}\left(\mathrm{CDCl}_{3}, 101 \mathrm{MHz}\right)$ $\delta 18.3$ (4C), 20.8 (2C), 94.5 (1C), 101.2 (2C), 121.8 (2C), 123.7 (4C), 128.7 (4C), 129.0 (4C), 134.9 (2C), 135.6 (4C), 135.7 (2C), 147.8 (2C), 148.4 (2C), 149.3 (1C); HRMS (MALDI-TOF/MS) $m / z[\mathrm{M}]^{+}$calcd for $\mathrm{C}_{36} \mathrm{H}_{37} \mathrm{~N}_{3} 511.2982$, observed 511.2970.

\section{Synthesis of $N^{1}, N^{3}$-bis(3-chlorophenyl)- $N^{1}, N^{3}$-dimesityl- $N^{5}, N^{5}$-diphenylbenzene-1,3,5-triamine} (S2)

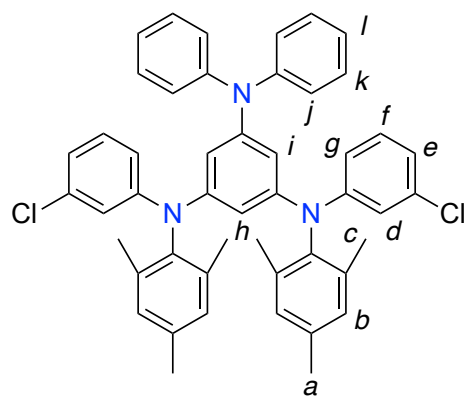

3-Chloroiodobenzene (4.94 mL, $40 \mathrm{mmol}$ ) was added to a mixture of $\mathbf{S 1}$ (10.2 g, $20 \mathrm{mmol})$, sodium tert-butoxide $(5.77 \mathrm{~g}, 60 \mathrm{mmol})$, tri-tert-butylphosphonium tetrafluoroborate $(0.348 \mathrm{~g}, 1.2 \mathrm{mmol})$, tris(dibenzylideneacetone)dipalladium $(0)(0.549 \mathrm{~g}, 0.60 \mathrm{mmol})$ in toluene $(200 \mathrm{~mL})$ under a nitrogen atmosphere. After stirring at $80{ }^{\circ} \mathrm{C}$ for $14 \mathrm{~h}$, the reaction mixture was allowed to cool to room temperature. After addition of aqueous $1 N$ hydrochloric acid $(45 \mathrm{~mL})$, the aqueous layer was separated, basified by saturated sodium carbonate aqueous solution $(75 \mathrm{~mL})$ and extracted with dichloromethane $(60 \mathrm{~mL}$, three times). After the solvent was removed in vacuo, the crude product was purified by silica gel column chromatography (eluent: hexane/dichloromethane $=8 / 1$ ) to obtain the title compound ( $9.90 \mathrm{~g}, 61 \%$ yield, 97\% pure on NMR analysis) as a white solid. IR (neat): $\mathrm{cm}^{-}$ 13013 (Ar-H), 2922, 1578, 1493, 1456, 1290, 1242, 1163, 1094, 1028, 991, 852, 775, 750, 691; mp: 208.0-209.5 ${ }^{\circ} \mathrm{C},{ }^{1} \mathrm{H} \mathrm{NMR}\left(\mathrm{CDCl}_{3}, 400 \mathrm{MHz}\right) \delta 1.90(\mathrm{~s}, 12 \mathrm{H}, c), 2.26(\mathrm{~s}, 6 \mathrm{H}, a), 6.15(\mathrm{t}, J=2.0$ $\mathrm{Hz}, 1 \mathrm{H}, h), 6.23(\mathrm{~d}, J=2.0 \mathrm{~Hz}, 2 \mathrm{H}, i), 6.64(\mathrm{dd}, J=1.6,8.0 \mathrm{~Hz}, 2 \mathrm{H}, g), 6.71(\mathrm{dd}, J=1.2,7.6 \mathrm{~Hz}$, $2 \mathrm{H}, e), 6.81(\mathrm{~s}, 4 \mathrm{H}, b), 6.83(\mathrm{t}, J=2.0 \mathrm{~Hz}, 2 \mathrm{H}, d), 6.91-7.02(\mathrm{~m}, 8 \mathrm{H}, f, j, l), 7.17(\mathrm{t}, J=7.8 \mathrm{~Hz}, 4 \mathrm{H}$, k); ${ }^{13} \mathrm{C}$ NMR $\left(\mathrm{CDCl}_{3}, 101 \mathrm{MHz}\right) \delta 18.2$ (4C), 20.9 (2C), 107.4 (1C), 109.6 (2C), 116.5 (2C), 118.1 (2C), 120.0 (2C), 122.6 (2C), 123.9 (4C), 129.0 (4C), 129.8 (6C), 134.6 (2C), 136.9 (2C), 137.0 (4C), 139.1 (2C), 146.3 (2C), 147.1 (2C), 147.2 (2C), 148.9 (1C); HRMS (MALDI-TOF/MS) m/z $[\mathrm{M}]^{+}$calcd for $\mathrm{C}_{48} \mathrm{H}_{43} \mathrm{Cl}_{2} \mathrm{~N}_{3} 731.2829$, observed 731.2817 . 


\section{Synthesis of $N^{1}, N^{3}$-dimesityl- $N^{1}, N^{3}$-bis(3-(mesitylamino)phenyl)- $N^{5}, N^{5}$-diphenylbenzene-}

\section{1,3,5-triamine (S3)}

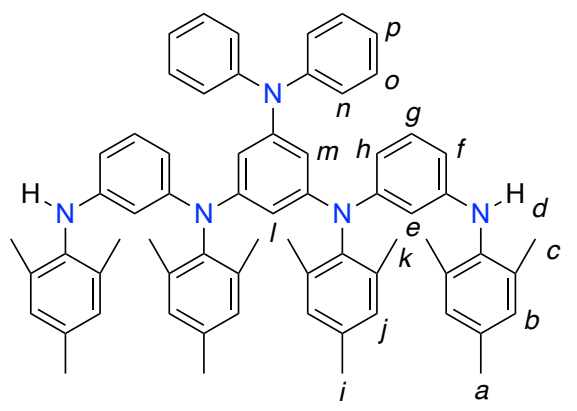

2,4,6-Trimethylaniline $(4.18 \mathrm{~mL}, 30 \mathrm{mmol})$ was added to a mixture of $\mathbf{S 2}$ (7.33 $\mathrm{g}, 10 \mathrm{mmol})$, sodium tert-butoxide $(4.81 \mathrm{~g}, 50 \mathrm{mmol})$, SPhos $(0.328 \quad \mathrm{~g}, \quad 0.80 \quad \mathrm{mmol})$, tris(dibenzylideneacetone)dipalladium $(0)(0.366 \mathrm{~g}, 0.40 \mathrm{mmol})$ in $o$-xylene $(100 \mathrm{~mL})$ under a nitrogen atmosphere. After stirring at $120{ }^{\circ} \mathrm{C}$ for $8 \mathrm{~h}$, the reaction mixture was allowed to cool to room temperature. After addition of aqueous $1 N$ hydrochloric acid $(15 \mathrm{~mL})$, the aqueous layer was separated, basified by saturated sodium carbonate aqueous solution (40 mL) and extracted with dichloromethane $(80 \mathrm{~mL}$, three times). After the solvent was removed in vacuo, the crude product was purified by silica gel column chromatography (eluent: hexane/ethylacetate $=20 / 1$ ) to obtain the title compound $\left(8.01 \mathrm{~g}, 87 \%\right.$ yield, $97 \%$ pure on NMR analysis) as a white solid. IR (neat): $\mathrm{cm}^{-1}$ $3404(\mathrm{~N}-\mathrm{H}), 3030$ (Ar-H), 2916, 1578, 1489, 1456, 1439, 1288, 1238, 1163, 1030, 849, 752, 692; mp: 262.0-265.5 ${ }^{\circ} \mathrm{C},{ }^{1} \mathrm{H}$ NMR $\left(\mathrm{CDCl}_{3}, 400 \mathrm{MHz}\right) \delta 1.87(\mathrm{~s}, 12 \mathrm{H}, c), 2.26(\mathrm{~s}, 12 \mathrm{H}, k), 2.23-2.27$ (m, $12 \mathrm{H}, a, i), 4.78(\mathrm{~s}, 2 \mathrm{H}, d), 5.73(\mathrm{dd}, J=1.6,8.0 \mathrm{~Hz}, 2 \mathrm{H}, h), 5.90(\mathrm{t}, J=2.0 \mathrm{~Hz}, 1 \mathrm{H}, l), 6.08(\mathrm{dd}, J=$ 1.6, $8.0 \mathrm{~Hz}, 2 \mathrm{H}, f), 6.23(\mathrm{t}, J=1.6 \mathrm{~Hz}, 2 \mathrm{H}, e), 6.41(\mathrm{~d}, J=1.6 \mathrm{~Hz}, 2 \mathrm{H}, m), 6.72-6.78(\mathrm{~m}, 6 \mathrm{H}, b, g)$, 6.86-6.91 (m, 6H, $j, p), 7.02(\mathrm{~d}, J=7.6 \mathrm{~Hz}, 4 \mathrm{H} n), 7.16(\mathrm{t}, J=7.8 \mathrm{~Hz}, 4 \mathrm{H}, o) ;{ }^{13} \mathrm{C} \mathrm{NMR}\left(\mathrm{CDCl}_{3}\right.$, $101 \mathrm{MHz}) \delta 18.2$ (8C), 20.9 (4C), 104.2 (2C), 105.2 (2C), 108.0 (1C), 109.1 (2C), 109.8 (2C), 121.9 (2C), 123.3 (4C), 128.8 (4C), 129.0 (4C), 129.3 (6C), 135.0 (2C), 135.8 (6C), 136.0 (2C), 137.1 (4C), 140.0 (2C), 146.5 (2C), 146.9 (2C), 147.2 (2C), 147.7 (2C), 148.2 (1C); HRMS (MALDI-TOF/MS) $m / z[\mathrm{M}]^{+}$calcd for $\mathrm{C}_{66} \mathrm{H}_{67} \mathrm{~N}_{5}$ 929.5391, observed 929.5419.

\section{Synthesis of $N^{1}, N^{1}$-(((5-diphenylamino)-1,3-phenylene)bis(mesitylazanediyl))bis}

\section{(3,1-phenylene))bis( $N^{1}$-mesityl- $N^{3}, N^{3}, N^{5}, N^{5}$-tetraphenylbenzene-1,3,5-triamine (1)}

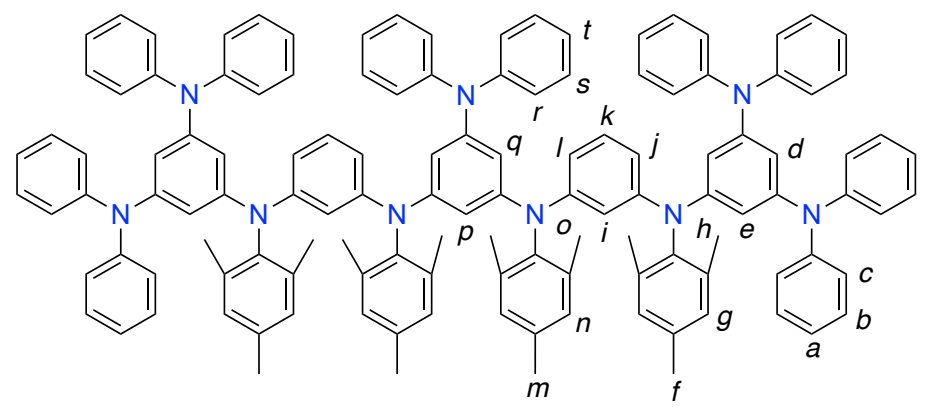

Tris(dibenzylideneacetone)dipalladium(0) (0.114 g, $0.13 \mathrm{mmol})$, SPhos (0.103 g, $0.25 \mathrm{mmol}), \mathbf{S 3}$ 
(2.33 g, $2.5 \mathrm{mmol}$ ), 5-chloro- $N^{1}, N^{1}, N^{3}, N^{3}$-tetraphenylbenzene-1,3-diamine (3.35 g, $\left.7.5 \mathrm{mmol}\right)$, and sodium tert-butoxide $(1.20 \mathrm{~g}, 13 \mathrm{mmol})$ were dissolved in tert-butylbenzene $(25 \mathrm{~mL})$ under a nitrogen atmosphere. After stirring at $160{ }^{\circ} \mathrm{C}$ for $16 \mathrm{~h}$, the reaction mixture was allowed to cool to room temperature. After addition of aqueous $1 N$ hydrochloric acid $(30 \mathrm{~mL})$, the aqueous layer was separated, basified by saturated sodium carbonate aqueous solution $(60 \mathrm{~mL})$ and extracted with dichloromethane $(80 \mathrm{~mL}$, three times). After the solvent was removed in vacuo, the crude product was purified by silica gel column chromatography (eluent: hexane/dichloromethane $=1 / 1$ ) to obtain the title compound (1.21 g, 28\% yield, 97\% pure on NMR analysis) as a white solid. IR (neat): $\mathrm{cm}^{-}$ 13024 (Ar-H), 2911, 1568, 1493, 1456, 1287, 1240, 1034, 849, 748, 692; mp: >300 ${ }^{\circ} \mathrm{C},{ }^{1} \mathrm{H}$ NMR $\left(\mathrm{CDCl}_{3}, 400 \mathrm{MHz}\right) \delta 1.65(\mathrm{~s}, 12 \mathrm{H}, o), 1.72(\mathrm{~s}, 12 \mathrm{H}, h), 2.17-2.19(\mathrm{~m}, 12 \mathrm{H}, f, m), 5.82(\mathrm{~s}, 1 \mathrm{H}, i)$, 6.18-6.20 (m, 10H, e, $l, j, q), 6.25(\mathrm{~s}, 2 \mathrm{H}, i), 6.36(\mathrm{~s}, 2 \mathrm{H}, d), 6.61-6.63(\mathrm{~m}, 8 \mathrm{H}, g, n), 6.69(\mathrm{t}, J=$ $8.2 \mathrm{~Hz}, 2 \mathrm{H}, k), 6.83-6.87(\mathrm{~m}, 10 \mathrm{H}, a, t), 6.92-6.95(\mathrm{~m}, 20 \mathrm{H}, c, r), 7.06-7.11(\mathrm{~m}, 20 \mathrm{H}, b, s) ;{ }^{13} \mathrm{C}$ NMR (CDCl $3,101 \mathrm{MHz}) \delta 18.0$ (4C), 18.1 (4C), 20.9 (4C), 107.5 (1C), 109.2 (2C), 109.5 (2C), 110.9 (4C), 111.4 (2C), 113.0 (2C), 122.0 (2C), 122.2 (8C), 123.3 (4C), 123.5 (16C), 128.8 (24C), 129.2 (4C), 129.5 (4C), 135.8 (2C), 136.0 (2C), 136.8 (8C), 139.8 (2C), 139.9 (2C), 145.8 (2C), 146.0 (2C), 146.8 (2C), 147.3 (10C), 147.4 (2C), 148.0 (1C), 148.5 (4C); HRMS (MALDI-TOF/MS) $m / z[\mathrm{M}]^{+}$calcd for $\mathrm{C}_{126} \mathrm{H}_{111} \mathrm{~N}_{9} 1750.8989$, observed 1750.8988 .

Synthesis of $9,11,15,17-$ tetramesityl- $N^{7}, N^{7}, N^{13}, N^{13}, N^{19}, N^{19}, 5,21-o c t a p h e n y l-5,9,11,15,17,21-$ hexahydro-5,9,11,15,17,21-hexaaza-25b,26b,27b-triboranaphtho[3,2,1-de]naphtho $\left[3^{\prime}, 2^{\prime}, 1^{\prime}: 10,11\right]$ tetraceno[1,2,3-jk]pentacene-7,13,19-triamine (V-DABNA-Mes)

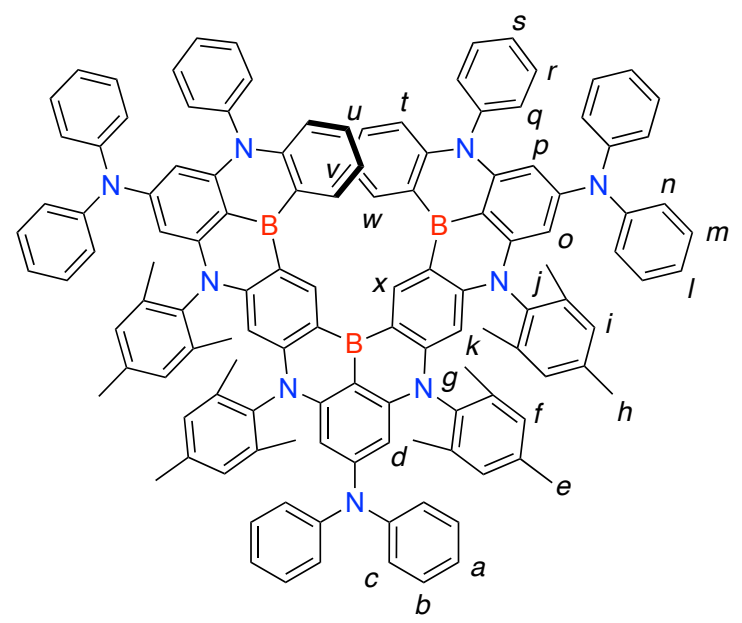

To $50 \mathrm{~mL}$ autoclave were added boron tribromide (1.52 mL, $16 \mathrm{mmol}), 1$ (0.876 g, $0.50 \mathrm{mmol})$ in 1,2-dichlorobenzene $(10 \mathrm{~mL})$ at room temperature under a nitrogen atmosphere. After stirring at $180{ }^{\circ} \mathrm{C}$ for $20 \mathrm{~h}$, the reaction mixture was allowed to cool to room temperature. After phosphorus buffer solution $(\mathrm{pH}=7,50 \mathrm{~mL})$ was added to the reaction mixture at $0{ }^{\circ} \mathrm{C}$, the aqueous layer was separated and extracted with dichloromethane $(200 \mathrm{~mL}$, three times). After the solvent was removed in vacuo, the crude product was purified by silica gel column chromatography (eluent: 
hexane/dichloromethane $=2 / 3)$ to obtain the title compound $(0.393 \mathrm{~g}, 44 \%$ yield, $97 \%$ pure on NMR analysis) as a yellow solid. IR (neat): $\mathrm{cm}^{-1} 3030$ (Ar-H), 2918, 1578, 1489, 1429, 1260, 1163, 1072, 1026, 822, 752, 696; mp: $>300{ }^{\circ} \mathrm{C},{ }^{1} \mathrm{H} \mathrm{NMR}\left(\mathrm{CDCl}_{3}, 400 \mathrm{MHz}\right) \delta 1.73(\mathrm{~m}, 24 \mathrm{H}, g, j), 2.23$ $(\mathrm{m}, 12 \mathrm{H}, e, h), 5.67-5.68(\mathrm{~m}, 6 \mathrm{H}, d, o, p), 5.72(\mathrm{~s}, 2 \mathrm{H}, k), 6.36(\mathrm{t}, J=7.4 \mathrm{~Hz}, 2 \mathrm{H}, v), 6.49(\mathrm{~d}, J=$ $8.4 \mathrm{~Hz}, 2 \mathrm{H}, t), 6.67$ (m, 8H, f, i), 6.84-6.94 (m, 20H, a, c, l, n, u), 7.03-7.08 (m, 12H, b, m), 7.27 (d, $J=7.2 \mathrm{~Hz}, 4 \mathrm{H}, q), 7.34(\mathrm{t}, J=7.6 \mathrm{~Hz}, 2 \mathrm{H}, s), 7.45(\mathrm{t}, J=7.6 \mathrm{~Hz}, 4 \mathrm{H}, r), 9.08(\mathrm{~d}, J=7.6 \mathrm{~Hz}, 2 \mathrm{H}, w)$, 10.7 (s, 2H, $x$ ); ${ }^{13} \mathrm{C} \mathrm{NMR}\left(\mathrm{CDCl}_{3}, 126 \mathrm{MHz}\right) \delta 17.2$ (4C), 17.3 (4C), 21.0 (4C), 98.3 (2C), 99.3 (2C), 99.5 (2C), 100.1 (2C), 115.9 (2C), 120.1 (2C), 122.5 (2C), 122.8 (4C), 124.4 (4C), 124.8 (8C), 128.0 (2C), 128.5 (4C), 128.6 (8C), 129.1 (4C), 129.2 (4C), 130.2 (2C), 130.3 (4C), 130.5 (4C), 135.7 (2C), 136.2 (4C), 136.3 (8C), 137.0 (4C), 142.5 (2C), 144.3 (2C), 146.2 (2C), 146.4 (2C), 147.0 (4C), 147.1 (2C), 147.4 (2C), 148.1 (2C), 148.8 (4C), 151.3 (2C), 151.6 (1C). The NMR signal of the carbon $\alpha$ to the boron was not observed.; ${ }^{11} \mathrm{~B} \mathrm{NMR}\left(160 \mathrm{MHz}, \mathrm{CDCl}_{3}\right.$, $\delta 39.3$; HRMS (MALDI-TOF/MS) $m / z[\mathrm{M}]^{+}$calcd for $\mathrm{C}_{126} \mathrm{H}_{102} \mathrm{~B}_{3} \mathrm{~N}_{9}$ 1773.8576, observed 1773.8574 .

\section{Synthetic procedure under standard reflux conditions in a flask (eq. S1)}

To $5.0 \mathrm{~mL}$ flask were added boron tribromide $(0.151 \mathrm{~mL}, 1.6 \mathrm{mmol}), 1(87.6 \mathrm{mg}, 0.050 \mathrm{mmol})$ in 1,2-dichlorobenzene $(1.0 \mathrm{~mL})$ at room temperature under a nitrogen atmosphere. After stirring at $200{ }^{\circ} \mathrm{C}$ for $18 \mathrm{~h}$, the reaction mixture was allowed to cool to room temperature. After phosphorus buffer solution $(\mathrm{pH}=7,5.0 \mathrm{~mL})$ was added to the reaction mixture at $0{ }^{\circ} \mathrm{C}$, the aqueous layer was separated and extracted with dichloromethane $(20 \mathrm{~mL}$, three times). Acetic acid $(57.2 \mu \mathrm{L}, 1.0$ mmol) was added to the crude product in 1,2-dichlorobenzene $(1.0 \mathrm{~mL})$ at room temperature. After stirring at $100{ }^{\circ} \mathrm{C}$ for $2 \mathrm{~h}$, saturated sodium carbonate $(10 \mathrm{~mL})$ was added to the reaction mixture, and then the aqueous layer was extracted with dichloromethane (20 mL, three times). The combined organic layers were concentrated in vacuo, the yield of the title compound in the crude product was determined to be $3 \%$ by ${ }^{1} \mathrm{H}$ NMR using 1,1,2,2-tetrachloroethane as an internal standard.
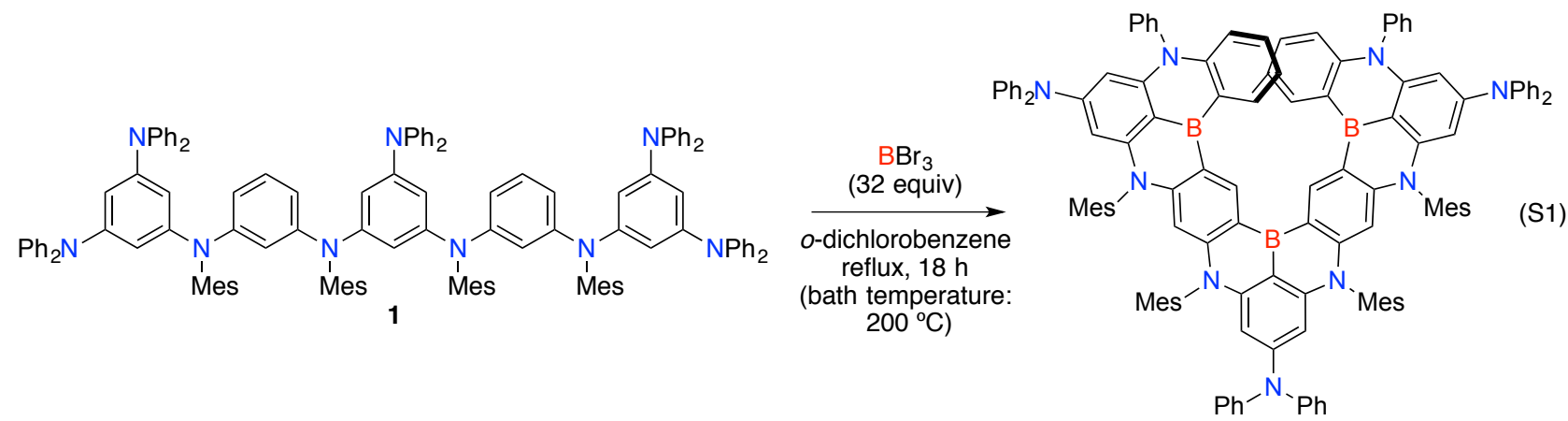

V-DABNA-Mes

$3 \%$ yield (NMR) 
Scheme S2. Synthesis of polymers A and C by Suzuki-Miyaura coupling.

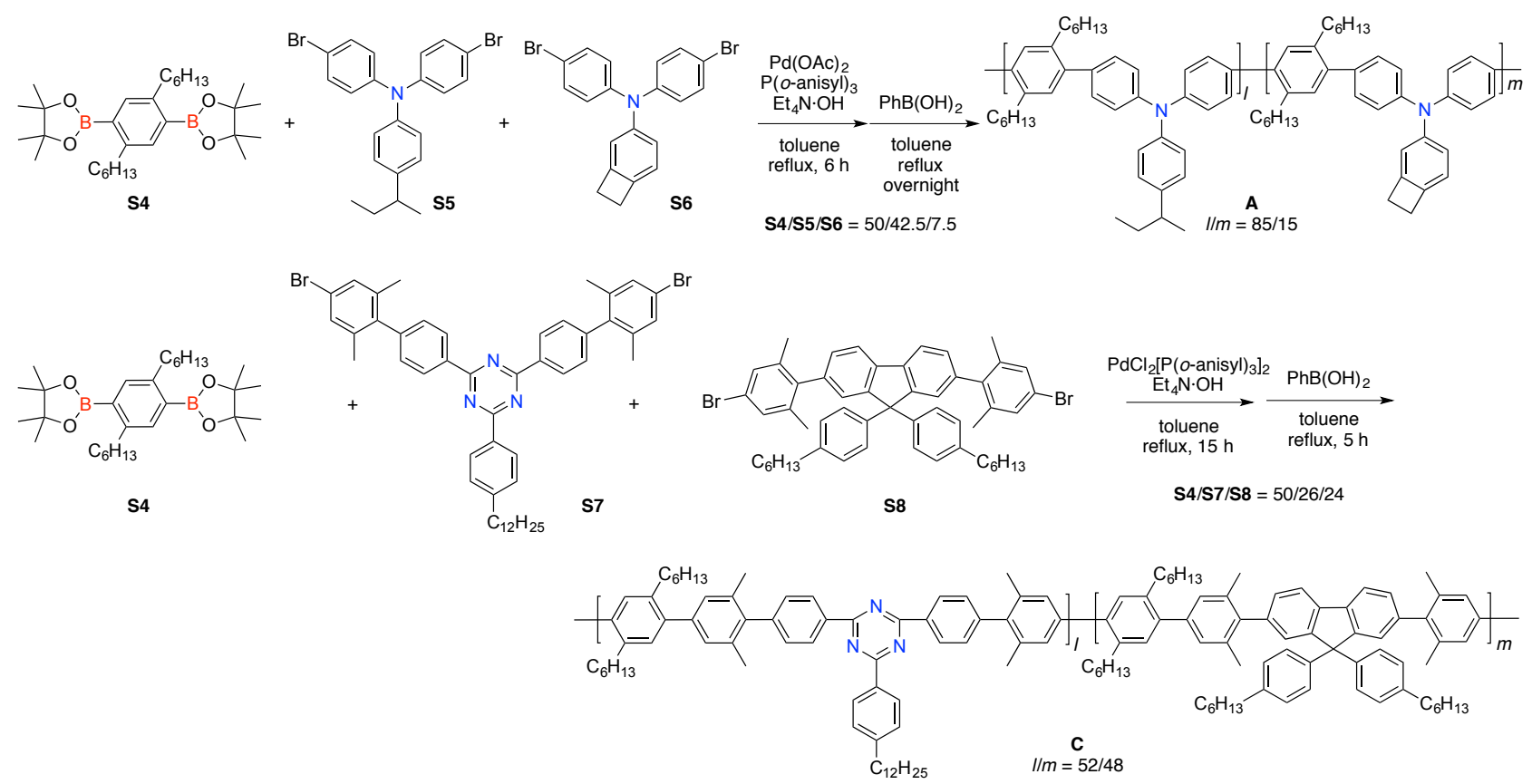

\section{Synthesis of polymer A}

Polymer A was prepared according to the reported procedure ${ }^{10}$.

\section{Synthesis of polymer C}

After the inside of the reaction vessel was set to a nitrogen atmosphere, 2,2'-(2,5-dihexyl-1,4-phenylene)bis(4,4,5,5-tetramethyl-1,3,2-dioxaborolane) (S4) (6.48 g, 13.28 mmol), 2,4-bis(4'-bromo-2',6'-dimethyl[1,1'-biphenyl]-4-yl)-6-(4-dodecylphenyl)-1,3,5-triazine (S5) $\quad(5.89 \mathrm{~g}, \quad 6.90 \mathrm{mmol}), \quad$ 2,7-bis(4-bromo-2,6-dimethylphenyl)-9,9-bis(4-hexylphenyl) -9H-fluorene (S6) (5.38 g, $6.37 \mathrm{mmol}$ ), dichlorobis(tri-o-methoxyphenylphosphine)palladium(II) $(11.7 \mathrm{mg}, 13.3 \mu \mathrm{mol})$, and $10 \mathrm{wt} \%$ tetraethylammonium hydroxide $(120 \mathrm{~g}, 81.5 \mathrm{mmol})$ were dissolved in toluene $(170 \mathrm{~mL})$, and the mixture was stirred under reflux for 15 hours. Phenylboronic acid $(0.647 \mathrm{~g}, 5.3 \mathrm{mmol})$ was added, and the mixture was stirred under reflux for 5hours. Then, the oil layer was separated from the aqueous layer, washed with water, $10 \mathrm{wt} \%$ hydrochloric acid aqueous solution and $3 \mathrm{wt} \%$ ammonia aqueous solution and passed through an alumina column and a silica gel column. The obtained oil layer was dropped into methanol to obtain a precipitate. The precipitate was filtered, washed with methanol, and dried under reduced pressure to obtain the title compound having a number average molecular weight $\mathrm{Mn}=1.1 \times 10^{5}$ and a weight average molecular weight $\mathrm{Mw}=2.5 \times 10^{5}$.

(10) Ikeda, N.; Oda, S.; Matsumoto, R.; Yoshioka, M.; Fukushima, D.; Yoshiura, K.; Hatakeyama, T. Adv. Mater. 2020, 32, 2004072. 
The number average molecular weight $(\mathrm{Mn})$ in terms of polystyrene and the weight average molecular weight $(\mathrm{Mw})$ in terms of polystyrene of the polymer compound were determined by the following size exclusion chromatography (SEC) using tetrahydrofuran as a mobile phase. The polymer compound to be measured was dissolved in tetrahydrofuran at a concentration of about $0.05 \%$ by weight, and $10 \mu \mathrm{L}$ was injected into SEC. The mobile phase was flowed at a flow rate of 1.0 mL / min. PLgel @ MIXED-B (manufactured by Polymer Laboratories) was used as a column. A UV-VIS detector (manufactured by Tosoh, trade name: UV-8320GPC) was used as the detector. 
Crystallographic Data Collection and Structure Determination. The crystal data of V-DABNA-Mes was collected on a Rigaku Mercury375R/M CCD (XtaLAB mini) diffractometer using curved graphite monochromated Mo K $\alpha$ radiation $(\lambda=0.71075 \AA)$. The reflection data for V-DABNA-Mes was integrated, scaled, and averaged by using Rigaku CrystalClear. The structures were solved by a direct method (SIR2004 ${ }^{11}$ ) and refined by full-matrix least square method on $F^{2}$ for all reflections (SHELXL-97'12). All hydrogen atoms were placed using AFIX instructions (C-H $=0.95 \AA$ ), while all other atoms were refined anisotropically. In the subsequent refinement, the function $\sum w\left(F_{\mathrm{o}}^{2}-F_{\mathrm{c}}^{2}\right)^{2}$ was minimized, oc where $\left|F_{\mathrm{o}}\right|$ and $\left|F_{\mathrm{c}}\right|$ are the observed and calculated structure factor amplitudes, respectively. The agreement indices are defined as $\mathrm{R}=\sum\left(|| F_{\mathrm{o}} \mid-\right.$ $\left.\left|F_{\mathrm{c}}\right|\right) / \sum\left|F_{\mathrm{o}}\right|$ and $w \mathrm{R}=\left[\sum w\left(F_{\mathrm{o}}{ }^{2}-F_{\mathrm{c}}{ }^{2}\right)^{2} / \sum\left(w F_{\mathrm{o}}{ }^{4}\right)\right] 1 / 2$. All calculations were performed by using Rigaku CrystalStructure 4.1 or Yadokari-XG 2009 and illustrations were drawn by using ORTEP-3.

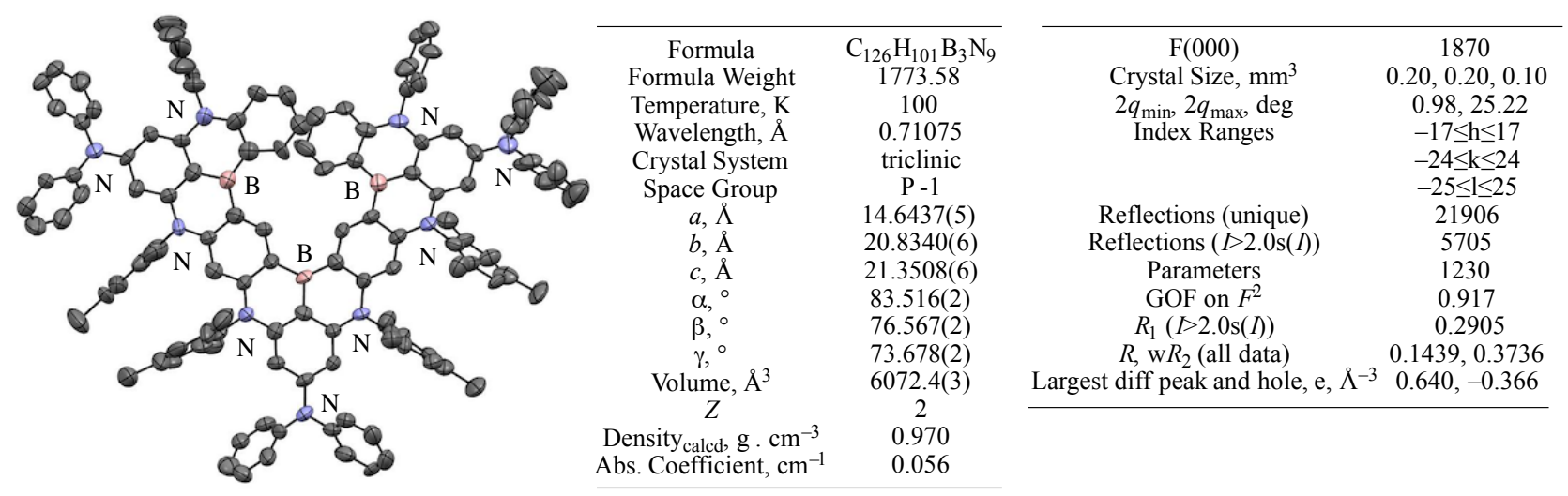

Figure S1. X-ray crystal structure of V-DABNA-Mes (left), and crystal data and structure refinement (right). Thermal ellipsoids are shown at 50\% probability; hydrogen atoms have been omitted for clarity.

(11) Burla, M. C.; Caliandro, R.; Camalli, M.; Carrozzini, B.; Cascarano, G. L.; De Caro, L.; Giacovazzo, C.; Polidori, G.; Siliqi, D.; Spagna, R. J. Appl. Cryst. 2007, 40, 609.

(12) Sheldrick, G. M. Program for the Solution of Crystal Structures; University of Göttingen, Germany, 1997. 


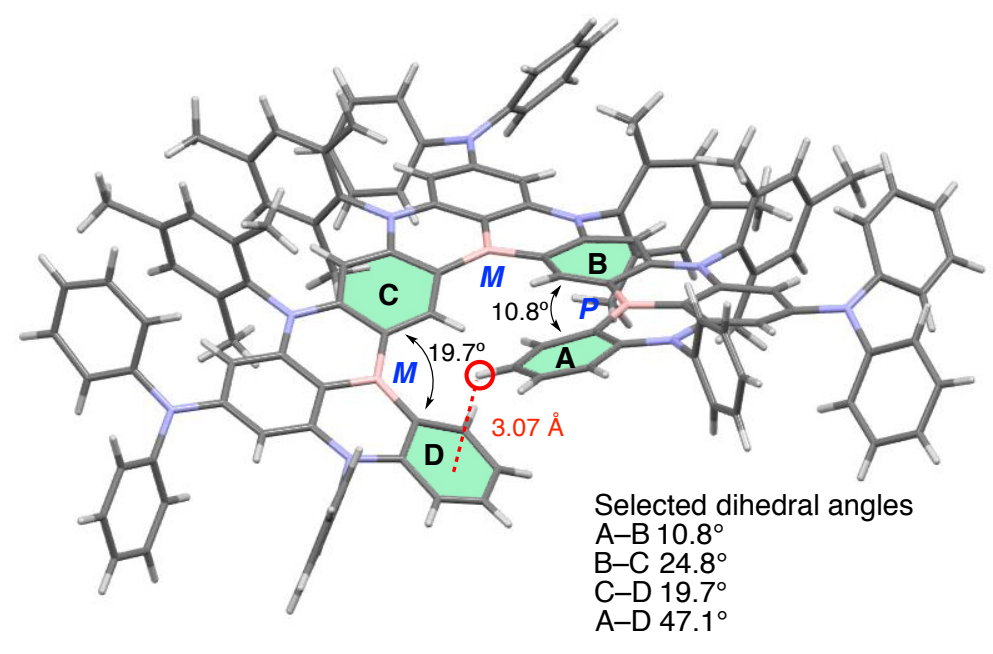

Figure S2. Molecular structure of V-DABNA-Mes determined by single-crystal X-ray diffraction. The stereochemistry of [4]helicene subunits is shown in blue.
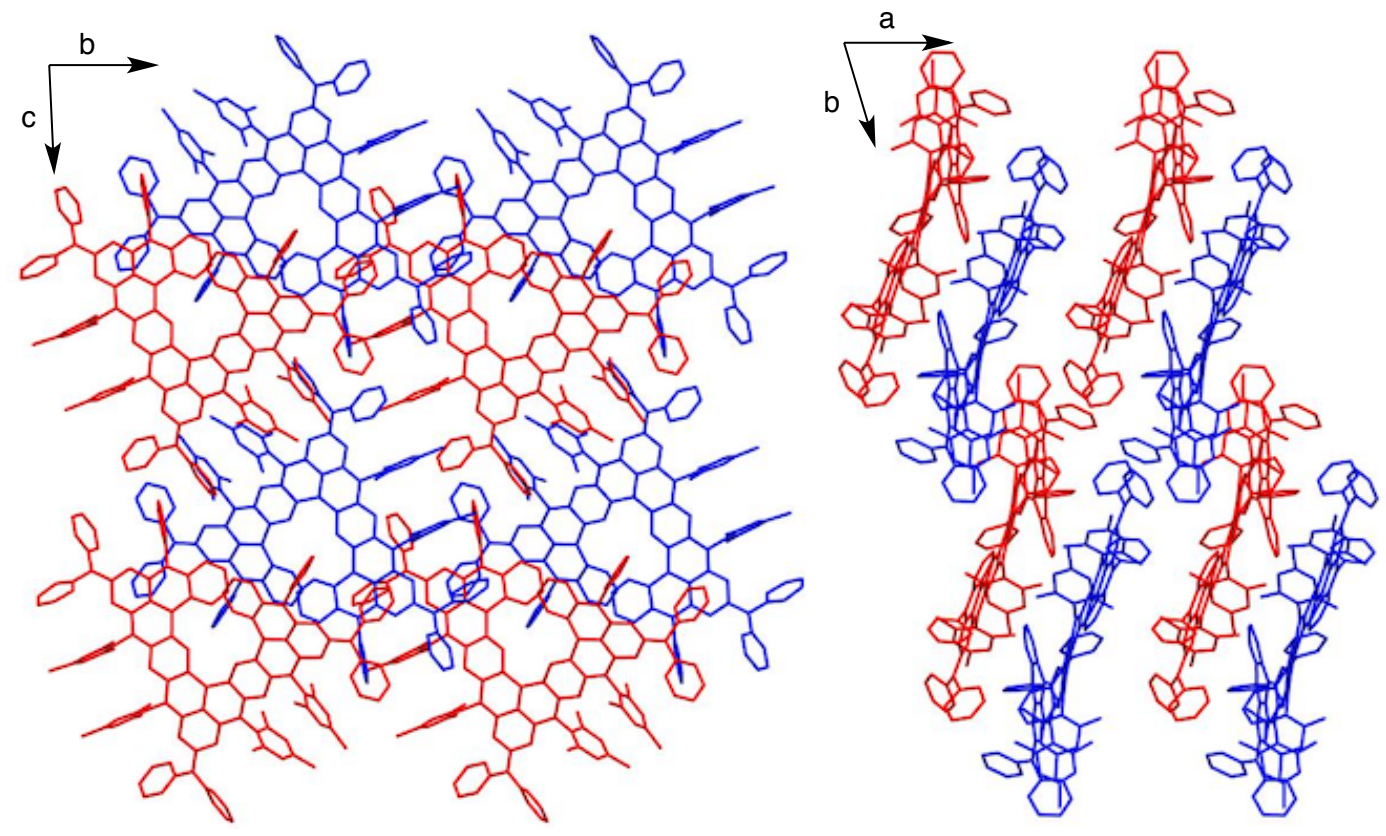

Figure S3. Packing structures of V-DABNA-Mes obtained by X-ray crystal analysis. Hydrogen atoms have been omitted for clarity. The $(P, M, M)$ enantiomer is shown in blue and the $(M, P, P)$ enantiomer in red. 


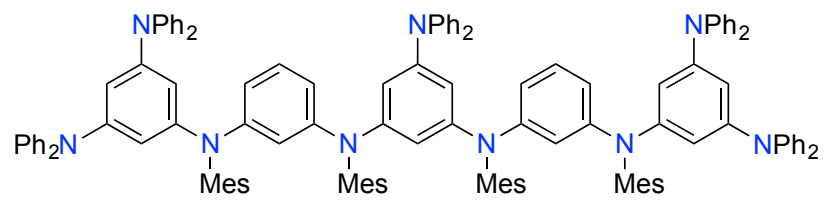

1

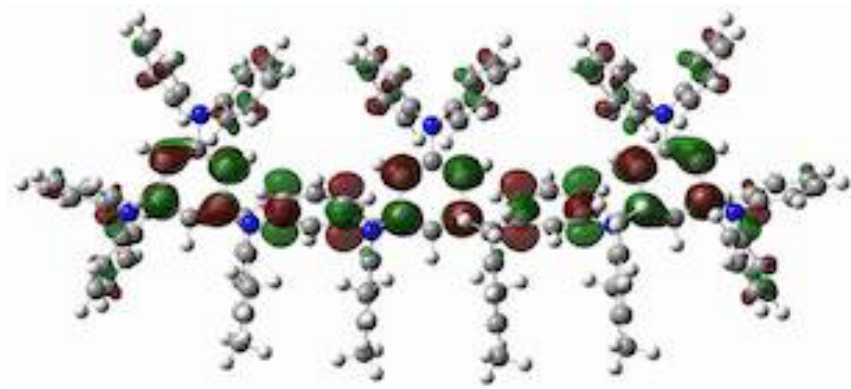

LUMO $(-0.45 \mathrm{eV})$

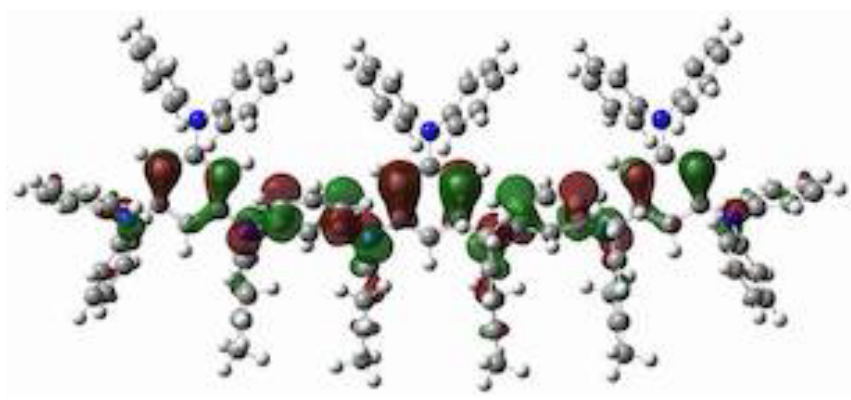

HOMO $(-4.67 \mathrm{eV})$
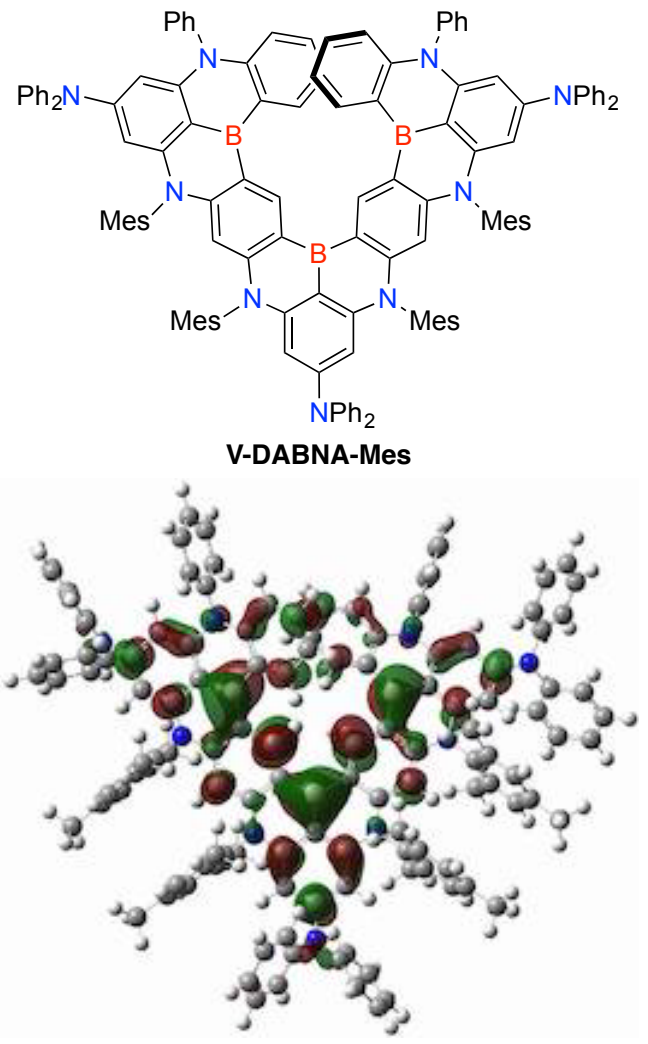

$\operatorname{LUMO}(-1.23 \mathrm{eV})$

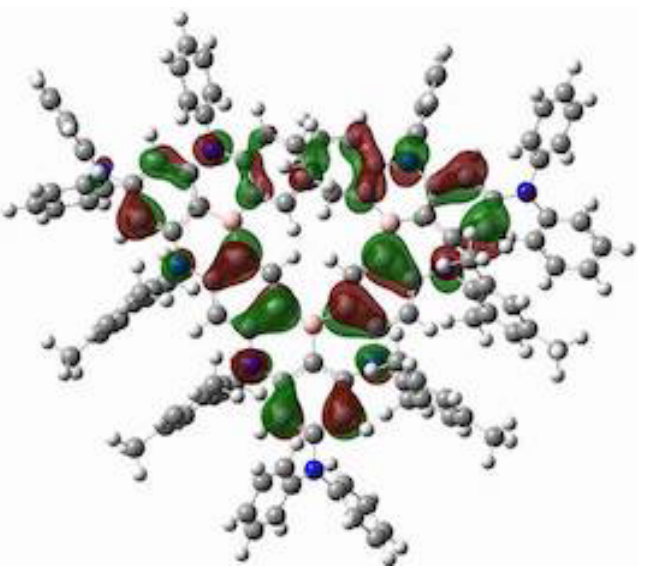

HOMO $(-4.47 \mathrm{eV})$

Figure S4. Kohn-Sham frontier orbitals of $\mathbf{1}$ and V-DABNA-Mes calculated at the B3LYP/6-31G(d) level of theory (Gaussian 09). 
Table S5. Summary of Electronic Energy $(E)$ and Relative Electronic Energy $(\Delta E)$ for V-NTP-core at the $\mathrm{S}_{0}, \mathrm{~S}_{1}, \mathrm{~T}_{1}$ and $\mathrm{T}_{2}$ Structures at the B3LYP/TZP Level of Theory (ADF2021).

\begin{tabular}{|c|c|c|c|c|}
\hline $\begin{array}{c}\text { Optimized } \\
\text { structure }\end{array}$ & $\begin{array}{c}E_{\mathrm{S} 0}(\text { A.U. }) \\
\Delta E_{\mathrm{S} 0}(\mathrm{meV})\end{array}$ & $\begin{array}{c}E_{\mathrm{S} 1}(\mathrm{~A} . \mathrm{U} .) \\
\Delta E_{\mathrm{S} 1}(\mathrm{meV})\end{array}$ & $\begin{array}{c}E_{\mathrm{T} 1} \text { (A.U.) } \\
\Delta E_{\mathrm{T} 1}(\mathrm{meV})\end{array}$ & \begin{tabular}{c}
$E_{\mathrm{T} 2}$ (A.U.) \\
\hline $\mathrm{S}_{0}$
\end{tabular}$E_{\mathrm{T} 2}(\mathrm{meV})$ \\
\hline $\mathrm{S}_{1}$ & -24.12298 & -24.01624 & -24.02517 & -24.02045 \\
& 0 & 29 & 30 & 30 \\
\hline $\mathrm{T}_{1}$ & -24.12193 & -24.01729 & -24.02626 & -24.02071 \\
& 33 & 0 & 0.2 & 22 \\
\hline $\mathrm{T}_{2}$ & -24.12156 & -24.01638 & -24.02544 & -24.01720 \\
& 39 & 25 & -24.02627 & 25 \\
\hline
\end{tabular}

Table S6. Summary of Electronic Energy $(E)$ and Relative Electronic Energy $(\Delta E)$ for v-DABNA-core at the $\mathrm{S}_{0}, \mathrm{~S}_{1}, \mathrm{~T}_{1}$ and $\mathrm{T}_{2}$ Structures at the B3LYP/TZP Level of Theory (ADF2021).

\begin{tabular}{|c|c|c|c|c|}
\hline $\begin{array}{c}\text { Optimized } \\
\text { structure }\end{array}$ & $\begin{array}{c}E_{\mathrm{S} 0}(\text { A.U. }) \\
\Delta E_{\mathrm{S} 0}(\mathrm{meV})\end{array}$ & $\begin{array}{c}E_{\mathrm{S} 1}(\text { A.U. }) \\
\Delta E_{\mathrm{S} 1}(\mathrm{meV})\end{array}$ & $\begin{array}{c}E_{\mathrm{T} 1} \text { (A.U.) } \\
\Delta E_{\mathrm{T} 1}(\mathrm{meV})\end{array}$ & $\begin{array}{c}E_{\mathrm{T} 2} \text { (A.U.) } \\
\Delta E_{\mathrm{T} 2}(\mathrm{meV})\end{array}$ \\
\hline $\mathrm{S}_{0}$ & -17.12287 & -17.01136 & -17.02421 & -17.01676 \\
& 0 & 39 & 43 & 74 \\
\hline $\mathrm{S}_{1}$ & -17.12116 & -17.01279 & -17.02571 & -17.01804 \\
\hline & 46 & 0 & 2 & 39 \\
\hline $\mathrm{T}_{1}$ & -17.12103 & -17.01267 & -17.02579 & -17.01765 \\
& 50 & 3 & 0 & 50 \\
\hline $\mathrm{T}_{2}$ & -17.11949 & -17.01114 & -17.02379 & -17.01949 \\
& 92 & 45 & 54 & 0 \\
\hline
\end{tabular}




\section{Spin-Orbit Coupling Calculations}

Using the optimized geometries in the ground state, the spin-orbit coupling (SOC) matrix elements $\left\langle S_{1}\left|\widehat{H}_{S O C}\right| T_{n}\right\rangle$ between $\mathrm{S}_{1}$ and $\mathrm{T}_{\mathrm{n}}(\mathrm{n}=1,2)$ were obtained performing TD-DFT calculations with the B3LYP functional and the TZP basis set as implemented in the ADF2021 program. Taking into account the contributions from the three degenerate triplet states $\left(\mathrm{T}_{\mathrm{n}, \mathrm{x}}, \mathrm{T}_{\mathrm{n}, \mathrm{y}}\right.$, and $\left.\mathrm{T}_{\mathrm{n}, \mathrm{z}}\right),\left\langle S_{1}\left|\widehat{H}_{S O C}\right| T_{n}\right\rangle$ were calculated by the root sum square of the real and imaginary parts (Re and $I m$ ) of the matrix elements (eq. S2).

$$
\left\langle S_{1}\left|\widehat{H}_{S O C}\right| T_{n}\right\rangle=\sum_{\alpha=x, y, z}\left[\left(\operatorname{Re}\left\langle S_{1}\left|\widehat{H}_{S O C}\right| T_{n, \alpha}\right\rangle\right)^{2}+\left(\operatorname{Im}\left\langle S_{1}\left|\widehat{H}_{S O C}\right| T_{n, \alpha}\right\rangle\right)^{2}\right]^{\frac{1}{2}}
$$




\section{Measurement of absorption and emission characteristics}

UV-visible absorption spectra were measured using a UV-2600 (Shimadzu) and a V-560 UV-visible spectrometer (JASCO) at $298 \mathrm{~K}$. Photoluminescence (PL) spectra were measured using a FluoroMax-4P (HORIBA) and a F-7000 (Hitachi High-Tech) at 77 and 298 K. Furthermore, the absolute PL quantum yields were measured using C11347 and C9920-02G spectrometers (Hamamatsu Photonics), whereas PL decays were measured using a C11367 spectrometer (298 K, Hamamatsu Photonics) and then fitted using a single exponential function to determine the lifetimes of prompt and delayed fluorescence.

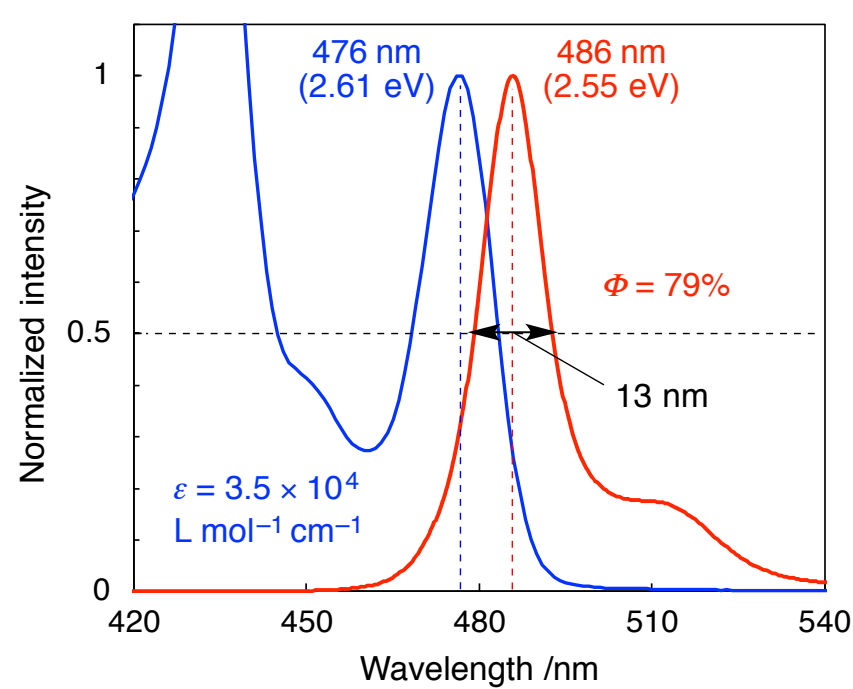

Figure S5. Normalized absorption (blue, $0.02 \mathrm{mM}$ in toluene), fluorescence (red, $0.02 \mathrm{mM}$ in toluene) spectra with absorption/emission maxima (nm, eV), absorption coefficient at an absorption maximum $(\varepsilon)$, absolute fluorescence quantum yield $(\Phi)$, and full width at half maximum (nm) of V-DABNA-Mes (excited at $365 \mathrm{~nm}$ ). 
Estimation of rate constant for reverse intersystem crossing. Rate constants $\left(k_{\mathrm{F}}, k_{\mathrm{IC}}, k_{\mathrm{ISC}}\right.$, and $\left.k_{\mathrm{RISC}}\right)$ were determined from the measurements of quantum yields ( $\Phi_{\mathrm{F}}$ and $\left.\Phi_{\mathrm{TADF}}\right)$ and lifetimes $\left(\tau_{\mathrm{F}}\right.$, $\left.\tau_{\mathrm{TADF}}\right)$ and of the prompt (fluorescence) and delayed (TADF) components according to Adachi's method (equations $1-2^{13}, 3-5^{14}$ and $6^{15}$ ).

$$
\begin{array}{ll}
\Phi=0.789 & \\
\Phi_{\mathrm{F}}=0.756 & \\
\Phi_{\mathrm{TADF}}=0.033 & \\
\tau_{\mathrm{F}}=6.72 \mathrm{~ns} & \\
\tau_{\mathrm{TADF}}=2.48 \mu \mathrm{s} & \\
k_{\mathrm{p}}=1.49 \times 10^{8} \mathrm{~s}^{-1} & k_{\mathrm{p}}=1 / \tau_{\mathrm{F}} \\
k_{\mathrm{d}}=4.03 \times 10^{5} \mathrm{~s}^{-1} & k_{\mathrm{d}}=1 / \tau_{\mathrm{TADF}} \\
k_{\mathrm{F}}=1.13 \times 10^{8} \mathrm{~s}^{-1} & k_{\mathrm{F}}=\Phi_{\mathrm{F}} / \tau_{\mathrm{F}} \\
k_{\mathrm{IC}}=3.01 \times 10^{6} \mathrm{~s}^{-1} & \Phi=k_{\mathrm{F}} /\left(k_{\mathrm{F}}+k_{\mathrm{IC}}\right) \\
k_{\mathrm{ISC}}=6.25 \times 10^{6} \mathrm{~s}^{-1} & \Phi_{\mathrm{F}}=k_{\mathrm{F}} /\left(k_{\mathrm{F}}+k_{\mathrm{IC}}+k_{\mathrm{ISC}}\right) \\
k_{\mathrm{RISC}}=4.22 \times 10^{5} \mathrm{~s}^{-1} & k_{\mathrm{RISC}}=k_{\mathrm{p}} k_{\mathrm{d}} /\left(k_{\mathrm{p}}-k_{\mathrm{ISC}}\right)
\end{array}
$$
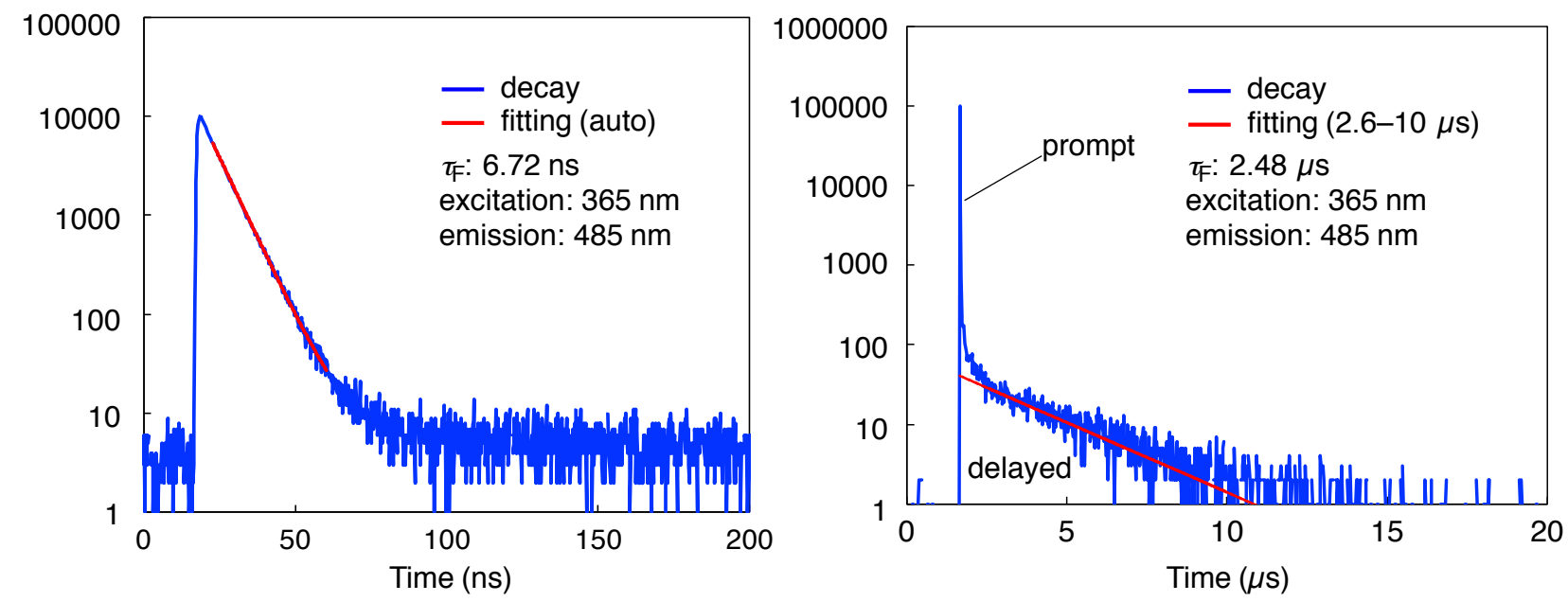

Figure S6. Transient decay spectra of V-DABNA-Mes in toluene $(0.02 \mathrm{mM})$. A red curve is single exponential fitting data.

(13) Masui, K.; Nakanotani, H.; Adachi, C. Org. Electron. 2013, 14, 2721.

(14) Zhang, Q.; Kuwabara, H.; Potscavage, W. J.; Huang, S.; Hatae, Y.; Shibata, T.; Adachi, C. J. Am. Chem. Soc. 2014, 136, 18070.

(15) Kaji, H.; Suzuki, H.; Fukushima, T.; Shizu, K.; Katsuaki, K.; Kubo, S.; Komino, T.; Oiwa, H.; Suzuki, F.; Wakamiya, A.; Murata, Y.; Adachi, C. Nat. Commun. 2015, 6, 8476. 
Measurement of ionization potential and optical band gap. Ionization potentials $\left(I_{\mathrm{p}}\right)$ of the thin films were measured by photoemission yield spectroscopy in air (PYSA) using an AC-2 (RIKEN KEIKI Co., Ltd.) system at room temperature (298 K). The UV-visible absorption spectra of the thin films were measured using a UV/VIS/NIR Spectrometer Cary 5e (Varian, Inc.). Furthermore, the optical band gaps $\left(E_{\mathrm{g}}\right)$ were estimated based on the absorption edge wavelength. The electron affinities $\left(E_{\mathrm{a}}\right)$ were calculated using the $I_{\mathrm{p}}$ and $E_{\mathrm{g}}$ values. Thin films were spin-coated on the cleaned glass substrates.

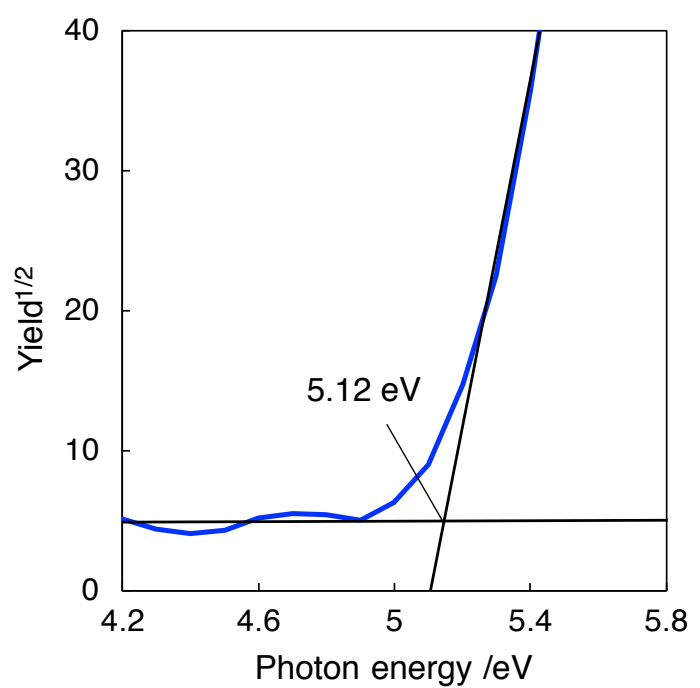

Figure S7. Photoelectron yield spectra of the spin-coated thin films of V-DABNA-Mes (neat) after light illumination from a D2 lamp in vacuo.

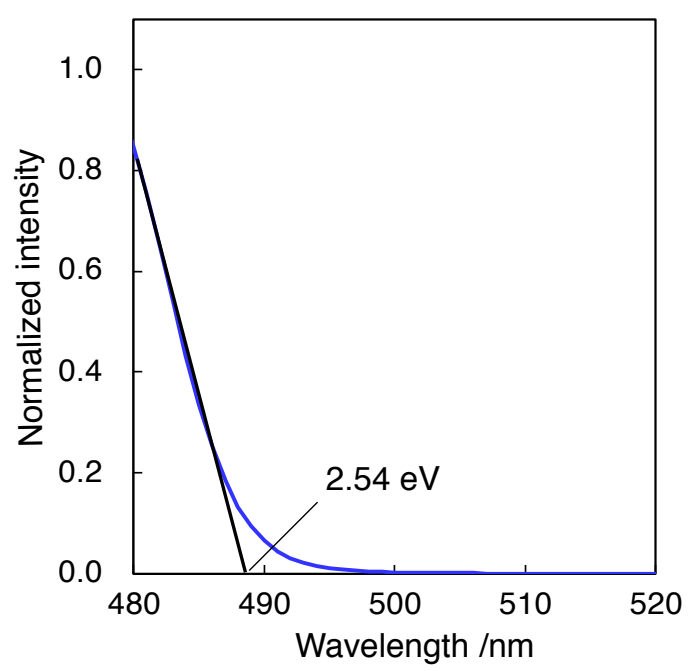

Figure S8. UV/Vis absorption spectra of V-DABNA-Mes (0.02 $\mathrm{mM}$ in toluene). 
Table S7. Optical band gap $\left(E_{\mathrm{g}}\right)$, Ionization potential $\left(I_{\mathrm{p}}\right)$, and electron affinity $\left(E_{\mathrm{a}}\right)$ of $\mathbf{A}, \mathbf{C}$ and V-DABNA-Mes.

\begin{tabular}{|c|c|c|c|}
\hline Compounds & $\begin{array}{c}E_{\mathrm{g}}{ }^{a} \\
{[\mathrm{eV}]}\end{array}$ & $\begin{array}{c}I_{\mathrm{p}}^{b} \\
{[\mathrm{eV}]}\end{array}$ & $\begin{array}{c}E_{\mathrm{a}}^{c} \\
{[\mathrm{eV}]}\end{array}$ \\
\hline $\mathbf{A}$ (before annealing) ${ }^{d}$ & 3.26 & -5.61 & -2.35 \\
\hline $\mathbf{A}$ (after annealing) ${ }^{d}$ & 3.27 & -5.68 & -2.41 \\
\hline C & 3.63 & $<-6.00$ & - \\
\hline V-DABNA-Mes & $2.54^{e}$ & -5.12 & -2.58 \\
\hline
\end{tabular}

aOptical band gap. ${ }^{b}$ Determined by photoelectron yield spectroscopy in thin films. ${ }^{c}$ Calculated from $I_{\mathrm{p}}$ and $E_{\mathrm{g}}$. ${ }^{d}$ ref [10]. ein toluene (0.02 mM).

Device fabrication and measurement of EL characteristics. OLEDs were fabricated on glass substrates coated with a patterned transparent ITO conductive layer $(45 \mathrm{~nm})$. The substrates were cleaned in a detergent solution for $15 \mathrm{~min}$ and in distilled water for $10 \mathrm{~min}$ using an ultrasonic bath, and then dried by hot air. Plexcore ${ }^{\circledR}$ OC AQ-1200 was spin-coated to form a hole injection layer $(35 \mathrm{~nm})$ and heated at $170{ }^{\circ} \mathrm{C}$ for $15 \mathrm{~min}$ on a hot plate in the ambient atmosphere. Polymer $\mathbf{A}(0.6$ $\mathrm{wt} \%$ in xylene) was spin-coated to form a hole transporting layer $(20 \mathrm{~nm})$ and heated at $200{ }^{\circ} \mathrm{C}$ for $30 \mathrm{~min}$ on a hot plate under a nitrogen atmosphere. A 99:1 mixture of polymer $\mathbf{C}$ and V-DABNA-Mes (1.4 $\mathrm{wt} \%$ in xylene) were spin-coated to form a layer $(70 \mathrm{~nm})$ and heated at 150 ${ }^{\circ} \mathrm{C}$ for $10 \mathrm{~min}$ on a hot plate under a nitrogen atmosphere. Successively, $3 \mathrm{~nm}$ of NaF and $80 \mathrm{~nm}$ of Al were vacuum deposited on the substrates in an inert chamber under a pressure of $4 \times 10^{-4} \mathrm{~Pa}$. The fabricated device structures were following: ITO (45 nm); AQ-1200 (35 nm); A (20 nm); $1 \mathrm{wt} \%$ of V-DABNA-Mes and $99 \mathrm{wt} \%$ of $\mathbf{C}(70 \mathrm{~nm})$; NaF $(4 \mathrm{~nm})$; Al $(120 \mathrm{~nm})$. The OLED characteristics of all fabricated devices were evaluated at room temperature $(298 \mathrm{~K})$ in an air atmosphere using OLED 25ch-IVL instrument (System Engineers' Co., Ltd.). The EQE was calculated using the EL spectrum, assuming the light-emitting surface to be a perfect diffusion surface, and adding up all radiance elements from every angle and inputting them into the formula for obtaining EQE. 


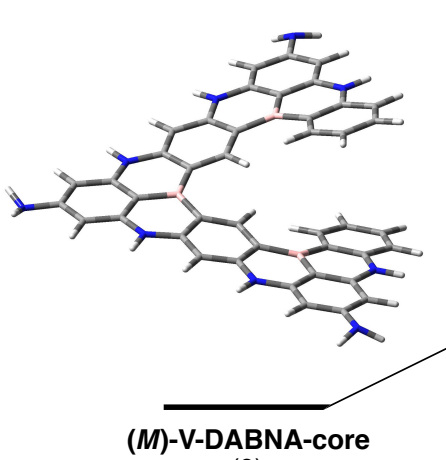

(0)

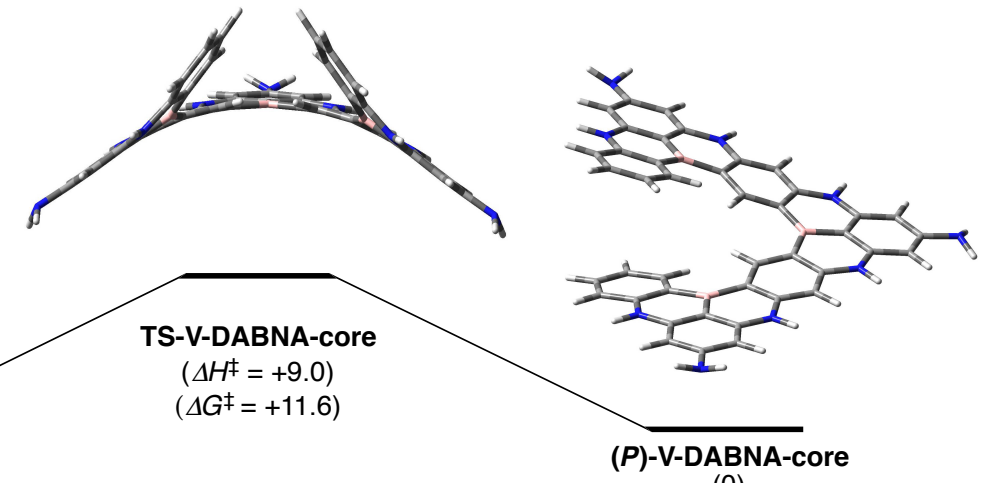

(0)

Figure S9. Energy diagram for isomerization pathway of V-DABNA-core at the B3LYP/6-31G(d) level of theory (Gaussian 09). Relative energies $(\Delta H, \Delta G)$ relative to $(\boldsymbol{M} / \boldsymbol{P})-\mathbf{V}-\mathbf{D A B N A}$-core are given in $\mathrm{kcal} / \mathrm{mol}$.

Table S8. Number of Imaginary Frequencies $\left(N_{\text {imag }}\right)$, Electronic Energies (E: RB3LYP), Zero-point Energy Corrected Energies (E + ZPE: Sum of Electronic and Zero-point Energies), Enthalpies (H: Sum of Electronic and Thermal Enthalpies), and Gibbs Free Energies (G: Sum of Electronic and Thermal Free Energies) of Stationary Points (in hartrees) at the B3LYP/6-31G(d) level of theory (Gaussian 09). Relative Energies are Given in kcal/mol.

\begin{tabular}{|c|c|c|c|c|c|}
\hline & $N_{\text {imag }}$ & $\begin{array}{c}E \\
\text { (hartrees) }\end{array}$ & $\begin{array}{c}\Delta E \\
(\mathrm{kcal} / \mathrm{mol})\end{array}$ & $\begin{array}{c}E+Z P E \\
\text { (hartrees) }\end{array}$ & $\begin{array}{l}\Delta(E+Z P E) \\
(\mathrm{kcal} / \mathrm{mol})\end{array}$ \\
\hline (M)-V-DABNA-core (chiral) & 0 & -2186.116598 & 0 & -2185.458856 & 0 \\
\hline \multirow[t]{2}{*}{ TS-V-DABNA-core } & 1 & -2186.100729 & 10.0 & -2185.443575 & 9.6 \\
\hline & $N_{\text {imag }}$ & $\begin{array}{c}H \\
\text { (hartrees) }\end{array}$ & $\begin{array}{c}\Delta H \\
(\mathrm{kcal} / \mathrm{mol})\end{array}$ & $\begin{array}{c}G \\
\text { (hartrees) }\end{array}$ & $\begin{array}{c}\Delta G \\
(\mathrm{kcal} / \mathrm{mol})\end{array}$ \\
\hline$(M)$-V-DABNA-core (chiral) & 0 & -2185.417689 & 0 & -2185.529604 & 0 \\
\hline TS-V-DABNA-core & 1 & -2185.403403 & 9.0 & -2185.511096 & 11.6 \\
\hline
\end{tabular}


Cartesian Coordinate

V-DABNA-Mes $\left(\mathrm{S}_{0}, C_{1}\right.$ symmetry)

$\mathrm{E}(\mathrm{B} 3 \mathrm{LYP} / 6-31 \mathrm{G}(\mathrm{d}))=-5430.451525$ hartree

\begin{tabular}{|c|c|c|c|c|c|}
\hline \multirow{2}{*}{$\begin{array}{l}\text { Center } \\
\text { Number }\end{array}$} & \multirow{2}{*}{$\begin{array}{l}\text { Atomic } \\
\text { Number }\end{array}$} & \multirow{2}{*}{$\begin{array}{l}\text { Atomic } \\
\text { Type }\end{array}$} & \multicolumn{3}{|c|}{ Coordinates (Angstroms) } \\
\hline & & & $X$ & $\mathrm{Y}$ & Z \\
\hline 1 & 7 & 0 & -4.589923 & -4.231777 & -1.982616 \\
\hline 2 & 7 & 0 & 2.607857 & 3.369042 & -0.747249 \\
\hline 3 & 7 & 0 & 0.579896 & 7.741269 & -0.071084 \\
\hline 4 & 7 & 0 & 5.252547 & -0.651588 & -0.410543 \\
\hline 5 & 7 & 0 & 8.446152 & -4.084717 & 0.876911 \\
\hline 6 & 7 & 0 & 3.678766 & -4.961591 & 1.240735 \\
\hline 7 & 6 & 0 & -0.889822 & 4.330598 & 0.091070 \\
\hline 8 & 7 & 0 & -8.751768 & -3.354848 & 0.376492 \\
\hline 9 & 6 & 0 & 3.971743 & -0.067844 & -0.416846 \\
\hline 10 & 6 & 0 & -1.346714 & 1.481878 & -0.309817 \\
\hline 11 & 6 & 0 & 0.462883 & 6.323623 & -0.118118 \\
\hline 12 & 6 & 0 & -4.924458 & -2.062525 & -0.921652 \\
\hline 13 & 6 & 0 & 1.478069 & 4.155114 & -0.459596 \\
\hline 14 & 6 & 0 & 4.426638 & -2.800882 & 0.395677 \\
\hline 15 & 6 & 0 & -5.402254 & -3.363660 & -1.237246 \\
\hline 16 & 6 & 0 & 5.515545 & -1.945613 & 0.069661 \\
\hline 17 & 6 & 0 & -2.816846 & -2.555726 & -2.338740 \\
\hline 18 & 6 & 0 & 2.809039 & -0.847476 & -0.133029 \\
\hline 19 & 6 & 0 & 1.436996 & 1.234197 & -0.359841 \\
\hline 20 & 6 & 0 & 4.727612 & -4.096773 & 0.899742 \\
\hline 21 & 6 & 0 & 2.326085 & -4.703848 & 0.939005 \\
\hline 22 & 6 & 0 & 2.635981 & 1.968118 & -0.604029 \\
\hline 23 & 6 & 0 & -5.775388 & -1.198888 & -0.178015 \\
\hline 24 & 6 & 0 & -7.470200 & -2.920981 & -0.063534 \\
\hline 25 & 6 & 0 & -3.373982 & -3.844274 & -2.581622 \\
\hline 26 & 6 & 0 & 7.098570 & -3.655639 & 0.717409 \\
\hline 27 & 6 & 0 & 1.926129 & -3.460921 & 0.369242 \\
\hline 28 & 6 & 0 & 1.715402 & 8.340001 & 0.537926 \\
\hline 29 & 6 & 0 & 2.336756 & 9.455351 & -0.047325 \\
\hline 30 & 6 & 0 & 2.232879 & 7.827400 & 1.739125 \\
\hline 31 & 6 & 0 & 3.441257 & 10.046861 & 0.562911 \\
\hline 32 & 1 & 0 & 1.949054 & 9.852926 & -0.979826 \\
\hline 33 & 6 & 0 & 3.348381 & 8.414992 & 2.332256 \\
\hline 34 & 1 & 0 & 1.753886 & 6.970098 & 2.201111 \\
\hline 35 & 6 & 0 & 3.957609 & 9.530386 & 1.753063 \\
\hline 36 & 1 & 0 & 3.908625 & 10.909439 & 0.094687 \\
\hline 37 & 1 & 0 & 3.732885 & 8.005902 & 3.263230 \\
\hline 38 & 1 & 0 & 4.822147 & 9.990903 & 2.222923 \\
\hline 39 & 6 & 0 & -0.440310 & 8.558928 & -0.627083 \\
\hline 40 & 6 & 0 & -0.865931 & 9.721436 & 0.036285 \\
\hline 41 & 6 & 0 & -1.036449 & 8.219844 & -1.852977 \\
\hline
\end{tabular}




\begin{tabular}{|c|c|c|c|c|c|}
\hline 42 & 6 & 0 & -1.855945 & 10.527911 & -0.521869 \\
\hline 43 & 1 & 0 & -0.415999 & 9.986667 & 0.987664 \\
\hline 44 & 6 & 0 & -2.037982 & 9.023249 & -2.394153 \\
\hline 45 & 1 & 0 & -0.707473 & 7.326706 & -2.374309 \\
\hline 46 & 6 & 0 & -2.451809 & 10.184176 & -1.736993 \\
\hline 47 & 1 & 0 & -2.172092 & 11.423938 & 0.006245 \\
\hline 48 & 1 & 0 & -2.486026 & 8.746012 & -3.345059 \\
\hline 49 & 1 & 0 & -3.227325 & 10.812295 & -2.166297 \\
\hline 50 & 6 & 0 & 6.370146 & 0.136360 & -0.866215 \\
\hline 51 & 6 & 0 & 7.134381 & 0.876252 & 0.040758 \\
\hline 52 & 6 & 0 & 6.693096 & 0.146192 & -2.225382 \\
\hline 53 & 6 & 0 & 8.222563 & 1.621838 & -0.414118 \\
\hline 54 & 6 & 0 & 7.779993 & 0.895851 & -2.676988 \\
\hline 55 & 6 & 0 & 8.546317 & 1.633257 & -1.772381 \\
\hline 56 & 1 & 0 & 8.818106 & 2.191753 & 0.293588 \\
\hline 57 & 1 & 0 & 8.029030 & 0.900666 & -3.734637 \\
\hline 58 & 6 & 0 & 3.825860 & 4.046982 & -1.112908 \\
\hline 59 & 6 & 0 & 4.136696 & 4.223832 & -2.463298 \\
\hline 60 & 6 & 0 & 4.690047 & 4.530452 & -0.126049 \\
\hline 61 & 6 & 0 & 5.313225 & 4.881241 & -2.825901 \\
\hline 62 & 6 & 0 & 5.863419 & 5.190507 & -0.492475 \\
\hline 63 & 6 & 0 & 6.177239 & 5.365292 & -1.841911 \\
\hline 64 & 1 & 0 & 5.552633 & 5.016414 & -3.877108 \\
\hline 65 & 1 & 0 & 6.530662 & 5.569374 & 0.276701 \\
\hline 66 & 6 & 0 & -3.211457 & 4.558502 & 0.804461 \\
\hline 67 & 6 & 0 & -3.401773 & 4.754785 & 2.174454 \\
\hline 68 & 6 & 0 & -4.060789 & 5.177669 & -0.117098 \\
\hline 69 & 6 & 0 & -4.442318 & 5.570045 & 2.622129 \\
\hline 70 & 6 & 0 & -5.099396 & 5.992668 & 0.334320 \\
\hline 71 & 6 & 0 & -5.291685 & 6.189508 & 1.703405 \\
\hline 72 & 1 & 0 & -4.587797 & 5.721295 & 3.688237 \\
\hline 73 & 1 & 0 & -5.755764 & 6.475935 & -0.384053 \\
\hline 74 & 6 & 0 & -6.273968 & 0.988680 & 0.772474 \\
\hline 75 & 6 & 0 & -7.143790 & 1.773113 & 0.010782 \\
\hline 76 & 6 & 0 & -6.311988 & 1.051779 & 2.168038 \\
\hline 77 & 6 & 0 & -8.051264 & 2.621265 & 0.646981 \\
\hline 78 & 6 & 0 & -7.220906 & 1.900712 & 2.800253 \\
\hline 79 & 6 & 0 & -8.091062 & 2.686000 & 2.041147 \\
\hline 80 & 1 & 0 & -8.727523 & 3.229885 & 0.052919 \\
\hline 81 & 1 & 0 & -7.250748 & 1.945871 & 3.885342 \\
\hline 82 & 6 & 0 & 9.417544 & -3.193060 & 1.405454 \\
\hline 83 & 6 & 0 & 9.099929 & -2.352718 & 2.485470 \\
\hline 84 & 6 & 0 & 10.711044 & -3.138457 & 0.860915 \\
\hline 85 & 6 & 0 & 10.053022 & -1.475413 & 2.998613 \\
\hline 86 & 1 & 0 & 8.104885 & -2.395114 & 2.916442 \\
\hline 87 & 6 & 0 & 11.662605 & -2.269945 & 1.392380 \\
\hline 88 & 1 & 0 & 10.963006 & -3.779264 & 0.022014 \\
\hline 89 & 6 & 0 & 11.341106 & -1.429841 & 2.460449 \\
\hline
\end{tabular}




\begin{tabular}{|c|c|c|c|c|c|}
\hline 90 & 1 & 0 & 9.789383 & -0.834712 & 3.836435 \\
\hline 91 & 1 & 0 & 12.658310 & -2.241706 & 0.957067 \\
\hline 92 & 1 & 0 & 12.084016 & -0.750173 & 2.868407 \\
\hline 93 & 6 & 0 & 8.818584 & -5.407301 & 0.515405 \\
\hline 94 & 6 & 0 & 8.325584 & -5.987761 & -0.664962 \\
\hline 95 & 6 & 0 & 9.687885 & -6.153919 & 1.327349 \\
\hline 96 & 6 & 0 & 8.690983 & -7.285417 & -1.016667 \\
\hline 97 & 1 & 0 & 7.658554 & -5.414325 & -1.300544 \\
\hline 98 & 6 & 0 & 10.061212 & -7.444881 & 0.958104 \\
\hline 99 & 1 & 0 & 10.066750 & -5.716349 & 2.245488 \\
\hline 100 & 6 & 0 & 9.563932 & -8.021577 & -0.212358 \\
\hline 101 & 1 & 0 & 8.301296 & -7.716997 & -1.935220 \\
\hline 102 & 1 & 0 & 10.734980 & -8.007348 & 1.599504 \\
\hline 103 & 1 & 0 & 9.852677 & -9.030332 & -0.493968 \\
\hline 104 & 6 & 0 & 4.014288 & -6.219419 & 1.858624 \\
\hline 105 & 6 & 0 & 4.054151 & -6.317650 & 3.251656 \\
\hline 106 & 6 & 0 & 4.300946 & -7.336548 & 1.068893 \\
\hline 107 & 6 & 0 & 4.378998 & -7.534203 & 3.853980 \\
\hline 108 & 1 & 0 & 3.828854 & -5.440439 & 3.850794 \\
\hline 109 & 6 & 0 & 4.627208 & -8.550591 & 1.674402 \\
\hline 110 & 1 & 0 & 4.267736 & -7.243598 & -0.012418 \\
\hline 111 & 6 & 0 & 4.666101 & -8.651264 & 3.066864 \\
\hline 112 & 1 & 0 & 4.408642 & -7.607857 & 4.937658 \\
\hline 113 & 1 & 0 & 4.852758 & -9.416459 & 1.058122 \\
\hline 114 & 1 & 0 & 4.920867 & -9.597192 & 3.536922 \\
\hline 115 & 6 & 0 & -9.583322 & -4.109783 & -0.494230 \\
\hline 116 & 6 & 0 & -10.298566 & -5.220359 & -0.017685 \\
\hline 117 & 6 & 0 & -9.704855 & -3.753206 & -1.847354 \\
\hline 118 & 6 & 0 & -11.121230 & -5.948409 & -0.875348 \\
\hline 119 & 1 & 0 & -10.204836 & -5.506672 & 1.025011 \\
\hline 120 & 6 & 0 & -10.516101 & -4.497786 & -2.701000 \\
\hline 121 & 1 & 0 & -9.160205 & -2.891618 & -2.220050 \\
\hline 122 & 6 & 0 & -11.232997 & -5.596657 & -2.222051 \\
\hline 123 & 1 & 0 & -11.666892 & -6.805306 & -0.488500 \\
\hline 124 & 1 & 0 & -10.599191 & -4.205797 & -3.744875 \\
\hline 125 & 1 & 0 & -11.870508 & -6.170260 & -2.888988 \\
\hline 126 & 6 & 0 & -9.195653 & -3.045456 & 1.690201 \\
\hline 127 & 6 & 0 & -10.525794 & -2.659301 & 1.923390 \\
\hline 128 & 6 & 0 & -8.311176 & -3.125156 & 2.778585 \\
\hline 129 & 6 & 0 & -10.958555 & -2.370739 & 3.216244 \\
\hline 130 & 1 & 0 & -11.214135 & -2.587790 & 1.087314 \\
\hline 131 & 6 & 0 & -8.748932 & -2.817212 & 4.064988 \\
\hline 132 & 1 & 0 & -7.283693 & -3.429332 & 2.607291 \\
\hline 133 & 6 & 0 & -10.074706 & -2.442925 & 4.294904 \\
\hline 134 & 1 & 0 & -11.991800 & -2.073544 & 3.376891 \\
\hline 135 & 1 & 0 & -8.050072 & -2.886028 & 4.894821 \\
\hline 136 & 1 & 0 & -10.414300 & -2.211128 & 5.300480 \\
\hline 137 & 6 & 0 & -5.068425 & -5.571802 & -2.212982 \\
\hline
\end{tabular}




\begin{tabular}{|c|c|c|c|c|c|}
\hline 138 & 6 & 0 & -4.709488 & -6.596944 & -1.334407 \\
\hline 139 & 6 & 0 & -5.889560 & -5.845434 & -3.310572 \\
\hline 140 & 6 & 0 & -5.170710 & -7.895662 & -1.555381 \\
\hline 141 & 1 & 0 & -4.072243 & -6.368650 & -0.485265 \\
\hline 142 & 6 & 0 & -6.349839 & -7.144691 & -3.527693 \\
\hline 143 & 1 & 0 & -6.161350 & -5.038039 & -3.983839 \\
\hline 144 & 6 & 0 & -5.990880 & -8.171139 & -2.651355 \\
\hline 145 & 1 & 0 & -4.889756 & -8.690826 & -0.870286 \\
\hline 146 & 1 & 0 & -6.989745 & -7.353826 & -4.380406 \\
\hline 147 & 1 & 0 & -6.350600 & -9.182203 & -2.821333 \\
\hline 148 & 6 & 0 & 0.233493 & 3.516957 & -0.214491 \\
\hline 149 & 6 & 0 & -2.395332 & 2.363162 & 0.092199 \\
\hline 150 & 6 & 0 & -4.036738 & 0.569512 & -0.125261 \\
\hline 151 & 6 & 0 & -3.068200 & -0.272024 & -0.751730 \\
\hline 152 & 7 & 0 & -2.131282 & 3.720554 & 0.348490 \\
\hline 153 & 7 & 0 & -5.342848 & 0.106181 & 0.115556 \\
\hline 154 & 5 & 0 & 0.102965 & 2.007252 & -0.299891 \\
\hline 155 & 5 & 0 & 2.990728 & -2.349867 & 0.194555 \\
\hline 156 & 5 & 0 & -3.540789 & -1.613999 & -1.346845 \\
\hline 157 & 6 & 0 & 3.870182 & 1.308751 & -0.663459 \\
\hline 158 & 1 & 0 & 4.766698 & 1.879788 & -0.844840 \\
\hline 159 & 6 & 0 & 1.594013 & -0.139851 & -0.113158 \\
\hline 160 & 1 & 0 & 0.702835 & -0.687205 & 0.166699 \\
\hline 161 & 6 & 0 & 1.366747 & -5.709629 & 1.192017 \\
\hline 162 & 1 & 0 & 1.660834 & -6.642969 & 1.654820 \\
\hline 163 & 6 & 0 & 0.041770 & -5.524934 & 0.827191 \\
\hline 164 & 1 & 0 & -0.674747 & -6.319380 & 1.022790 \\
\hline 165 & 6 & 0 & -0.363973 & -4.347537 & 0.190714 \\
\hline 166 & 1 & 0 & -1.389292 & -4.215384 & -0.140326 \\
\hline 167 & 6 & 0 & 0.573074 & -3.347936 & -0.020885 \\
\hline 168 & 1 & 0 & 0.256343 & -2.450366 & -0.536850 \\
\hline 169 & 6 & 0 & 6.056371 & -4.509187 & 1.085739 \\
\hline 170 & 1 & 0 & 6.293839 & -5.478879 & 1.498848 \\
\hline 171 & 6 & 0 & 6.840727 & -2.382938 & 0.196799 \\
\hline 172 & 1 & 0 & 7.673351 & -1.755980 & -0.087055 \\
\hline 173 & 6 & 0 & 1.583489 & 5.553304 & -0.445149 \\
\hline 174 & 1 & 0 & 2.514580 & 6.052635 & -0.671370 \\
\hline 175 & 6 & 0 & -0.769040 & 5.724998 & 0.166884 \\
\hline 176 & 1 & 0 & -1.609051 & 6.351961 & 0.429594 \\
\hline 177 & 6 & 0 & -1.750320 & 0.214062 & -0.752730 \\
\hline 178 & 1 & 0 & -0.976357 & -0.439941 & -1.135182 \\
\hline 179 & 6 & 0 & -3.703457 & 1.881759 & 0.242665 \\
\hline 180 & 1 & 0 & -4.467353 & 2.535172 & 0.633673 \\
\hline 181 & 6 & 0 & -7.046055 & -1.620729 & 0.234428 \\
\hline 182 & 1 & 0 & -7.709548 & -0.966143 & 0.780946 \\
\hline 183 & 6 & 0 & -6.658853 & -3.798000 & -0.788467 \\
\hline 184 & 1 & 0 & -7.016542 & -4.797039 & -0.991926 \\
\hline 185 & 6 & 0 & -2.714514 & -4.748250 & -3.444588 \\
\hline
\end{tabular}




\begin{tabular}{|c|c|c|c|c|c|}
\hline 186 & 1 & 0 & -3.118040 & -5.738533 & -3.612491 \\
\hline 187 & 6 & 0 & -1.553634 & -4.372059 & -4.103168 \\
\hline 188 & 1 & 0 & -1.068632 & -5.083984 & -4.766473 \\
\hline 189 & 6 & 0 & -1.023467 & -3.088104 & -3.936934 \\
\hline 190 & 1 & 0 & -0.131228 & -2.783845 & -4.476654 \\
\hline 191 & 6 & 0 & -1.655539 & -2.211853 & -3.067573 \\
\hline 192 & 1 & 0 & -1.256474 & -1.209582 & -2.958029 \\
\hline 193 & 6 & 0 & 4.325528 & 4.330603 & 1.356781 \\
\hline 194 & 1 & 0 & 5.023387 & 4.861201 & 1.970262 \\
\hline 195 & 1 & 0 & 3.338565 & 4.703560 & 1.534843 \\
\hline 196 & 1 & 0 & 4.361364 & 3.288191 & 1.595517 \\
\hline 197 & 6 & 0 & 3.169314 & 3.683793 & -3.532939 \\
\hline 198 & 1 & 0 & 3.013456 & 2.636774 & -3.376869 \\
\hline 199 & 1 & 0 & 2.233975 & 4.198348 & -3.460312 \\
\hline 200 & 1 & 0 & 3.588369 & 3.841038 & -4.504827 \\
\hline 201 & 6 & 0 & 7.472861 & 6.094238 & -2.243909 \\
\hline 202 & 1 & 0 & 8.145145 & 6.111797 & -1.411667 \\
\hline 203 & 1 & 0 & 7.931948 & 5.580346 & -3.062477 \\
\hline 204 & 1 & 0 & 7.241695 & 7.097046 & -2.536891 \\
\hline 205 & 6 & 0 & 6.764950 & 0.848006 & 1.535523 \\
\hline 206 & 1 & 0 & 6.988471 & -0.117055 & 1.939990 \\
\hline 207 & 1 & 0 & 7.329641 & 1.592643 & 2.056617 \\
\hline 208 & 1 & 0 & 5.720053 & 1.048807 & 1.648531 \\
\hline 209 & 6 & 0 & 5.837064 & -0.677933 & -3.204987 \\
\hline 210 & 1 & 0 & 5.978956 & -1.720834 & -3.012307 \\
\hline 211 & 1 & 0 & 4.804914 & -0.428198 & -3.073838 \\
\hline 212 & 1 & 0 & 6.132544 & -0.457375 & -4.209449 \\
\hline 213 & 6 & 0 & 9.748868 & 2.455920 & -2.271076 \\
\hline 214 & 1 & 0 & 9.486359 & 2.956612 & -3.179534 \\
\hline 215 & 1 & 0 & 10.018029 & 3.179340 & -1.530053 \\
\hline 216 & 1 & 0 & 10.577753 & 1.803396 & -2.450138 \\
\hline 217 & 6 & 0 & -5.344809 & 0.176033 & 2.986106 \\
\hline 218 & 1 & 0 & -5.204876 & -0.761054 & 2.488928 \\
\hline 219 & 1 & 0 & -4.402825 & 0.675130 & 3.078128 \\
\hline 220 & 1 & 0 & -5.754726 & 0.005552 & 3.959658 \\
\hline 221 & 6 & 0 & -9.095298 & 3.620552 & 2.740948 \\
\hline 222 & 1 & 0 & -8.706223 & 3.912793 & 3.693899 \\
\hline 223 & 1 & 0 & -9.252895 & 4.490379 & 2.138067 \\
\hline 224 & 1 & 0 & -10.024526 & 3.107817 & 2.877103 \\
\hline 225 & 6 & 0 & -7.084664 & 1.685133 & -1.525565 \\
\hline 226 & 1 & 0 & -7.601859 & 0.807421 & -1.852721 \\
\hline 227 & 1 & 0 & -7.547657 & 2.551145 & -1.950490 \\
\hline 228 & 1 & 0 & -6.063394 & 1.635705 & -1.840946 \\
\hline 229 & 6 & 0 & -2.452542 & 4.063417 & 3.170732 \\
\hline 230 & 1 & 0 & -2.223650 & 3.078593 & 2.820547 \\
\hline 231 & 1 & 0 & -1.549314 & 4.630816 & 3.255221 \\
\hline 232 & 1 & 0 & -2.925130 & 4.000477 & 4.128645 \\
\hline 233 & 6 & 0 & -6.437642 & 7.091156 & 2.198799 \\
\hline
\end{tabular}




$\begin{array}{lllllr}234 & 1 & 0 & -7.231034 & 7.086414 & 1.480882 \\ 235 & 1 & 0 & -6.801749 & 6.723083 & 3.135201 \\ 236 & 1 & 0 & -6.076358 & 8.090441 & 2.324517 \\ 237 & 6 & 0 & -3.830475 & 4.950240 & -1.622698 \\ 238 & 1 & 0 & -4.503882 & 5.564370 & -2.183294 \\ 239 & 1 & 0 & -2.822090 & 5.206932 & -1.872034 \\ 240 & 1 & 0 & -4.005430 & 3.921398 & -1.858865\end{array}$

1 ( $\mathrm{S}_{0}, C_{1}$ symmetry)

$\mathrm{E}(\mathrm{B} 3 \mathrm{LYP} / 6-31 \mathrm{G}(\mathrm{d}))=-5361.085813$ hartree

\begin{tabular}{cccccc} 
Center & Atomic & Atomic & \multicolumn{2}{c}{ Coordinates (Angstroms) } \\
Number & Number & Type & $\mathrm{X}$ & $\mathrm{Y}$ & $\mathrm{Z}$ \\
-1 & 6 & 0 & 9.495496 & -1.273418 & -0.183618 \\
2 & 6 & 0 & 10.017217 & 1.380104 & -0.795412 \\
3 & 1 & 0 & 9.316476 & -2.313784 & 0.056715 \\
4 & 6 & 0 & 8.673838 & 0.976988 & -0.689493 \\
5 & 6 & 0 & 8.422034 & -0.383428 & -0.370924 \\
6 & 6 & 0 & 6.093798 & 1.343557 & -0.887841 \\
7 & 6 & 0 & 4.948081 & 2.149292 & -0.787295 \\
8 & 6 & 0 & 5.985103 & 0.033104 & -0.321278 \\
9 & 1 & 0 & 5.018328 & 3.163604 & -1.158430 \\
10 & 6 & 0 & 4.752063 & -0.424598 & 0.173781 \\
11 & 1 & 0 & 4.677705 & -1.433110 & 0.551963 \\
12 & 6 & 0 & 3.717163 & 1.758771 & -0.245822 \\
13 & 6 & 0 & 3.618334 & 0.401411 & 0.186380 \\
14 & 6 & 0 & 1.186631 & 1.985082 & 0.835058 \\
15 & 6 & 0 & -0.040178 & 2.677178 & 0.705557 \\
16 & 6 & 0 & 1.182132 & 0.583291 & 0.603792 \\
17 & 6 & 0 & -0.013827 & -0.105807 & 0.349881 \\
18 & 1 & 0 & -0.003810 & -1.176156 & 0.213012 \\
19 & 6 & 0 & -1.223035 & 0.602703 & 0.274672 \\
20 & 6 & 0 & -1.254225 & 2.017233 & 0.403499 \\
21 & 6 & 0 & -3.676789 & 0.351132 & 0.514144 \\
22 & 6 & 0 & -4.798334 & -0.471959 & 0.335214 \\
23 & 6 & 0 & -3.817908 & 1.626746 & 1.140068 \\
24 & 1 & 0 & -4.689106 & -1.411161 & -0.185862 \\
25 & 6 & 0 & -5.083117 & 1.925729 & 1.660540 \\
26 & 1 & 0 & -5.187824 & 2.872015 & 2.175382 \\
27 & 6 & 0 & -6.063536 & -0.100378 & 0.821169 \\
28 & 6 & 0 & -6.222069 & 1.109081 & 1.571042 \\
29 & 6 & 0 & -8.447496 & -0.472103 & 0.280570 \\
30 & 6 & 0 & -9.475764 & -1.362238 & -0.079740 \\
31 & 6 & 0 & -8.711285 & 0.919992 & 0.371014 \\
32 & 1 & 0 & -9.287641 & -2.426217 & -0.148973 \\
33 & 6 & 0 & -10.017528 & 1.352364 & 0.079047
\end{tabular}




\begin{tabular}{|c|c|c|c|c|c|}
\hline 34 & 6 & 0 & -10.761886 & -0.886137 & -0.367191 \\
\hline 35 & 7 & 0 & -7.156074 & -0.944953 & 0.559002 \\
\hline 36 & 7 & 0 & -2.422460 & -0.093555 & 0.055033 \\
\hline 37 & 7 & 0 & 2.394930 & -0.123559 & 0.644045 \\
\hline 38 & 7 & 0 & 7.095605 & -0.825858 & -0.251708 \\
\hline 39 & 6 & 0 & -6.947199 & -2.376820 & 0.538477 \\
\hline 40 & 6 & 0 & -6.585123 & -3.005234 & -0.666831 \\
\hline 41 & 6 & 0 & -7.136236 & -3.110146 & 1.719975 \\
\hline 42 & 6 & 0 & -6.416263 & -4.391841 & -0.662872 \\
\hline 43 & 6 & 0 & -6.954233 & -4.497414 & 1.674043 \\
\hline 44 & 6 & 0 & -6.597017 & -5.156623 & 0.495683 \\
\hline 45 & 1 & 0 & -6.138494 & -4.887616 & -1.591013 \\
\hline 46 & 1 & 0 & -7.100390 & -5.074781 & 2.584474 \\
\hline 47 & 6 & 0 & -2.356330 & -1.357844 & -0.645609 \\
\hline 48 & 6 & 0 & -2.160767 & -2.544416 & 0.083341 \\
\hline 49 & 6 & 0 & -2.489947 & -1.367871 & -2.042972 \\
\hline 50 & 6 & 0 & -2.100372 & -3.749042 & -0.621815 \\
\hline 51 & 6 & 0 & -2.422056 & -2.599165 & -2.704295 \\
\hline 52 & 6 & 0 & -2.225901 & -3.797844 & -2.014440 \\
\hline 53 & 1 & 0 & -1.951412 & -4.673419 & -0.067226 \\
\hline 54 & 1 & 0 & -2.525139 & -2.618169 & -3.787274 \\
\hline 55 & 6 & 0 & 2.374771 & -1.481291 & 1.143932 \\
\hline 56 & 6 & 0 & 2.589062 & -1.704394 & 2.513989 \\
\hline 57 & 6 & 0 & 2.134511 & -2.542970 & 0.254813 \\
\hline 58 & 6 & 0 & 2.559302 & -3.022310 & 2.981181 \\
\hline 59 & 6 & 0 & 2.113496 & -3.842485 & 0.769569 \\
\hline 60 & 6 & 0 & 2.326930 & -4.103638 & 2.126671 \\
\hline 61 & 1 & 0 & 2.719802 & -3.205787 & 4.041675 \\
\hline 62 & 1 & 0 & 1.923492 & -4.671273 & 0.090579 \\
\hline 63 & 6 & 0 & 6.879607 & -2.236866 & -0.013920 \\
\hline 64 & 6 & 0 & 6.832830 & -2.716396 & 1.306440 \\
\hline 65 & 6 & 0 & 6.745257 & -3.100311 & -1.113527 \\
\hline 66 & 6 & 0 & 6.651396 & -4.088462 & 1.504279 \\
\hline 67 & 6 & 0 & 6.564830 & -4.464940 & -0.864931 \\
\hline 68 & 6 & 0 & 6.522123 & -4.979762 & 0.433993 \\
\hline 69 & 1 & 0 & 6.613097 & -4.469341 & 2.522870 \\
\hline 70 & 1 & 0 & 6.459010 & -5.141296 & -1.710619 \\
\hline 71 & 6 & 0 & 10.819007 & -0.826460 & -0.293447 \\
\hline 72 & 6 & 0 & 11.088786 & 0.512015 & -0.598181 \\
\hline 73 & 1 & 0 & 12.106629 & 0.876080 & -0.689340 \\
\hline 74 & 6 & 0 & -11.040485 & 0.482840 & -0.292673 \\
\hline 75 & 1 & 0 & -12.030358 & 0.870020 & -0.509708 \\
\hline 76 & 6 & 0 & -2.441197 & 4.532781 & 0.435819 \\
\hline 77 & 6 & 0 & -3.386942 & 5.326066 & -0.251203 \\
\hline 78 & 6 & 0 & -1.069943 & 4.855666 & 0.262343 \\
\hline 79 & 6 & 0 & -3.020106 & 6.387307 & -1.066053 \\
\hline 80 & 1 & 0 & -4.437483 & 5.066379 & -0.169943 \\
\hline 81 & 6 & 0 & -1.660336 & 6.665461 & -1.245679 \\
\hline
\end{tabular}




\begin{tabular}{|c|c|c|c|c|c|}
\hline 82 & 1 & 0 & -3.775300 & 6.972923 & -1.583004 \\
\hline 83 & 1 & 0 & -1.346811 & 7.462095 & -1.915531 \\
\hline 84 & 6 & 0 & 2.029163 & 3.936408 & 2.210392 \\
\hline 85 & 6 & 0 & 0.949925 & 4.693356 & 1.684053 \\
\hline 86 & 6 & 0 & 2.955076 & 4.612947 & 3.035470 \\
\hline 87 & 6 & 0 & 2.842489 & 5.963333 & 3.333028 \\
\hline 88 & 1 & 0 & 3.760382 & 4.042290 & 3.486561 \\
\hline 89 & 6 & 0 & 1.752041 & 6.680186 & 2.827411 \\
\hline 90 & 1 & 0 & 3.571365 & 6.449520 & 3.975572 \\
\hline 91 & 1 & 0 & 1.616942 & 7.727700 & 3.084484 \\
\hline 92 & 7 & 0 & -0.053299 & 4.070869 & 0.883383 \\
\hline 93 & 6 & 0 & -0.695572 & 5.904300 & -0.600737 \\
\hline 94 & 1 & 0 & 0.352927 & 6.105686 & -0.785305 \\
\hline 95 & 6 & 0 & 0.810465 & 6.053624 & 2.023109 \\
\hline 96 & 1 & 0 & -0.050433 & 6.612711 & 1.676365 \\
\hline 97 & 6 & 0 & -6.391132 & -2.206169 & -1.932904 \\
\hline 98 & 1 & 0 & -5.615808 & -1.441665 & -1.808205 \\
\hline 99 & 1 & 0 & -6.097482 & -2.857523 & -2.761381 \\
\hline 100 & 1 & 0 & -7.311109 & -1.683687 & -2.220531 \\
\hline 101 & 6 & 0 & -6.406863 & -6.655365 & 0.464346 \\
\hline 102 & 1 & 0 & -5.373582 & -6.920650 & 0.207406 \\
\hline 103 & 1 & 0 & -6.636308 & -7.108461 & 1.433900 \\
\hline 104 & 1 & 0 & -7.054562 & -7.125031 & -0.285985 \\
\hline 105 & 6 & 0 & -2.130137 & -5.114196 & -2.750342 \\
\hline 106 & 1 & 0 & -2.709533 & -5.897631 & -2.248365 \\
\hline 107 & 1 & 0 & -2.498274 & -5.026679 & -3.777757 \\
\hline 108 & 1 & 0 & -1.091296 & -5.465995 & -2.802265 \\
\hline 109 & 6 & 0 & 2.330956 & -5.521227 & 2.649930 \\
\hline 110 & 1 & 0 & 2.070759 & -5.557300 & 3.713198 \\
\hline 111 & 1 & 0 & 1.621351 & -6.152795 & 2.104030 \\
\hline 112 & 1 & 0 & 3.322185 & -5.981233 & 2.541368 \\
\hline 113 & 6 & 0 & 6.369687 & -6.463388 & 0.677209 \\
\hline 114 & 1 & 0 & 5.790519 & -6.663923 & 1.585378 \\
\hline 115 & 1 & 0 & 5.870360 & -6.958644 & -0.162269 \\
\hline 116 & 1 & 0 & 7.347320 & -6.947127 & 0.804853 \\
\hline 117 & 6 & 0 & 6.978827 & -1.779134 & 2.480876 \\
\hline 118 & 1 & 0 & 6.900753 & -2.325691 & 3.425346 \\
\hline 119 & 1 & 0 & 7.947563 & -1.265962 & 2.464002 \\
\hline 120 & 1 & 0 & 6.206048 & -1.002085 & 2.470997 \\
\hline 121 & 6 & 0 & 2.838703 & -0.554037 & 3.459390 \\
\hline 122 & 1 & 0 & 1.997123 & 0.148373 & 3.466326 \\
\hline 123 & 1 & 0 & 2.987089 & -0.916580 & 4.480928 \\
\hline 124 & 1 & 0 & 3.727629 & 0.017778 & 3.168719 \\
\hline 125 & 6 & 0 & -2.019588 & -2.519729 & 1.586191 \\
\hline 126 & 1 & 0 & -2.903663 & -2.082418 & 2.064221 \\
\hline 127 & 1 & 0 & -1.885458 & -3.531676 & 1.979858 \\
\hline 128 & 1 & 0 & -1.157693 & -1.917131 & 1.895334 \\
\hline 129 & 6 & 0 & -7.531829 & -2.424679 & 3.005633 \\
\hline
\end{tabular}




\begin{tabular}{|c|c|c|c|c|c|}
\hline 130 & 1 & 0 & -8.493833 & -1.908913 & 2.903371 \\
\hline 131 & 1 & 0 & -7.619806 & -3.148979 & 3.820791 \\
\hline 132 & 1 & 0 & -6.794981 & -1.668211 & 3.299701 \\
\hline 133 & 6 & 0 & 6.797498 & -2.571896 & -2.526771 \\
\hline 134 & 1 & 0 & 7.758424 & -2.087426 & -2.736078 \\
\hline 135 & 1 & 0 & 6.660929 & -3.381728 & -3.249502 \\
\hline 136 & 1 & 0 & 6.017847 & -1.821876 & -2.703485 \\
\hline 137 & 6 & 0 & 1.897992 & -2.289531 & -1.214509 \\
\hline 138 & 1 & 0 & 1.741684 & -3.230593 & -1.750197 \\
\hline 139 & 1 & 0 & 1.016939 & -1.656988 & -1.373180 \\
\hline 140 & 1 & 0 & 2.749173 & -1.773530 & -1.673403 \\
\hline 141 & 6 & 0 & -2.702374 & -0.087145 & -2.813697 \\
\hline 142 & 1 & 0 & -1.872362 & 0.612910 & -2.663149 \\
\hline 143 & 1 & 0 & -2.786361 & -0.288896 & -3.885726 \\
\hline 144 & 1 & 0 & -3.614988 & 0.427834 & -2.491802 \\
\hline 145 & 1 & 0 & 2.137146 & 2.894733 & 1.990954 \\
\hline 146 & 1 & 0 & 2.087144 & 2.499620 & 1.098166 \\
\hline 147 & 1 & 0 & 2.896201 & 2.439704 & -0.160661 \\
\hline 148 & 1 & 0 & -2.746486 & 3.720722 & 1.062125 \\
\hline 149 & 1 & 0 & -3.002212 & 2.315926 & 1.207670 \\
\hline 150 & 1 & 0 & -2.164833 & 2.564534 & 0.276390 \\
\hline 151 & 1 & 0 & -7.945906 & 1.613517 & 0.650509 \\
\hline 152 & 1 & 0 & -7.149691 & 1.373910 & 2.033949 \\
\hline 153 & 1 & 0 & 6.991348 & 1.687227 & -1.358153 \\
\hline 154 & 1 & 0 & 7.872404 & 1.669088 & -0.843121 \\
\hline 155 & 7 & 0 & 11.926027 & -1.770980 & -0.085392 \\
\hline 156 & 7 & 0 & 10.373122 & 2.769854 & -1.116078 \\
\hline 157 & 7 & 0 & -10.381221 & 2.775329 & 0.140670 \\
\hline 158 & 7 & 0 & -11.819977 & -1.832221 & -0.749641 \\
\hline 159 & 6 & 0 & 11.643061 & -3.164153 & 0.288641 \\
\hline 160 & 6 & 0 & 11.496635 & -4.136151 & -0.700803 \\
\hline 161 & 6 & 0 & 11.520542 & -3.514133 & 1.633899 \\
\hline 162 & 6 & 0 & 11.228866 & -5.458520 & -0.345683 \\
\hline 163 & 1 & 0 & 11.593494 & -3.860720 & -1.760991 \\
\hline 164 & 6 & 0 & 11.252366 & -4.836115 & 1.988840 \\
\hline 165 & 1 & 0 & 11.635976 & -2.747563 & 2.413862 \\
\hline 166 & 6 & 0 & 11.106901 & -5.808477 & 0.999012 \\
\hline 167 & 1 & 0 & 11.113898 & -6.224790 & -1.125911 \\
\hline 168 & 1 & 0 & 11.155742 & -5.112255 & 3.048974 \\
\hline 169 & 1 & 0 & 10.895682 & -6.850630 & 1.279072 \\
\hline 170 & 6 & 0 & 13.316014 & -1.322329 & -0.251371 \\
\hline 171 & 6 & 0 & 14.023863 & -0.824882 & 0.842574 \\
\hline 172 & 6 & 0 & 13.927253 & -1.393794 & -1.503767 \\
\hline 173 & 6 & 0 & 15.343339 & -0.399838 & 0.685117 \\
\hline 174 & 1 & 0 & 13.542564 & -0.768786 & 1.829715 \\
\hline 175 & 6 & 0 & 15.246260 & -0.968391 & -1.661213 \\
\hline 176 & 1 & 0 & 13.368920 & -1.785995 & -2.366171 \\
\hline 177 & 6 & 0 & 15.954509 & -0.471737 & -0.566622 \\
\hline
\end{tabular}




\begin{tabular}{|c|c|c|c|c|c|}
\hline 178 & 1 & 0 & 15.901388 & -0.008091 & 1.547821 \\
\hline 179 & 1 & 0 & 15.728266 & -1.024580 & -2.648121 \\
\hline 180 & 1 & 0 & 16.994397 & -0.136613 & -0.690939 \\
\hline 181 & 6 & 0 & 9.316650 & 3.774896 & -1.302247 \\
\hline 182 & 6 & 0 & 8.898795 & 4.555621 & -0.224710 \\
\hline 183 & 6 & 0 & 8.731465 & 3.947578 & -2.557219 \\
\hline 184 & 6 & 0 & 7.896659 & 5.510020 & -0.401683 \\
\hline 185 & 1 & 0 & 9.360016 & 4.420020 & 0.764293 \\
\hline 186 & 6 & 0 & 7.729243 & 4.901439 & -2.733965 \\
\hline 187 & 1 & 0 & 9.061052 & 3.331847 & -3.406657 \\
\hline 188 & 6 & 0 & 7.312063 & 5.683004 & -1.656224 \\
\hline 189 & 1 & 0 & 7.567671 & 6.125761 & 0.447889 \\
\hline 190 & 1 & 0 & 7.267847 & 5.037767 & -3.722905 \\
\hline 191 & 1 & 0 & 6.522087 & 6.435050 & -1.795842 \\
\hline 192 & 6 & 0 & 11.785500 & 3.154564 & -1.250573 \\
\hline 193 & 6 & 0 & 12.415581 & 3.072964 & -2.492169 \\
\hline 194 & 6 & 0 & 12.496057 & 3.601112 & -0.135710 \\
\hline 195 & 6 & 0 & 13.755834 & 3.438865 & -2.619880 \\
\hline 196 & 1 & 0 & 11.855787 & 2.721450 & -3.370980 \\
\hline 197 & 6 & 0 & 13.836118 & 3.966458 & -0.263371 \\
\hline 198 & 1 & 0 & 11.999065 & 3.665311 & 0.843153 \\
\hline 199 & 6 & 0 & 14.465970 & 3.885711 & -1.505617 \\
\hline 200 & 1 & 0 & 14.252289 & 3.374880 & -3.598952 \\
\hline 201 & 1 & 0 & 14.396395 & 4.318423 & 0.615085 \\
\hline 202 & 1 & 0 & 15.522355 & 4.173969 & -1.606059 \\
\hline 203 & 6 & 0 & -11.515266 & -3.264946 & -0.873540 \\
\hline 204 & 6 & 0 & -11.669749 & -4.108682 & 0.226217 \\
\hline 205 & 6 & 0 & -11.070993 & -3.780837 & -2.091610 \\
\hline 206 & 6 & 0 & -11.381287 & -5.468593 & 0.108312 \\
\hline 207 & 1 & 0 & -12.020187 & -3.702490 & 1.186135 \\
\hline 208 & 6 & 0 & -10.782167 & -5.140348 & -2.209283 \\
\hline 209 & 1 & 0 & -10.949209 & -3.115377 & -2.958575 \\
\hline 210 & 6 & 0 & -10.937691 & -5.984383 & -1.109363 \\
\hline 211 & 1 & 0 & -11.503575 & -6.133716 & 0.975376 \\
\hline 212 & 1 & 0 & -10.432001 & -5.547233 & -3.169129 \\
\hline 213 & 1 & 0 & -10.710123 & -7.056150 & -1.202418 \\
\hline 214 & 6 & 0 & -13.182780 & -1.345580 & -1.008192 \\
\hline 215 & 6 & 0 & -13.557679 & -0.974025 & -2.299168 \\
\hline 216 & 6 & 0 & -14.101407 & -1.254989 & 0.038295 \\
\hline 217 & 6 & 0 & -14.851364 & -0.512925 & -2.544605 \\
\hline 218 & 1 & 0 & -12.834091 & -1.045653 & -3.124111 \\
\hline 219 & 6 & 0 & -15.394620 & -0.793541 & -0.207071 \\
\hline 220 & 1 & 0 & -13.805566 & -1.547948 & 1.056111 \\
\hline 221 & 6 & 0 & -15.769773 & -0.422846 & -1.498680 \\
\hline 222 & 1 & 0 & -15.146873 & -0.220458 & -3.562583 \\
\hline 223 & 1 & 0 & -16.118834 & -0.722022 & 0.617474 \\
\hline 224 & 1 & 0 & -16.789385 & -0.059279 & -1.691912 \\
\hline 225 & 6 & 0 & -11.761101 & 3.194291 & -0.144466 \\
\hline
\end{tabular}




\begin{tabular}{|c|c|c|c|c|c|}
\hline 226 & 6 & 0 & -12.695875 & 3.266053 & 0.888137 \\
\hline 227 & 6 & 0 & -12.135887 & 3.519885 & -1.448591 \\
\hline 228 & 6 & 0 & -14.005274 & 3.664462 & 0.617553 \\
\hline 229 & 1 & 0 & -12.400726 & 3.009886 & 1.916002 \\
\hline 230 & 6 & 0 & -13.445112 & 3.917734 & -1.719114 \\
\hline 231 & 1 & 0 & -11.398692 & 3.463172 & -2.262608 \\
\hline 232 & 6 & 0 & -14.379796 & 3.990414 & -0.685918 \\
\hline 233 & 1 & 0 & -14.741996 & 3.721404 & 1.431888 \\
\hline 234 & 1 & 0 & -13.740799 & 4.174397 & -2.746814 \\
\hline 235 & 1 & 0 & -15.411811 & 4.304271 & -0.899388 \\
\hline 236 & 6 & 0 & -9.365034 & 3.779333 & 0.487427 \\
\hline 237 & 6 & 0 & -8.644741 & 4.419867 & -0.520598 \\
\hline 238 & 6 & 0 & -9.120748 & 4.091309 & 1.825415 \\
\hline 239 & 6 & 0 & -7.680869 & 5.373318 & -0.191429 \\
\hline 240 & 1 & 0 & -8.837287 & 4.174489 & -1.575093 \\
\hline 241 & 6 & 0 & -8.156759 & 5.044198 & 2.154450 \\
\hline 242 & 1 & 0 & -9.688757 & 3.586098 & 2.620037 \\
\hline 243 & 6 & 0 & -7.437026 & 5.685552 & 1.145956 \\
\hline 244 & 1 & 0 & -7.113403 & 5.878532 & -0.986340 \\
\hline 245 & 1 & 0 & -7.963996 & 5.290286 & 3.208849 \\
\hline 246 & 1 & 0 & -6.677255 & 6.436866 & 1.405578 \\
\hline
\end{tabular}

(M)-V-DABNA-core ( $\mathrm{S}_{0}, C_{1}$ symmetry)

$\mathrm{E}(\mathrm{B} 3 \mathrm{LYP} / 6-31 \mathrm{G}(\mathrm{d}))=-2186.116598$ hartree

\begin{tabular}{rrrrrr} 
Center & Atomic & Atomic & \multicolumn{3}{c}{ Coordinates (Angstroms) } \\
Number & Number & Type & $\mathrm{X}$ & $\mathrm{Z}$ \\
\hline 1 & 7 & 0 & 4.399109 & -3.457389 & 0.892759 \\
2 & 7 & 0 & -2.699291 & 4.257435 & 0.705212 \\
3 & 7 & 0 & -0.744058 & 8.643184 & -0.042988 \\
4 & 7 & 0 & -5.342666 & 0.219544 & 0.571133 \\
5 & 7 & 0 & -8.644793 & -3.186460 & -0.457880 \\
6 & 7 & 0 & -3.944061 & -4.021369 & -1.371716 \\
7 & 6 & 0 & 0.710143 & 5.250741 & -0.387869 \\
8 & 7 & 0 & 8.376612 & -2.512156 & -1.746487 \\
9 & 6 & 0 & -4.071290 & 0.816596 & 0.447849 \\
10 & 6 & 0 & 1.201156 & 2.393070 & -0.094532 \\
11 & 6 & 0 & -0.621722 & 7.232971 & -0.034058 \\
12 & 6 & 0 & 4.745169 & -1.216597 & 0.010678 \\
13 & 6 & 0 & -1.598723 & 5.057000 & 0.341247 \\
14 & 6 & 0 & -4.601071 & -1.896545 & -0.382593 \\
15 & 6 & 0 & 5.185387 & -2.558079 & 0.151552 \\
16 & 6 & 0 & -5.650582 & -1.067456 & 0.092568 \\
17 & 6 & 0 & 2.782006 & -1.743025 & 1.610296 \\
18 & 6 & 0 & -2.942987 & 0.051341 & 0.030049 \\
19 & 6 & 0 & -1.565240 & 2.135485 & 0.174784 \\
20 & 6 & 0 & -4.954947 & -3.172539 & -0.897642
\end{tabular}




\begin{tabular}{|c|c|c|c|c|c|}
\hline 21 & 6 & 0 & -2.564064 & -3.774492 & -1.194249 \\
\hline 22 & 6 & 0 & -2.737613 & 2.856624 & 0.539100 \\
\hline 23 & 6 & 0 & 5.557679 & -0.321556 & -0.731340 \\
\hline 24 & 6 & 0 & 7.158595 & -2.081603 & -1.155842 \\
\hline 25 & 6 & 0 & 3.299331 & -3.065009 & 1.689613 \\
\hline 26 & 6 & 0 & -7.289333 & -2.763379 & -0.432208 \\
\hline 27 & 6 & 0 & -2.109219 & -2.543381 & -0.644001 \\
\hline 28 & 6 & 0 & -0.381059 & 4.426043 & -0.015452 \\
\hline 29 & 6 & 0 & 2.217325 & 3.282410 & -0.549376 \\
\hline 30 & 6 & 0 & 3.860480 & 1.482036 & -0.522208 \\
\hline 31 & 6 & 0 & 2.937739 & 0.620247 & 0.138176 \\
\hline 32 & 7 & 0 & 1.931400 & 4.647145 & -0.749777 \\
\hline 33 & 7 & 0 & 5.141747 & 1.016053 & -0.879704 \\
\hline 34 & 5 & 0 & -0.243537 & 2.917072 & 0.023552 \\
\hline 35 & 5 & 0 & -3.152301 & -1.443504 & -0.324028 \\
\hline 36 & 5 & 0 & 3.429305 & -0.761675 & 0.606228 \\
\hline 37 & 6 & 0 & -3.957756 & 2.190673 & 0.695488 \\
\hline 38 & 1 & 0 & -4.839894 & 2.754585 & 0.958073 \\
\hline 39 & 6 & 0 & -1.739342 & 0.767353 & -0.092260 \\
\hline 40 & 1 & 0 & -0.877724 & 0.233591 & -0.471861 \\
\hline 41 & 6 & 0 & -1.641904 & -4.782160 & -1.546671 \\
\hline 42 & 1 & 0 & -1.985199 & -5.713122 & -1.981209 \\
\hline 43 & 6 & 0 & -0.285780 & -4.606291 & -1.315535 \\
\hline 44 & 1 & 0 & 0.410316 & -5.398199 & -1.579524 \\
\hline 45 & 6 & 0 & 0.185282 & -3.433920 & -0.717761 \\
\hline 46 & 1 & 0 & 1.240877 & -3.313710 & -0.501403 \\
\hline 47 & 6 & 0 & -0.722199 & -2.436315 & -0.396724 \\
\hline 48 & 1 & 0 & -0.350806 & -1.546760 & 0.095840 \\
\hline 49 & 6 & 0 & -6.292511 & -3.584011 & -0.962514 \\
\hline 50 & 1 & 0 & -6.571316 & -4.526460 & -1.410201 \\
\hline 51 & 6 & 0 & -6.974894 & -1.516256 & 0.115638 \\
\hline 52 & 1 & 0 & -7.765974 & -0.917187 & 0.542815 \\
\hline 53 & 6 & 0 & -1.710985 & 6.451268 & 0.362009 \\
\hline 54 & 1 & 0 & -2.619902 & 6.937437 & 0.685945 \\
\hline 55 & 6 & 0 & 0.585506 & 6.643483 & -0.422908 \\
\hline 56 & 1 & 0 & 1.401322 & 7.273131 & -0.748256 \\
\hline 57 & 6 & 0 & 1.629657 & 1.110311 & 0.271692 \\
\hline 58 & 1 & 0 & 0.887682 & 0.445280 & 0.696414 \\
\hline 59 & 6 & 0 & 3.509870 & 2.807959 & -0.809521 \\
\hline 60 & 1 & 0 & 4.246149 & 3.474815 & -1.232496 \\
\hline 61 & 6 & 0 & 6.770413 & -0.743447 & -1.287404 \\
\hline 62 & 1 & 0 & 7.416394 & -0.058313 & -1.818436 \\
\hline 63 & 6 & 0 & 6.366126 & -2.996925 & -0.458101 \\
\hline 64 & 1 & 0 & 6.681713 & -4.028625 & -0.402908 \\
\hline 65 & 6 & 0 & 2.729398 & -3.997502 & 2.580247 \\
\hline 66 & 1 & 0 & 3.113878 & -5.008712 & 2.638214 \\
\hline 67 & 6 & 0 & 1.683353 & -3.624450 & 3.412029 \\
\hline 68 & 1 & 0 & 1.263428 & -4.358661 & 4.094823 \\
\hline
\end{tabular}




\begin{tabular}{rrrrrr}
69 & 6 & 0 & 1.189735 & -2.315972 & 3.392950 \\
70 & 1 & 0 & 0.388359 & -2.018212 & 4.062836 \\
71 & 6 & 0 & 1.741930 & -1.404808 & 2.504507 \\
72 & 1 & 0 & 1.377681 & -0.383035 & 2.509620 \\
73 & 1 & 0 & -9.234904 & -2.402978 & -0.652625 \\
74 & 1 & 0 & -8.764442 & -3.878883 & -1.169382 \\
75 & 1 & 0 & -4.219026 & -4.878426 & -1.807430 \\
76 & 1 & 0 & -6.076514 & 0.750766 & 0.994535 \\
77 & 1 & 0 & -3.516495 & 4.715276 & 1.055295 \\
78 & 1 & 0 & -1.637252 & 9.087006 & -0.115286 \\
79 & 1 & 0 & 0.058278 & 9.236707 & 0.020159 \\
80 & 1 & 0 & 2.654511 & 5.236853 & -1.109436 \\
81 & 1 & 0 & 5.777529 & 1.654516 & -1.313462 \\
82 & 1 & 0 & 8.665744 & -2.114873 & -2.617445 \\
83 & 1 & 0 & 8.954679 & -3.206334 & -1.317585 \\
84 & 1 & 0 & 4.637213 & -4.428189 & 0.863533 \\
\hline-----------------------------------------------------------------------------------------
\end{tabular}

TS-V-DABNA-core $\left(\mathrm{S}_{0}, C_{1}\right.$ symmetry)

$\mathrm{E}(\mathrm{B} 3 \mathrm{LYP} / 6-31 \mathrm{G}(\mathrm{d}))=-2186.100729$ hartree

\begin{tabular}{rrrrrr} 
Center & Atomic & Atomic & \multicolumn{3}{c}{ Coordinates (Angstroms) } \\
Number & Number & Type & $\mathrm{X}$ & $\mathrm{Y}$ & $\mathrm{Z}$ \\
-1 & 7 & 0 & 5.037250 & -3.533074 & 0.129831 \\
2 & 7 & 0 & -2.587431 & 4.282921 & 0.680011 \\
3 & 7 & 0 & -0.381395 & 8.561864 & 0.674771 \\
4 & 7 & 0 & -5.489538 & 0.708626 & -0.399094 \\
5 & 7 & 0 & -8.782397 & -2.318160 & -2.229415 \\
6 & 7 & 0 & -4.528653 & -3.970567 & -0.646485 \\
7 & 6 & 0 & 0.923648 & 5.136476 & 0.193691 \\
8 & 7 & 0 & 8.720604 & -1.900233 & -2.524161 \\
9 & 6 & 0 & -4.212530 & 1.094224 & -0.021061 \\
10 & 6 & 0 & 1.307027 & 2.209659 & 0.138607 \\
11 & 6 & 0 & -0.322763 & 7.169770 & 0.601291 \\
12 & 6 & 0 & 5.033968 & -1.230042 & -0.533367 \\
13 & 6 & 0 & -1.425246 & 5.015745 & 0.611745 \\
14 & 6 & 0 & -4.945234 & -1.610791 & -0.579305 \\
15 & 6 & 0 & 5.650964 & -2.506473 & -0.555230 \\
16 & 6 & 0 & -5.870131 & -0.560715 & -0.790750 \\
17 & 6 & 0 & 3.218584 & -2.175291 & 1.043882 \\
18 & 6 & 0 & -3.147129 & 0.148543 & 0.098217 \\
19 & 6 & 0 & -1.549519 & 2.072256 & 0.375400 \\
20 & 6 & 0 & -5.378994 & -2.917378 & -0.916003 \\
21 & 6 & 0 & -3.381236 & -3.888374 & 0.135355 \\
22 & 6 & 0 & -2.700752 & 2.925523 & 0.439649 \\
23 & 6 & 0 & 5.734093 & -0.186700 & -1.187435 \\
24 & 6 & 0 & 7.494002 & -1.687643 & -1.893988 \\
25 & 6 & 0 & 3.945339 & -3.398295 & 0.975357
\end{tabular}




\begin{tabular}{|c|c|c|c|c|c|}
\hline 26 & 6 & 0 & -7.507154 & -2.082694 & -1.712835 \\
\hline 27 & 6 & 0 & -2.829734 & -2.624348 & 0.485143 \\
\hline 28 & 6 & 0 & -0.216018 & 4.314596 & 0.378333 \\
\hline 29 & 6 & 0 & 2.327665 & 3.159056 & -0.200377 \\
\hline 30 & 6 & 0 & 3.955594 & 1.414290 & -0.596545 \\
\hline 31 & 6 & 0 & 3.077562 & 0.427587 & -0.046923 \\
\hline 32 & 7 & 0 & 2.106867 & 4.521214 & -0.141442 \\
\hline 33 & 7 & 0 & 5.194749 & 1.080710 & -1.117636 \\
\hline 34 & 5 & 0 & -0.146299 & 2.778537 & 0.331660 \\
\hline 35 & 5 & 0 & -3.560679 & -1.347762 & -0.004257 \\
\hline 36 & 5 & 0 & 3.697522 & -0.987624 & 0.160030 \\
\hline 37 & 6 & 0 & -3.992891 & 2.446753 & 0.221450 \\
\hline 38 & 1 & 0 & -4.826420 & 3.148450 & 0.182684 \\
\hline 39 & 6 & 0 & -1.854288 & 0.696755 & 0.250786 \\
\hline 40 & 1 & 0 & -1.023440 & -0.002195 & 0.227417 \\
\hline 41 & 6 & 0 & -2.810639 & -5.088553 & 0.598352 \\
\hline 42 & 1 & 0 & -3.241520 & -6.042337 & 0.297342 \\
\hline 43 & 6 & 0 & -1.736087 & -5.049820 & 1.472899 \\
\hline 44 & 1 & 0 & -1.315399 & -5.979969 & 1.847185 \\
\hline 45 & 6 & 0 & -1.209804 & -3.819981 & 1.889453 \\
\hline 46 & 1 & 0 & -0.377397 & -3.777042 & 2.584605 \\
\hline 47 & 6 & 0 & -1.740157 & -2.642750 & 1.379854 \\
\hline 48 & 1 & 0 & -1.326382 & -1.692701 & 1.706621 \\
\hline 49 & 6 & 0 & -6.630447 & -3.155467 & -1.497748 \\
\hline 50 & 1 & 0 & -6.941510 & -4.167962 & -1.747672 \\
\hline 51 & 6 & 0 & -7.131983 & -0.778349 & -1.348473 \\
\hline 52 & 1 & 0 & -7.824740 & 0.047462 & -1.498141 \\
\hline 53 & 6 & 0 & -1.488717 & 6.406817 & 0.747482 \\
\hline 54 & 1 & 0 & -2.441795 & 6.898948 & 0.931395 \\
\hline 55 & 6 & 0 & 0.889486 & 6.529973 & 0.310207 \\
\hline 56 & 1 & 0 & 1.793704 & 7.117368 & 0.162819 \\
\hline 57 & 6 & 0 & 1.767387 & 0.877045 & 0.239066 \\
\hline 58 & 1 & 0 & 1.050709 & 0.127732 & 0.559681 \\
\hline 59 & 6 & 0 & 3.596714 & 2.758526 & -0.617024 \\
\hline 60 & 1 & 0 & 4.312503 & 3.506787 & -0.958102 \\
\hline 61 & 6 & 0 & 6.938786 & -0.398064 & -1.862402 \\
\hline 62 & 1 & 0 & 7.452197 & 0.426220 & -2.353615 \\
\hline 63 & 6 & 0 & 6.849752 & -2.745567 & -1.238113 \\
\hline 64 & 1 & 0 & 7.298580 & -3.736947 & -1.236574 \\
\hline 65 & 6 & 0 & 3.601214 & -4.506613 & 1.772492 \\
\hline 66 & 1 & 0 & 4.176512 & -5.427492 & 1.690753 \\
\hline 67 & 6 & 0 & 2.547910 & -4.415664 & 2.665876 \\
\hline 68 & 1 & 0 & 2.283601 & -5.274411 & 3.277898 \\
\hline 69 & 6 & 0 & 1.831149 & -3.217622 & 2.780649 \\
\hline 70 & 1 & 0 & 0.964217 & -3.169878 & 3.433975 \\
\hline 71 & 6 & 0 & 2.166638 & -2.131844 & 1.982829 \\
\hline 72 & 1 & 0 & 1.608281 & -1.207824 & 2.094474 \\
\hline 73 & 1 & 0 & -9.212488 & -1.522068 & -2.683380 \\
\hline
\end{tabular}




$\begin{array}{rrrrrr}74 & 1 & 0 & -8.866652 & -3.156040 & -2.791279 \\ 75 & 1 & 0 & -4.875195 & -4.900029 & -0.842170 \\ 76 & 1 & 0 & -6.166014 & 1.449714 & -0.521888 \\ 77 & 1 & 0 & -3.452140 & 4.802500 & 0.744902 \\ 78 & 1 & 0 & -1.150093 & 8.927838 & 1.222530 \\ 79 & 1 & 0 & 0.492653 & 9.013236 & 0.913897 \\ 80 & 1 & 0 & 2.899456 & 5.117961 & -0.334494 \\ 81 & 1 & 0 & 5.726648 & 1.832059 & -1.535130 \\ 82 & 1 & 0 & 8.947156 & -1.235413 & -3.253150 \\ 83 & 1 & 0 & 8.887505 & -2.852547 & -2.824160 \\ 84 & 1 & 0 & 5.508165 & -4.427616 & 0.136844\end{array}$

V-DABNA-core ( $\mathrm{S}_{0}, C_{2}$ symmetry) $\mathrm{E}(\mathrm{B} 3 \mathrm{LYP} / \mathrm{TZP})=-24.12298$ hartree

\begin{tabular}{|c|c|c|c|c|}
\hline \multirow{2}{*}{$\begin{array}{l}\text { Center } \\
\text { Number }\end{array}$} & \multirow{2}{*}{$\begin{array}{l}\text { Atomic } \\
\text { Symbol }\end{array}$} & \multicolumn{3}{|c|}{ Coordinates (Angstroms) } \\
\hline & & $\mathrm{X}$ & $\mathrm{Y}$ & $\mathrm{Z}$ \\
\hline 1 & $\mathrm{~N}$ & -0.940546 & -4.384771 & -4.822591 \\
\hline 2 & $\mathrm{~N}$ & -0.329416 & 2.372441 & 3.438866 \\
\hline 3 & $\mathrm{~N}$ & 0.000000 & 0.000000 & 7.605244 \\
\hline 4 & $\mathrm{~N}$ & -0.153060 & 5.356306 & -0.263521 \\
\hline 5 & $\mathrm{~N}$ & -0.405796 & 8.840734 & -3.580757 \\
\hline 6 & $\mathrm{~N}$ & 0.940546 & 4.384771 & -4.822591 \\
\hline 7 & $\mathrm{C}$ & 0.164440 & -1.190885 & 4.133876 \\
\hline 8 & $\mathrm{~N}$ & 0.405796 & -8.840734 & -3.580757 \\
\hline 9 & $\mathrm{C}$ & -0.036108 & 4.056360 & 0.196409 \\
\hline 10 & $\mathrm{C}$ & -0.016434 & -1.410069 & 1.219119 \\
\hline 11 & $\mathrm{C}$ & 0.000000 & 0.000000 & 6.228729 \\
\hline 12 & $\mathrm{C}$ & -0.391928 & -4.816358 & -2.533488 \\
\hline 13 & $\mathrm{C}$ & -0.164440 & 1.190885 & 4.133876 \\
\hline 14 & $\mathrm{C}$ & 0.391928 & 4.816358 & -2.533488 \\
\hline 15 & $\mathrm{C}$ & -0.540420 & -5.282807 & -3.860718 \\
\hline 16 & $\mathrm{C}$ & -0.012714 & 5.771118 & -1.571093 \\
\hline 17 & $\mathrm{C}$ & -1.237875 & -2.490942 & -3.306938 \\
\hline 18 & $\mathrm{C}$ & 0.307940 & 2.993623 & -0.689271 \\
\hline 19 & $\mathrm{C}$ & 0.016434 & 1.410069 & 1.219119 \\
\hline 20 & $\mathrm{C}$ & 0.540420 & 5.282807 & -3.860718 \\
\hline 21 & $\mathrm{C}$ & 1.330695 & 3.072705 & -4.598038 \\
\hline 22 & $\mathrm{C}$ & -0.188636 & 2.533795 & 2.071070 \\
\hline 23 & $\mathrm{C}$ & 0.012714 & -5.771118 & -1.571093 \\
\hline 24 & $\mathrm{C}$ & 0.104910 & -7.522239 & -3.230542 \\
\hline 25 & $\mathrm{C}$ & -1.330695 & -3.072705 & -4.598038 \\
\hline 26 & $\mathrm{C}$ & -0.104910 & 7.522239 & -3.230542 \\
\hline 27 & $\mathrm{C}$ & 1.237875 & 2.490942 & -3.306938 \\
\hline 28 & $\mathrm{C}$ & 0.000000 & 0.000000 & 3.391293 \\
\hline 29 & $\mathrm{C}$ & 0.188636 & -2.533795 & 2.071070 \\
\hline
\end{tabular}




\begin{tabular}{|c|c|c|c|c|}
\hline 30 & $\mathrm{C}$ & 0.036108 & -4.056360 & 0.196409 \\
\hline 31 & $\mathrm{C}$ & -0.307940 & -2.993623 & -0.689271 \\
\hline 32 & $\mathrm{~N}$ & 0.329416 & -2.372441 & 3.438866 \\
\hline 33 & $\mathrm{~N}$ & 0.153060 & -5.356306 & -0.263521 \\
\hline 34 & $\mathrm{~B}$ & 0.000000 & 0.000000 & 1.870857 \\
\hline 35 & $\mathrm{~B}$ & 0.651195 & 3.365335 & -2.158910 \\
\hline 36 & $\mathrm{~B}$ & -0.651195 & -3.365335 & -2.158910 \\
\hline 37 & $\mathrm{C}$ & -0.251699 & 3.825954 & 1.554196 \\
\hline 38 & $\mathrm{H}$ & -0.456871 & 4.662947 & 2.216941 \\
\hline 39 & $\mathrm{C}$ & 0.280804 & 1.709221 & -0.124376 \\
\hline 40 & $\mathrm{H}$ & 0.488481 & 0.876655 & -0.777787 \\
\hline 41 & $\mathrm{C}$ & 1.831269 & 2.348824 & -5.693864 \\
\hline 42 & $\mathrm{H}$ & 1.878214 & 2.820177 & -6.670797 \\
\hline 43 & $\mathrm{C}$ & 2.273822 & 1.052109 & -5.526338 \\
\hline 44 & $\mathrm{H}$ & 2.660813 & 0.502431 & -6.376420 \\
\hline 45 & $\mathrm{C}$ & 2.234912 & 0.459024 & -4.261123 \\
\hline 46 & $\mathrm{H}$ & 2.595608 & -0.552194 & -4.120732 \\
\hline 47 & $\mathrm{C}$ & 1.728373 & 1.173523 & -3.189982 \\
\hline 48 & $\mathrm{H}$ & 1.729435 & 0.698799 & -2.219681 \\
\hline 49 & $\mathrm{C}$ & 0.292855 & 6.612540 & -4.212531 \\
\hline 50 & $\mathrm{H}$ & 0.406156 & 6.940130 & -5.240828 \\
\hline 51 & $\mathrm{C}$ & -0.255530 & 7.103540 & -1.903620 \\
\hline 52 & $\mathrm{H}$ & -0.574931 & 7.811708 & -1.146042 \\
\hline 53 & $\mathrm{C}$ & -0.173589 & 1.201178 & 5.528236 \\
\hline 54 & $\mathrm{H}$ & -0.303166 & 2.130937 & 6.072508 \\
\hline 55 & $\mathrm{C}$ & 0.173589 & -1.201178 & 5.528236 \\
\hline 56 & $\mathrm{H}$ & 0.303166 & -2.130937 & 6.072508 \\
\hline 57 & $\mathrm{C}$ & -0.280804 & -1.709221 & -0.124376 \\
\hline 58 & $\mathrm{H}$ & -0.488481 & -0.876655 & -0.777787 \\
\hline 59 & $\mathrm{C}$ & 0.251699 & -3.825954 & 1.554196 \\
\hline 60 & $\mathrm{H}$ & 0.456871 & -4.662947 & 2.216941 \\
\hline 61 & $\mathrm{C}$ & 0.255530 & -7.103540 & -1.903620 \\
\hline 62 & $\mathrm{H}$ & 0.574931 & -7.811708 & -1.146042 \\
\hline 63 & $\mathrm{C}$ & -0.292855 & -6.612540 & -4.212531 \\
\hline 64 & $\mathrm{H}$ & -0.406156 & -6.940130 & -5.240828 \\
\hline 65 & $\mathrm{C}$ & -1.831269 & -2.348824 & -5.693864 \\
\hline 66 & $\mathrm{H}$ & -1.878214 & -2.820177 & -6.670797 \\
\hline 67 & $\mathrm{C}$ & -2.273822 & -1.052109 & -5.526338 \\
\hline 68 & $\mathrm{H}$ & -2.660813 & -0.502431 & -6.376420 \\
\hline 69 & $\mathrm{C}$ & -2.234912 & -0.459024 & -4.261123 \\
\hline 70 & $\mathrm{H}$ & -2.595608 & 0.552194 & -4.120732 \\
\hline 71 & $\mathrm{C}$ & -1.728373 & -1.173523 & -3.189982 \\
\hline 72 & $\mathrm{H}$ & -1.729435 & -0.698799 & -2.219681 \\
\hline 73 & $\mathrm{H}$ & 1.051852 & 4.734654 & -5.761056 \\
\hline 74 & $\mathrm{H}$ & -0.432840 & 6.052310 & 0.409497 \\
\hline 75 & $\mathrm{H}$ & -0.438019 & 3.212283 & 3.985230 \\
\hline 76 & $\mathrm{H}$ & 0.438019 & -3.212283 & 3.985230 \\
\hline 77 & $\mathrm{H}$ & 0.432840 & -6.052310 & 0.409497 \\
\hline
\end{tabular}




$\begin{array}{llrrr}78 & \mathrm{H} & -1.051852 & -4.734654 & -5.761056 \\ 79 & \mathrm{H} & -0.046502 & -9.166994 & -4.422036 \\ 80 & \mathrm{H} & 0.314616 & -9.508174 & -2.829144 \\ 81 & \mathrm{H} & 0.046502 & 9.166994 & -4.422036 \\ 82 & \mathrm{H} & -0.314616 & 9.508174 & -2.829144 \\ 83 & \mathrm{H} & -0.128017 & 0.850316 & 8.120766 \\ 84 & \mathrm{H} & 0.128017 & -0.850316 & 8.120766\end{array}$

V-DABNA-core ( $\mathrm{S}_{1}, C_{1}$ symmetry)

$\mathrm{E}(\mathrm{B} 3 \mathrm{LYP} / \mathrm{TZP})=-24.01729$ hartree

\begin{tabular}{|c|c|c|c|c|}
\hline \multirow{2}{*}{$\begin{array}{l}\text { Center } \\
\text { Number }\end{array}$} & \multirow{2}{*}{$\begin{array}{l}\text { Atomic } \\
\text { Symbol }\end{array}$} & \multicolumn{3}{|c|}{ Coordinates (Angstroms) } \\
\hline & & $\mathrm{X}$ & Y & $\mathrm{Z}$ \\
\hline 1 & $\mathrm{~N}$ & -1.121966 & -4.346509 & -4.332336 \\
\hline 2 & $\mathrm{~N}$ & -0.046675 & 2.385652 & 3.946055 \\
\hline 3 & $\mathrm{~N}$ & 0.000000 & 0.000000 & 8.130598 \\
\hline 4 & $\mathrm{~N}$ & 0.214677 & 5.361905 & 0.247001 \\
\hline 5 & $\mathrm{~N}$ & 0.204355 & 8.902181 & -3.036347 \\
\hline 6 & $\mathrm{~N}$ & 1.121966 & 4.346509 & -4.332336 \\
\hline 7 & $\mathrm{C}$ & 0.022864 & -1.193378 & 4.641495 \\
\hline 8 & $\mathrm{~N}$ & -0.204355 & -8.902181 & -3.036347 \\
\hline 9 & $\mathrm{C}$ & 0.256800 & 4.059231 & 0.701815 \\
\hline 10 & $\mathrm{C}$ & -0.133261 & -1.397844 & 1.716473 \\
\hline 11 & $\mathrm{C}$ & 0.000000 & 0.000000 & 6.749899 \\
\hline 12 & $\mathrm{C}$ & -0.653987 & -4.801003 & -2.033540 \\
\hline 13 & $\mathrm{C}$ & -0.022864 & 1.193378 & 4.641495 \\
\hline 14 & $\mathrm{C}$ & 0.653987 & 4.801003 & -2.033540 \\
\hline 15 & $\mathrm{C}$ & -0.802438 & -5.265218 & -3.359821 \\
\hline 16 & $\mathrm{C}$ & 0.344986 & 5.775670 & -1.062641 \\
\hline 17 & $\mathrm{C}$ & -1.310444 & -2.424775 & -2.834035 \\
\hline 18 & $\mathrm{C}$ & 0.482797 & 2.973291 & -0.201057 \\
\hline 19 & $\mathrm{C}$ & 0.133261 & 1.397844 & 1.716473 \\
\hline 20 & $\mathrm{C}$ & 0.802438 & 5.265218 & -3.359821 \\
\hline 21 & $\mathrm{C}$ & 1.421318 & 3.007439 & -4.127982 \\
\hline 22 & $\mathrm{C}$ & 0.056168 & 2.540297 & 2.578492 \\
\hline 23 & $\mathrm{C}$ & -0.344986 & -5.775670 & -1.062641 \\
\hline 24 & $\mathrm{C}$ & -0.319716 & -7.545042 & -2.712969 \\
\hline 25 & $\mathrm{C}$ & -1.421318 & -3.007439 & -4.127982 \\
\hline 26 & $\mathrm{C}$ & 0.319716 & 7.545042 & -2.712969 \\
\hline 27 & $\mathrm{C}$ & 1.310444 & 2.424775 & -2.834035 \\
\hline 28 & $\mathrm{C}$ & 0.000000 & 0.000000 & 3.894829 \\
\hline 29 & $\mathrm{C}$ & -0.056168 & -2.540297 & 2.578492 \\
\hline 30 & $\mathrm{C}$ & -0.256800 & -4.059231 & 0.701815 \\
\hline 31 & $\mathrm{C}$ & -0.482797 & -2.973291 & -0.201057 \\
\hline 32 & $\mathrm{~N}$ & 0.046675 & -2.385652 & 3.946055 \\
\hline 33 & $\mathrm{~N}$ & -0.214677 & -5.361905 & 0.247001 \\
\hline 34 & $\mathrm{~B}$ & 0.000000 & 0.000000 & 2.372749 \\
\hline
\end{tabular}




\begin{tabular}{|c|c|c|c|c|}
\hline 35 & $\mathrm{~B}$ & 0.815013 & 3.332281 & -1.672011 \\
\hline 36 & $\mathrm{~B}$ & -0.815013 & -3.332281 & -1.672011 \\
\hline 37 & $\mathrm{C}$ & 0.078045 & 3.839274 & 2.069769 \\
\hline 38 & $\mathrm{H}$ & -0.035568 & 4.685181 & 2.742670 \\
\hline 39 & $\mathrm{C}$ & 0.366807 & 1.683733 & 0.357744 \\
\hline 40 & $\mathrm{H}$ & 0.477549 & 0.844786 & -0.308273 \\
\hline 41 & $\mathrm{C}$ & 1.847356 & 2.261491 & -5.239284 \\
\hline 42 & $\mathrm{H}$ & 1.906933 & 2.737144 & -6.213373 \\
\hline 43 & $\mathrm{C}$ & 2.206496 & 0.934173 & -5.088492 \\
\hline 44 & $\mathrm{H}$ & 2.536439 & 0.364416 & -5.948995 \\
\hline 45 & $\mathrm{C}$ & 2.148658 & 0.338810 & -3.825951 \\
\hline 46 & $\mathrm{H}$ & 2.437490 & -0.697122 & -3.698881 \\
\hline 47 & $\mathrm{C}$ & 1.709520 & 1.075585 & -2.737018 \\
\hline 48 & $\mathrm{H}$ & 1.689001 & 0.591519 & -1.771587 \\
\hline 49 & $\mathrm{C}$ & 0.632343 & 6.611142 & -3.704682 \\
\hline 50 & $\mathrm{H}$ & 0.758257 & 6.934914 & -4.732715 \\
\hline 51 & $\mathrm{C}$ & 0.179534 & 7.126635 & -1.384892 \\
\hline 52 & $\mathrm{H}$ & -0.051068 & 7.852285 & -0.611527 \\
\hline 53 & $\mathrm{C}$ & -0.028764 & 1.208552 & 6.040847 \\
\hline 54 & $\mathrm{H}$ & -0.051120 & 2.150661 & 6.579184 \\
\hline 55 & $\mathrm{C}$ & 0.028764 & -1.208552 & 6.040847 \\
\hline 56 & $\mathrm{H}$ & 0.051120 & -2.150661 & 6.579184 \\
\hline 57 & $\mathrm{C}$ & -0.366807 & -1.683733 & 0.357744 \\
\hline 58 & $\mathrm{H}$ & -0.477549 & -0.844786 & -0.308273 \\
\hline 59 & $\mathrm{C}$ & -0.078045 & -3.839274 & 2.069769 \\
\hline 60 & $\mathrm{H}$ & 0.035568 & -4.685181 & 2.742670 \\
\hline 61 & $\mathrm{C}$ & -0.179534 & -7.126635 & -1.384892 \\
\hline 62 & $\mathrm{H}$ & 0.051068 & -7.852285 & -0.611527 \\
\hline 63 & $\mathrm{C}$ & -0.632343 & -6.611142 & -3.704682 \\
\hline 64 & $\mathrm{H}$ & -0.758257 & -6.934914 & -4.732715 \\
\hline 65 & $\mathrm{C}$ & -1.847356 & -2.261491 & -5.239284 \\
\hline 66 & $\mathrm{H}$ & -1.906933 & -2.737144 & -6.213373 \\
\hline 67 & $\mathrm{C}$ & -2.206496 & -0.934173 & -5.088492 \\
\hline 68 & $\mathrm{H}$ & -2.536439 & -0.364416 & -5.948995 \\
\hline 69 & $\mathrm{C}$ & -2.148658 & -0.338810 & -3.825951 \\
\hline 70 & $\mathrm{H}$ & -2.437490 & 0.697122 & -3.698881 \\
\hline 71 & $\mathrm{C}$ & -1.709520 & -1.075585 & -2.737018 \\
\hline 72 & $\mathrm{H}$ & -1.689001 & -0.591519 & -1.771587 \\
\hline 73 & $\mathrm{H}$ & -0.368444 & 9.434880 & -2.397893 \\
\hline 74 & $\mathrm{H}$ & 0.060077 & -9.080023 & -3.994516 \\
\hline 75 & $\mathrm{H}$ & -0.068951 & 3.232765 & 4.493380 \\
\hline 76 & $\mathrm{H}$ & -0.022382 & 0.859256 & 8.646117 \\
\hline 77 & $\mathrm{H}$ & -0.020668 & -6.073694 & 0.934409 \\
\hline 78 & $\mathrm{H}$ & 0.068951 & -3.232765 & 4.493380 \\
\hline 79 & $\mathrm{H}$ & -1.239532 & -4.694414 & -5.271577 \\
\hline 80 & $\mathrm{H}$ & 0.020668 & 6.073694 & 0.934409 \\
\hline 81 & $\mathrm{H}$ & 1.239532 & 4.694414 & -5.271577 \\
\hline 82 & $\mathrm{H}$ & 0.022382 & -0.859256 & 8.646117 \\
\hline
\end{tabular}


83

$\mathrm{H}$

0.368444

$-9.434880$

$-2.397893$

84

$\mathrm{H}$

$-0.060077$

9.080023

$-3.994516$

V-DABNA-core ( $\mathrm{T}_{1}, C_{1}$ symmetry)

$\mathrm{E}(\mathrm{B} 3 \mathrm{LYP} / \mathrm{TZP})=-24.02627$ hartree

\begin{tabular}{|c|c|c|c|c|}
\hline \multirow{2}{*}{$\begin{array}{l}\text { Center } \\
\text { Number }\end{array}$} & \multirow{2}{*}{$\begin{array}{l}\text { Atomic } \\
\text { Symbol }\end{array}$} & \multicolumn{3}{|c|}{ Coordinates (Angstroms) } \\
\hline & & $\mathrm{X}$ & $\mathrm{Y}$ & $\mathrm{Z}$ \\
\hline 1 & $\mathrm{~N}$ & -1.163273 & -4.375721 & -4.326621 \\
\hline 2 & $\mathrm{~N}$ & -0.057581 & 2.385575 & 3.937255 \\
\hline 3 & $\mathrm{~N}$ & 0.000000 & 0.000000 & 8.121579 \\
\hline 4 & $\mathrm{~N}$ & 0.195495 & 5.365022 & 0.246173 \\
\hline 5 & $\mathrm{~N}$ & 0.202012 & 8.919081 & -3.021429 \\
\hline 6 & $\mathrm{~N}$ & 1.163273 & 4.375721 & -4.326621 \\
\hline 7 & $\mathrm{C}$ & 0.028242 & -1.192729 & 4.632814 \\
\hline 8 & $\mathrm{~N}$ & -0.202012 & -8.919081 & -3.021429 \\
\hline 9 & $\mathrm{C}$ & 0.244365 & 4.062718 & 0.697461 \\
\hline 10 & $\mathrm{C}$ & -0.128952 & -1.397849 & 1.707196 \\
\hline 11 & $\mathrm{C}$ & 0.000000 & 0.000000 & 6.740700 \\
\hline 12 & $\mathrm{C}$ & -0.660894 & -4.814798 & -2.031944 \\
\hline 13 & $\mathrm{C}$ & -0.028242 & 1.192729 & 4.632814 \\
\hline 14 & $\mathrm{C}$ & 0.660894 & 4.814798 & -2.031944 \\
\hline 15 & $\mathrm{C}$ & -0.824746 & -5.286662 & -3.354001 \\
\hline 16 & $\mathrm{C}$ & 0.336310 & 5.784656 & -1.061093 \\
\hline 17 & $\mathrm{C}$ & -1.337387 & -2.446898 & -2.834881 \\
\hline 18 & $\mathrm{C}$ & 0.480424 & 2.978422 & -0.207338 \\
\hline 19 & $\mathrm{C}$ & 0.128952 & 1.397849 & 1.707196 \\
\hline 20 & $\mathrm{C}$ & 0.824746 & 5.286662 & -3.354001 \\
\hline 21 & $\mathrm{C}$ & 1.467430 & 3.036783 & -4.123595 \\
\hline 22 & $\mathrm{C}$ & 0.045987 & 2.540726 & 2.571184 \\
\hline 23 & $\mathrm{C}$ & -0.336310 & -5.784656 & -1.061093 \\
\hline 24 & $\mathrm{C}$ & -0.320835 & -7.560947 & -2.703524 \\
\hline 25 & $\mathrm{C}$ & -1.467430 & -3.036783 & -4.123595 \\
\hline 26 & $\mathrm{C}$ & 0.320835 & 7.560947 & -2.703524 \\
\hline 27 & $\mathrm{C}$ & 1.337387 & 2.446898 & -2.834881 \\
\hline 28 & $\mathrm{C}$ & 0.000000 & 0.000000 & 3.885067 \\
\hline 29 & $\mathrm{C}$ & -0.045987 & -2.540726 & 2.571184 \\
\hline 30 & $\mathrm{C}$ & -0.244365 & -4.062718 & 0.697461 \\
\hline 31 & $\mathrm{C}$ & -0.480424 & -2.978422 & -0.207338 \\
\hline 32 & $\mathrm{~N}$ & 0.057581 & -2.385575 & 3.937255 \\
\hline 33 & $\mathrm{~N}$ & -0.195495 & -5.365022 & 0.246173 \\
\hline 34 & B & 0.000000 & 0.000000 & 2.362971 \\
\hline 35 & B & 0.824154 & 3.345310 & -1.674886 \\
\hline 36 & B & -0.824154 & -3.345310 & -1.674886 \\
\hline 37 & $\mathrm{C}$ & 0.061892 & 3.839779 & 2.064053 \\
\hline 38 & $\mathrm{H}$ & -0.057591 & 4.684206 & 2.737776 \\
\hline 39 & $\mathrm{C}$ & 0.365272 & 1.687364 & 0.348353 \\
\hline
\end{tabular}




\begin{tabular}{|c|c|c|c|c|}
\hline 40 & $\mathrm{H}$ & 0.478170 & 0.849413 & -0.318652 \\
\hline 41 & $\mathrm{C}$ & 1.916619 & 2.300421 & -5.231505 \\
\hline 42 & $\mathrm{H}$ & 1.991264 & 2.783066 & -6.201138 \\
\hline 43 & $\mathrm{C}$ & 2.277892 & 0.973685 & -5.083717 \\
\hline 44 & $\mathrm{H}$ & 2.626247 & 0.410965 & -5.941497 \\
\hline 45 & $\mathrm{C}$ & 2.200451 & 0.370649 & -3.825374 \\
\hline 46 & $\mathrm{H}$ & 2.492091 & -0.664682 & -3.699552 \\
\hline 47 & $\mathrm{C}$ & 1.739560 & 1.097759 & -2.740033 \\
\hline 48 & $\mathrm{H}$ & 1.705640 & 0.607699 & -1.778110 \\
\hline 49 & $\mathrm{C}$ & 0.651274 & 6.633345 & -3.694700 \\
\hline 50 & $\mathrm{H}$ & 0.788659 & 6.962092 & -4.719682 \\
\hline 51 & $\mathrm{C}$ & 0.167670 & 7.135409 & -1.378847 \\
\hline 52 & $\mathrm{H}$ & -0.074988 & 7.856357 & -0.604728 \\
\hline 53 & $\mathrm{C}$ & -0.034290 & 1.207998 & 6.031227 \\
\hline 54 & $\mathrm{H}$ & -0.060522 & 2.150265 & 6.569260 \\
\hline 55 & $\mathrm{C}$ & 0.034290 & -1.207998 & 6.031227 \\
\hline 56 & $\mathrm{H}$ & 0.060522 & -2.150265 & 6.569260 \\
\hline 57 & $\mathrm{C}$ & -0.365272 & -1.687364 & 0.348353 \\
\hline 58 & $\mathrm{H}$ & -0.478170 & -0.849413 & -0.318652 \\
\hline 59 & $\mathrm{C}$ & -0.061892 & -3.839779 & 2.064053 \\
\hline 60 & $\mathrm{H}$ & 0.057591 & -4.684206 & 2.737776 \\
\hline 61 & $\mathrm{C}$ & -0.167670 & -7.135409 & -1.378847 \\
\hline 62 & $\mathrm{H}$ & 0.074988 & -7.856357 & -0.604728 \\
\hline 63 & $\mathrm{C}$ & -0.651274 & -6.633345 & -3.694700 \\
\hline 64 & $\mathrm{H}$ & -0.788659 & -6.962092 & -4.719682 \\
\hline 65 & $\mathrm{C}$ & -1.916619 & -2.300421 & -5.231505 \\
\hline 66 & $\mathrm{H}$ & -1.991264 & -2.783066 & -6.201138 \\
\hline 67 & $\mathrm{C}$ & -2.277892 & -0.973685 & -5.083717 \\
\hline 68 & $\mathrm{H}$ & -2.626247 & -0.410965 & -5.941497 \\
\hline 69 & $\mathrm{C}$ & -2.200451 & -0.370649 & -3.825374 \\
\hline 70 & $\mathrm{H}$ & -2.492091 & 0.664682 & -3.699552 \\
\hline 71 & $\mathrm{C}$ & -1.739560 & -1.097759 & -2.740033 \\
\hline 72 & $\mathrm{H}$ & -1.705640 & -0.607699 & -1.778110 \\
\hline 73 & $\mathrm{H}$ & -0.380038 & 9.446296 & -2.386886 \\
\hline 74 & $\mathrm{H}$ & 0.051278 & -9.101018 & -3.981759 \\
\hline 75 & $\mathrm{H}$ & -0.084312 & 3.232550 & 4.484637 \\
\hline 76 & $\mathrm{H}$ & -0.027313 & 0.858967 & 8.637336 \\
\hline 77 & $\mathrm{H}$ & 0.006325 & -6.073576 & 0.934742 \\
\hline 78 & $\mathrm{H}$ & 0.084312 & -3.232550 & 4.484637 \\
\hline 79 & $\mathrm{H}$ & -1.293639 & -4.729145 & -5.262042 \\
\hline 80 & $\mathrm{H}$ & -0.006325 & 6.073576 & 0.934742 \\
\hline 81 & $\mathrm{H}$ & 1.293639 & 4.729145 & -5.262042 \\
\hline 82 & $\mathrm{H}$ & 0.027313 & -0.858967 & 8.637336 \\
\hline 83 & $\mathrm{H}$ & 0.380038 & -9.446296 & -2.386886 \\
\hline 84 & $\mathrm{H}$ & -0.051278 & 9.101018 & -3.981759 \\
\hline
\end{tabular}

V-DABNA-core ( $\mathrm{T}_{2}, C_{1}$ symmetry) 
$\mathrm{E}(\mathrm{B} 3 \mathrm{LYP} / \mathrm{TZP})=-24.02154$ hartree

\begin{tabular}{|c|c|c|c|c|}
\hline \multirow{2}{*}{$\begin{array}{l}\text { Center } \\
\text { Number }\end{array}$} & \multirow{2}{*}{$\begin{array}{l}\text { Atomic } \\
\text { Symbol }\end{array}$} & \multicolumn{3}{|c|}{ Coordinates (Angstroms) } \\
\hline & & $X$ & $\mathrm{Y}$ & $\mathrm{Z}$ \\
\hline 1 & $\mathrm{~N}$ & -1.163273 & -4.375721 & -4.326621 \\
\hline 1 & $\mathrm{~N}$ & -0.969110 & -4.501354 & -4.796902 \\
\hline 2 & $\mathrm{~N}$ & -0.351813 & 2.366230 & 3.430411 \\
\hline 3 & $\mathrm{~N}$ & 0.000000 & 0.000000 & 7.601047 \\
\hline 4 & $\mathrm{~N}$ & -0.211166 & 5.362537 & -0.253927 \\
\hline 5 & $\mathrm{~N}$ & -0.358675 & 8.950097 & -3.483822 \\
\hline 6 & $\mathrm{~N}$ & 0.969110 & 4.501354 & -4.796902 \\
\hline 7 & $\mathrm{C}$ & 0.175885 & -1.189221 & 4.127877 \\
\hline 8 & $\mathrm{~N}$ & 0.358675 & -8.950097 & -3.483822 \\
\hline 9 & $\mathrm{C}$ & -0.085032 & 4.058164 & 0.189670 \\
\hline 10 & $\mathrm{C}$ & -0.000265 & -1.410113 & 1.206411 \\
\hline 11 & $\mathrm{C}$ & 0.000000 & 0.000000 & 6.223641 \\
\hline 12 & $\mathrm{C}$ & -0.370593 & -4.868255 & -2.514565 \\
\hline 13 & $\mathrm{C}$ & -0.175885 & 1.189221 & 4.127877 \\
\hline 14 & $\mathrm{C}$ & 0.370593 & 4.868255 & -2.514565 \\
\hline 15 & $\mathrm{C}$ & -0.553435 & -5.372267 & -3.818519 \\
\hline 16 & $\mathrm{C}$ & -0.039215 & 5.805130 & -1.545645 \\
\hline 17 & $\mathrm{C}$ & -1.178758 & -2.550086 & -3.337318 \\
\hline 18 & $\mathrm{C}$ & 0.263534 & 3.004043 & -0.710971 \\
\hline 19 & $\mathrm{C}$ & 0.000265 & 1.410113 & 1.206411 \\
\hline 20 & $\mathrm{C}$ & 0.553435 & 5.372267 & -3.818519 \\
\hline 21 & $\mathrm{C}$ & 1.317407 & 3.170150 & -4.614581 \\
\hline 22 & $\mathrm{C}$ & -0.217228 & 2.526797 & 2.062491 \\
\hline 23 & $\mathrm{C}$ & 0.039215 & -5.805130 & -1.545645 \\
\hline 24 & $\mathrm{C}$ & 0.078455 & -7.617302 & -3.153273 \\
\hline 25 & $\mathrm{C}$ & -1.317407 & -3.170150 & -4.614581 \\
\hline 26 & $\mathrm{C}$ & -0.078455 & 7.617302 & -3.153273 \\
\hline 27 & $\mathrm{C}$ & 1.178758 & 2.550086 & -3.337318 \\
\hline 28 & $\mathrm{C}$ & 0.000000 & 0.000000 & 3.380613 \\
\hline 29 & $\mathrm{C}$ & 0.217228 & -2.526797 & 2.062491 \\
\hline 30 & $\mathrm{C}$ & 0.085032 & -4.058164 & 0.189670 \\
\hline 31 & $\mathrm{C}$ & -0.263534 & -3.004043 & -0.710971 \\
\hline 32 & $\mathrm{~N}$ & 0.351813 & -2.366230 & 3.430411 \\
\hline 33 & $\mathrm{~N}$ & 0.211166 & -5.362537 & -0.253927 \\
\hline 34 & B & 0.000000 & 0.000000 & 1.861206 \\
\hline 35 & B & 0.605421 & 3.401066 & -2.171190 \\
\hline 36 & B & -0.605421 & -3.401066 & -2.171190 \\
\hline 37 & $\mathrm{C}$ & -0.298433 & 3.822073 & 1.548384 \\
\hline 38 & $\mathrm{H}$ & -0.510538 & 4.655766 & 2.212969 \\
\hline 39 & $\mathrm{C}$ & 0.252338 & 1.714645 & -0.145961 \\
\hline 40 & $\mathrm{H}$ & 0.469056 & 0.884224 & -0.797664 \\
\hline 41 & $\mathrm{C}$ & 1.814144 & 2.478814 & -5.729710 \\
\hline 42 & $\mathrm{H}$ & 1.893176 & 2.989783 & -6.684404 \\
\hline 43 & $\mathrm{C}$ & 2.210415 & 1.156778 & -5.609365 \\
\hline
\end{tabular}




\begin{tabular}{|c|c|c|c|c|}
\hline 44 & $\mathrm{H}$ & 2.592634 & 0.624844 & -6.471818 \\
\hline 45 & $\mathrm{C}$ & 2.118725 & 0.523758 & -4.367628 \\
\hline 46 & $\mathrm{H}$ & 2.432720 & -0.507327 & -4.260285 \\
\hline 47 & $\mathrm{C}$ & 1.617486 & 1.209535 & -3.271240 \\
\hline 48 & $\mathrm{H}$ & 1.576799 & 0.689456 & -2.326242 \\
\hline 49 & $\mathrm{C}$ & 0.330055 & 6.717342 & -4.144583 \\
\hline 50 & $\mathrm{H}$ & 0.468966 & 7.062349 & -5.164080 \\
\hline 51 & $\mathrm{C}$ & -0.260311 & 7.157951 & -1.847691 \\
\hline 52 & $\mathrm{H}$ & -0.582721 & 7.845360 & -1.072147 \\
\hline 53 & $\mathrm{C}$ & -0.184357 & 1.199577 & 5.521897 \\
\hline 54 & $\mathrm{H}$ & -0.322523 & 2.128341 & 6.065778 \\
\hline 55 & $\mathrm{C}$ & 0.184357 & -1.199577 & 5.521897 \\
\hline 56 & $\mathrm{H}$ & 0.322523 & -2.128341 & 6.065778 \\
\hline 57 & $\mathrm{C}$ & -0.252338 & -1.714645 & -0.145961 \\
\hline 58 & $\mathrm{H}$ & -0.469056 & -0.884224 & -0.797664 \\
\hline 59 & $\mathrm{C}$ & 0.298433 & -3.822073 & 1.548384 \\
\hline 60 & $\mathrm{H}$ & 0.510538 & -4.655766 & 2.212969 \\
\hline 61 & $\mathrm{C}$ & 0.260311 & -7.157951 & -1.847691 \\
\hline 62 & $\mathrm{H}$ & 0.582721 & -7.845360 & -1.072147 \\
\hline 63 & $\mathrm{C}$ & -0.330055 & -6.717342 & -4.144583 \\
\hline 64 & $\mathrm{H}$ & -0.468966 & -7.062349 & -5.164080 \\
\hline 65 & $\mathrm{C}$ & -1.814144 & -2.478814 & -5.729710 \\
\hline 66 & $\mathrm{H}$ & -1.893176 & -2.989783 & -6.684404 \\
\hline 67 & $\mathrm{C}$ & -2.210415 & -1.156778 & -5.609365 \\
\hline 68 & $\mathrm{H}$ & -2.592634 & -0.624844 & -6.471818 \\
\hline 69 & $\mathrm{C}$ & -2.118725 & -0.523758 & -4.367628 \\
\hline 70 & $\mathrm{H}$ & -2.432720 & 0.507327 & -4.260285 \\
\hline 71 & $\mathrm{C}$ & -1.617486 & -1.209535 & -3.271240 \\
\hline 72 & $\mathrm{H}$ & -1.576799 & -0.689456 & -2.326242 \\
\hline 73 & $\mathrm{H}$ & 1.102626 & 4.877620 & -5.723238 \\
\hline 74 & $\mathrm{H}$ & -0.487730 & 6.046776 & 0.433648 \\
\hline 75 & $\mathrm{H}$ & -0.471275 & 3.206067 & 3.974609 \\
\hline 76 & $\mathrm{H}$ & 0.471275 & -3.206067 & 3.974609 \\
\hline 77 & $\mathrm{H}$ & 0.487730 & -6.046776 & 0.433648 \\
\hline 78 & $\mathrm{H}$ & -1.102626 & -4.877620 & -5.723238 \\
\hline 79 & $\mathrm{H}$ & -0.142011 & -9.289503 & -4.292724 \\
\hline 80 & $\mathrm{H}$ & 0.270146 & -9.595499 & -2.712046 \\
\hline 81 & $\mathrm{H}$ & 0.142011 & 9.289503 & -4.292724 \\
\hline 82 & $\mathrm{H}$ & -0.270146 & 9.595499 & -2.712046 \\
\hline 83 & $\mathrm{H}$ & -0.135303 & 0.849126 & 8.116688 \\
\hline 84 & $\mathrm{H}$ & 0.135303 & -0.849126 & 8.116688 \\
\hline
\end{tabular}

v-DABNA-core $\left(\mathrm{S}_{0}, C_{2}\right.$ symmetry)

$\mathrm{E}(\mathrm{B} 3 \mathrm{LYP} / \mathrm{TZP})=-17.12287$ hartree

$\begin{array}{llcl}\text { Center } & \text { Atomic } & & \\ \text { Number } & \text { Symbol } & \mathrm{X} & \mathrm{Y}\end{array}$




\begin{tabular}{|c|c|c|c|c|}
\hline 1 & $\mathrm{C}$ & 0.142896 & 3.658388 & -0.545263 \\
\hline 2 & $\mathrm{C}$ & 0.093436 & 1.206805 & -0.318693 \\
\hline 3 & $\mathrm{C}$ & 0.152866 & 1.239361 & 1.105192 \\
\hline 4 & $\mathrm{C}$ & 0.243418 & 3.817269 & 0.857223 \\
\hline 5 & $\mathrm{C}$ & 0.000000 & 0.000000 & -1.009825 \\
\hline 6 & $\mathrm{C}$ & 0.000000 & 0.000000 & 1.742322 \\
\hline 7 & $\mathrm{C}$ & -0.152866 & -1.239361 & 1.105192 \\
\hline 8 & $\mathrm{C}$ & -0.093436 & -1.206805 & -0.318693 \\
\hline 9 & $\mathrm{C}$ & -0.142896 & -3.658388 & -0.545263 \\
\hline 10 & $\mathrm{C}$ & -0.243418 & -3.817269 & 0.857223 \\
\hline 11 & $\mathrm{H}$ & 0.000000 & 0.000000 & -2.096823 \\
\hline 12 & $\mathrm{H}$ & 0.000000 & 0.000000 & 2.819210 \\
\hline 13 & $\mathrm{C}$ & -0.254467 & -5.145821 & 1.343528 \\
\hline 14 & $\mathrm{C}$ & -0.061648 & -4.748523 & -1.410744 \\
\hline 15 & $\mathrm{C}$ & 0.254467 & 5.145821 & 1.343528 \\
\hline 16 & $\mathrm{C}$ & -0.164140 & -6.248667 & 0.491028 \\
\hline 17 & $\mathrm{H}$ & -0.183480 & -7.257162 & 0.891028 \\
\hline 18 & $\mathrm{C}$ & -0.070272 & -6.047358 & -0.888450 \\
\hline 19 & $\mathrm{H}$ & 0.004692 & -4.597873 & -2.483371 \\
\hline 20 & B & -0.331636 & -2.621339 & 1.789952 \\
\hline 21 & B & 0.331636 & 2.621339 & 1.789952 \\
\hline 22 & $\mathrm{~N}$ & -0.132673 & -2.376682 & -1.056434 \\
\hline 23 & $\mathrm{~N}$ & 0.132673 & 2.376682 & -1.056434 \\
\hline 24 & $\mathrm{H}$ & -0.063577 & -2.285018 & -2.057646 \\
\hline 25 & $\mathrm{C}$ & 0.552368 & 4.347105 & 3.652068 \\
\hline 26 & $\mathrm{C}$ & 0.061648 & 4.748523 & -1.410744 \\
\hline 27 & $\mathrm{H}$ & 1.142663 & 4.141815 & 6.991968 \\
\hline 28 & $\mathrm{H}$ & -1.142663 & -4.141815 & 6.991968 \\
\hline 29 & $\mathrm{H}$ & 0.183480 & 7.257162 & 0.891028 \\
\hline 30 & $\mathrm{C}$ & 0.737878 & 4.753288 & 4.985502 \\
\hline 31 & $\mathrm{C}$ & 0.164140 & 6.248667 & 0.491028 \\
\hline 32 & $\mathrm{C}$ & 0.585636 & 2.976227 & 3.285362 \\
\hline 33 & $\mathrm{H}$ & 0.690467 & 5.808601 & 5.235730 \\
\hline 34 & $\mathrm{C}$ & 0.995519 & 3.818382 & 5.968083 \\
\hline 35 & $\mathrm{H}$ & 0.063577 & 2.285018 & -2.057646 \\
\hline 36 & $\mathrm{H}$ & 0.303809 & -7.998201 & -1.344644 \\
\hline 37 & $\mathrm{H}$ & -0.690467 & -5.808601 & 5.235730 \\
\hline 38 & $\mathrm{~N}$ & -0.041688 & -7.142338 & -1.752383 \\
\hline 39 & $\mathrm{H}$ & -0.303809 & 7.998201 & -1.344644 \\
\hline 40 & $\mathrm{C}$ & -0.995519 & -3.818382 & 5.968083 \\
\hline 41 & $\mathrm{C}$ & -0.552368 & -4.347105 & 3.652068 \\
\hline 42 & $\mathrm{C}$ & -0.737878 & -4.753288 & 4.985502 \\
\hline 43 & $\mathrm{H}$ & 0.373919 & -6.963000 & -2.654130 \\
\hline 44 & $\mathrm{C}$ & -0.585636 & -2.976227 & 3.285362 \\
\hline 45 & $\mathrm{~N}$ & 0.041688 & 7.142338 & -1.752383 \\
\hline 46 & $\mathrm{~N}$ & 0.347848 & 5.337437 & 2.703485 \\
\hline 47 & $\mathrm{~N}$ & -0.347848 & -5.337437 & 2.703485 \\
\hline
\end{tabular}




$\begin{array}{lrrrr}48 & \mathrm{H} & -0.362381 & -6.289366 & 3.034033 \\ 49 & \mathrm{C} & 0.070272 & 6.047358 & -0.888450 \\ 50 & \mathrm{H} & -1.315239 & -1.728172 & 6.397306 \\ 51 & \mathrm{H} & 1.315239 & 1.728172 & 6.397306 \\ 52 & \mathrm{H} & -0.004692 & 4.597873 & -2.483371 \\ 53 & \mathrm{C} & 0.883765 & 2.069189 & 4.323869 \\ 54 & \mathrm{C} & -1.085223 & -2.462991 & 5.635584 \\ 55 & \mathrm{H} & 0.984603 & 1.019194 & 4.089283 \\ 56 & \mathrm{C} & -0.883765 & -2.069189 & 4.323869 \\ 57 & \mathrm{H} & -0.984603 & -1.019194 & 4.089283 \\ 58 & \mathrm{C} & 1.085223 & 2.462991 & 5.635584 \\ 59 & \mathrm{H} & 0.362381 & 6.289366 & 3.034033 \\ 60 & \mathrm{H} & -0.373919 & 6.963000 & -2.654130\end{array}$

v-DABNA-core ( $\mathrm{S}_{1}, C_{1}$ symmetry)

$\mathrm{E}(\mathrm{B} 3 \mathrm{LYP} / \mathrm{TZP})=-17.01279$ hartree

\begin{tabular}{|c|c|c|c|c|}
\hline \multirow{2}{*}{$\begin{array}{l}\text { Center } \\
\text { Number }\end{array}$} & \multirow{2}{*}{$\begin{array}{l}\text { Atomic } \\
\text { Symbol }\end{array}$} & \multicolumn{3}{|c|}{ Coordinates (Angstroms) } \\
\hline & & $\mathrm{X}$ & $\mathrm{Y}$ & Z \\
\hline 1 & $\mathrm{C}$ & 0.146417 & 3.659017 & -0.539108 \\
\hline 2 & $\mathrm{C}$ & 0.073163 & 1.209920 & -0.289144 \\
\hline 3 & $\mathrm{C}$ & 0.122378 & 1.250990 & 1.141498 \\
\hline 4 & $\mathrm{C}$ & 0.243308 & 3.827809 & 0.853343 \\
\hline 5 & $\mathrm{C}$ & 0.000000 & 0.000000 & -0.983096 \\
\hline 6 & $\mathrm{C}$ & 0.000000 & 0.000000 & 1.785330 \\
\hline 7 & $\mathrm{C}$ & -0.122378 & -1.250990 & 1.141498 \\
\hline 8 & $\mathrm{C}$ & -0.073163 & -1.209920 & -0.289144 \\
\hline 9 & $\mathrm{C}$ & -0.146417 & -3.659017 & -0.539108 \\
\hline 10 & $\mathrm{C}$ & -0.243308 & -3.827809 & 0.853343 \\
\hline 11 & $\mathrm{H}$ & 0.000000 & 0.000000 & -2.069746 \\
\hline 12 & $\mathrm{H}$ & 0.000000 & 0.000000 & 2.859104 \\
\hline 13 & $\mathrm{C}$ & -0.294207 & -5.160742 & 1.311251 \\
\hline 14 & $\mathrm{C}$ & -0.098570 & -4.742854 & -1.430087 \\
\hline 15 & $\mathrm{C}$ & 0.294207 & 5.160742 & 1.311251 \\
\hline 16 & $\mathrm{C}$ & -0.242898 & -6.260801 & 0.440621 \\
\hline 17 & $\mathrm{H}$ & -0.290960 & -7.271197 & 0.833277 \\
\hline 18 & $\mathrm{C}$ & -0.143755 & -6.051459 & -0.937941 \\
\hline 19 & $\mathrm{H}$ & -0.033890 & -4.570132 & -2.499609 \\
\hline 20 & B & -0.285526 & -2.640358 & 1.809742 \\
\hline 21 & B & 0.285526 & 2.640358 & 1.809742 \\
\hline 22 & $\mathrm{~N}$ & -0.099933 & -2.373405 & -1.031484 \\
\hline 23 & $\mathrm{~N}$ & 0.099933 & 2.373405 & -1.031484 \\
\hline 24 & $\mathrm{H}$ & -0.042027 & -2.268584 & -2.033104 \\
\hline 25 & $\mathrm{C}$ & 0.513030 & 4.398974 & 3.646506 \\
\hline 26 & $\mathrm{C}$ & 0.098570 & 4.742854 & -1.430087 \\
\hline 27 & $\mathrm{H}$ & 0.947194 & 4.260436 & 7.015604 \\
\hline 28 & $\mathrm{H}$ & -0.947194 & -4.260436 & 7.015604 \\
\hline
\end{tabular}




$\begin{array}{rrrrr}29 & \mathrm{H} & 0.290960 & 7.271197 & 0.833277 \\ 30 & \mathrm{C} & 0.667703 & 4.838600 & 4.969665 \\ 31 & \mathrm{C} & 0.242898 & 6.260801 & 0.440621 \\ 32 & \mathrm{C} & 0.486677 & 3.014315 & 3.304670 \\ 33 & \mathrm{H} & 0.671594 & 5.902759 & 5.183867 \\ 34 & \mathrm{C} & 0.826287 & 3.918141 & 5.995043 \\ 35 & \mathrm{H} & 0.042027 & 2.268584 & -2.033104 \\ 36 & \mathrm{H} & 0.184190 & -8.001557 & -1.422800 \\ 37 & \mathrm{H} & -0.671594 & -5.902759 & 5.183867 \\ 38 & \mathrm{~N} & -0.153815 & -7.137292 & -1.821062 \\ 39 & \mathrm{H} & -0.184190 & 8.001557 & -1.422800 \\ 40 & \mathrm{C} & -0.826287 & -3.918141 & 5.995043 \\ 41 & \mathrm{C} & -0.513030 & -4.398974 & 3.646506 \\ 42 & \mathrm{C} & -0.667703 & -4.838600 & 4.969665 \\ 43 & \mathrm{H} & 0.284951 & -6.954543 & -2.711939 \\ 44 & \mathrm{C} & -0.486677 & -3.014315 & 3.304670 \\ 45 & \mathrm{~N} & 0.153815 & 7.137292 & -1.821062 \\ 46 & \mathrm{~N} & 0.392687 & 5.372806 & 2.663587 \\ 47 & \mathrm{~N} & -0.392687 & -5.372806 & 2.663587 \\ 48 & \mathrm{H} & -0.435048 & -6.330926 & 2.977108 \\ 49 & \mathrm{C} & 0.143755 & 6.051459 & -0.937941 \\ 50 & \mathrm{H} & -0.980106 & -1.829137 & 6.490281 \\ 51 & \mathrm{H} & 0.980106 & 1.829137 & 6.490281 \\ 52 & \mathrm{H} & 0.033890 & 4.570132 & -2.499609 \\ 53 & \mathrm{C} & -6.672821 & 2.125603 & 4.387429 \\ 54 & \mathrm{C} & -0.838899 & -2.554805 & 5.698065 \\ 55 & \mathrm{H} & -0.672821 & -2.125603 & 4.387429 \\ 56 & \mathrm{H} & -0.714389 & -1.064461 & 4.194833 \\ 57 & 0.838899 & 2.554805 & 5.698065 \\ 58 & -0.284951 & 6.954543 & -2.711939 \\ 59 & & & & \\ 60 & ----------\end{array}$

v-DABNA-core ( $\mathrm{T}_{1}, C_{1}$ symmetry)

$\mathrm{E}(\mathrm{B} 3 \mathrm{LYP} / \mathrm{TZP})=-17.02579$ hartree

\begin{tabular}{|c|c|c|c|c|}
\hline \multirow{2}{*}{$\begin{array}{l}\text { Center } \\
\text { Number }\end{array}$} & \multirow{2}{*}{$\begin{array}{l}\text { Atomic } \\
\text { Symbol }\end{array}$} & \multicolumn{3}{|c|}{ Coordinates (Angstroms) } \\
\hline & & $\mathrm{X}$ & $\mathrm{Y}^{\circ}$ & Z \\
\hline 1 & $\mathrm{C}$ & 0.138623 & 3.659858 & -0.537265 \\
\hline 2 & $\mathrm{C}$ & 0.069479 & 1.210239 & -0.288583 \\
\hline 3 & $\mathrm{C}$ & 0.121392 & 1.251765 & 1.146314 \\
\hline 4 & $\mathrm{C}$ & 0.241286 & 3.827692 & 0.855368 \\
\hline 5 & $\mathrm{C}$ & 0.000000 & 0.000000 & -0.981597 \\
\hline 6 & $\mathrm{C}$ & 0.000000 & 0.000000 & 1.789764 \\
\hline 7 & $\mathrm{C}$ & -0.121392 & -1.251765 & 1.146314 \\
\hline 8 & $\mathrm{C}$ & -0.069479 & -1.210239 & -0.288583 \\
\hline 9 & $\mathrm{C}$ & -0.138623 & -3.659858 & -0.537265 \\
\hline
\end{tabular}




\begin{tabular}{|c|c|c|c|c|}
\hline 10 & $\mathrm{C}$ & -0.241286 & -3.827692 & 0.855368 \\
\hline 11 & $\mathrm{H}$ & 0.000000 & 0.000000 & -2.068132 \\
\hline 12 & $\mathrm{H}$ & 0.000000 & 0.000000 & 2.863321 \\
\hline 13 & $\mathrm{C}$ & -0.295696 & -5.162539 & 1.310263 \\
\hline 14 & $\mathrm{C}$ & -0.087957 & -4.740007 & -1.427323 \\
\hline 15 & $\mathrm{C}$ & 0.295696 & 5.162539 & 1.310263 \\
\hline 16 & $\mathrm{C}$ & -0.241229 & -6.260352 & 0.439356 \\
\hline 17 & $\mathrm{H}$ & -0.291409 & -7.271123 & 0.831117 \\
\hline 18 & $\mathrm{C}$ & -0.135734 & -6.050429 & -0.937835 \\
\hline 19 & $\mathrm{H}$ & -0.019400 & -4.566071 & -2.496579 \\
\hline 20 & B & -0.286562 & -2.642626 & 1.811148 \\
\hline 21 & $\mathrm{~B}$ & 0.286562 & 2.642626 & 1.811148 \\
\hline 22 & $\mathrm{~N}$ & -0.090457 & -2.370357 & -1.028680 \\
\hline 23 & $\mathrm{~N}$ & 0.090457 & 2.370357 & -1.028680 \\
\hline 24 & $\mathrm{H}$ & -0.031303 & -2.264810 & -2.030261 \\
\hline 25 & $\mathrm{C}$ & 0.523746 & 4.403848 & 3.644989 \\
\hline 26 & $\mathrm{C}$ & 0.087957 & 4.740007 & -1.427323 \\
\hline 27 & $\mathrm{H}$ & 0.971190 & 4.269530 & 7.012541 \\
\hline 28 & $\mathrm{H}$ & -0.971190 & -4.269530 & 7.012541 \\
\hline 29 & $\mathrm{H}$ & 0.291409 & 7.271123 & 0.831117 \\
\hline 30 & $\mathrm{C}$ & 0.685149 & 4.844467 & 4.966847 \\
\hline 31 & $\mathrm{C}$ & 0.241229 & 6.260352 & 0.439356 \\
\hline 32 & $\mathrm{C}$ & 0.492611 & 3.017969 & 3.303186 \\
\hline 33 & $\mathrm{H}$ & 0.692458 & 5.909131 & 5.178783 \\
\hline 34 & $\mathrm{C}$ & 0.845431 & 3.926667 & 5.992969 \\
\hline 35 & $\mathrm{H}$ & 0.031303 & 2.264810 & -2.030261 \\
\hline 36 & $\mathrm{H}$ & 0.192813 & -7.999621 & -1.424769 \\
\hline 37 & $\mathrm{H}$ & -0.692458 & -5.909131 & 5.178783 \\
\hline 38 & $\mathrm{~N}$ & -0.142948 & -7.135032 & -1.824407 \\
\hline 39 & $\mathrm{H}$ & -0.192813 & 7.999621 & -1.424769 \\
\hline 40 & $\mathrm{C}$ & -0.845431 & -3.926667 & 5.992969 \\
\hline 41 & $\mathrm{C}$ & -0.523746 & -4.403848 & 3.644989 \\
\hline 42 & $\mathrm{C}$ & -0.685149 & -4.844467 & 4.966847 \\
\hline 43 & $\mathrm{H}$ & 0.306738 & -6.950847 & -2.709643 \\
\hline 44 & $\mathrm{C}$ & -0.492611 & -3.017969 & 3.303186 \\
\hline 45 & $\mathrm{~N}$ & 0.142948 & 7.135032 & -1.824407 \\
\hline 46 & $\mathrm{~N}$ & 0.400883 & 5.377089 & 2.662899 \\
\hline 47 & $\mathrm{~N}$ & -0.400883 & -5.377089 & 2.662899 \\
\hline 48 & $\mathrm{H}$ & -0.445013 & -6.335566 & 2.974949 \\
\hline 49 & $\mathrm{C}$ & 0.135734 & 6.050429 & -0.937835 \\
\hline 50 & $\mathrm{H}$ & -0.996175 & -1.836897 & 6.487925 \\
\hline 51 & $\mathrm{H}$ & 0.996175 & 1.836897 & 6.487925 \\
\hline 52 & $\mathrm{H}$ & 0.019400 & 4.566071 & -2.496579 \\
\hline 53 & $\mathrm{C}$ & 0.681271 & 2.131444 & 4.387849 \\
\hline 54 & $\mathrm{C}$ & -0.853173 & -2.562202 & 5.695625 \\
\hline 55 & $\mathrm{H}$ & 0.718585 & 1.069836 & 4.197448 \\
\hline 56 & $\mathrm{C}$ & -0.681271 & -2.131444 & 4.387849 \\
\hline 57 & $\mathrm{H}$ & -0.718585 & -1.069836 & 4.197448 \\
\hline
\end{tabular}




$\begin{array}{rrrrr}58 & \mathrm{C} & 0.853173 & 2.562202 & 5.695625 \\ 59 & \mathrm{H} & 0.445013 & 6.335566 & 2.974949 \\ 60 & \mathrm{H} & -0.306738 & 6.950847 & -2.709643\end{array}$

v-DABNA-core ( $\mathrm{T}_{2}, C_{1}$ symmetry)

$\mathrm{E}(\mathrm{B} 3 \mathrm{LYP} / \mathrm{TZP})=-17.01949$ hartree

\begin{tabular}{|c|c|c|c|c|}
\hline \multirow{2}{*}{$\begin{array}{l}\text { Center } \\
\text { Number }\end{array}$} & \multirow{2}{*}{$\begin{array}{l}\text { Atomic } \\
\text { Symbol }\end{array}$} & \multicolumn{3}{|c|}{ Coordinates (Angstroms) } \\
\hline & & $\mathrm{X}$ & $\mathrm{Y}$ & $\mathrm{Z}$ \\
\hline 1 & $\mathrm{C}$ & 0.145526 & 3.655585 & -0.540145 \\
\hline 2 & $\mathrm{C}$ & 0.075309 & 1.219377 & -0.240478 \\
\hline 3 & $\mathrm{C}$ & 0.122447 & 1.258856 & 1.171574 \\
\hline 4 & $\mathrm{C}$ & 0.243135 & 3.832603 & 0.859179 \\
\hline 5 & $\mathrm{C}$ & 0.000000 & 0.000000 & -0.942257 \\
\hline 6 & $\mathrm{C}$ & 0.000000 & 0.000000 & 1.813226 \\
\hline 7 & $\mathrm{C}$ & -0.122447 & -1.258856 & 1.171574 \\
\hline 8 & $\mathrm{C}$ & -0.075309 & -1.219377 & -0.240478 \\
\hline 9 & $\mathrm{C}$ & -0.145526 & -3.655585 & -0.540145 \\
\hline 10 & $\mathrm{C}$ & -0.243135 & -3.832603 & 0.859179 \\
\hline 11 & $\mathrm{H}$ & 0.000000 & 0.000000 & -2.028766 \\
\hline 12 & $\mathrm{H}$ & 0.000000 & 0.000000 & 2.887689 \\
\hline 13 & $\mathrm{C}$ & -0.295247 & -5.170192 & 1.304838 \\
\hline 14 & $\mathrm{C}$ & -0.092009 & -4.729187 & -1.450581 \\
\hline 15 & $\mathrm{C}$ & 0.295247 & 5.170192 & 1.304838 \\
\hline 16 & $\mathrm{C}$ & -0.243812 & -6.250179 & 0.416192 \\
\hline 17 & $\mathrm{H}$ & -0.297634 & -7.266642 & 0.792919 \\
\hline 18 & $\mathrm{C}$ & -0.137840 & -6.030998 & -0.971788 \\
\hline 19 & $\mathrm{H}$ & -0.018799 & -4.539918 & -2.516582 \\
\hline 20 & B & -0.285536 & -2.654363 & 1.826532 \\
\hline 21 & B & 0.285536 & 2.654363 & 1.826532 \\
\hline 22 & $\mathrm{~N}$ & -0.100452 & -2.368005 & -1.010008 \\
\hline 23 & $\mathrm{~N}$ & 0.100452 & 2.368005 & -1.010008 \\
\hline 24 & $\mathrm{H}$ & -0.046787 & -2.244193 & -2.010084 \\
\hline 25 & $\mathrm{C}$ & 0.525084 & 4.436835 & 3.644598 \\
\hline 26 & $\mathrm{C}$ & 0.092009 & 4.729187 & -1.450581 \\
\hline 27 & $\mathrm{H}$ & 0.988122 & 4.321669 & 7.010204 \\
\hline 28 & $\mathrm{H}$ & -0.988122 & -4.321669 & 7.010204 \\
\hline 29 & $\mathrm{H}$ & 0.297634 & 7.266642 & 0.792919 \\
\hline 30 & $\mathrm{C}$ & 0.692273 & 4.883011 & 4.962693 \\
\hline 31 & $\mathrm{C}$ & 0.243812 & 6.250179 & 0.416192 \\
\hline 32 & $\mathrm{C}$ & 0.494469 & 3.051702 & 3.314538 \\
\hline 33 & $\mathrm{H}$ & 0.700542 & 5.948702 & 5.170006 \\
\hline 34 & $\mathrm{C}$ & 0.857264 & 3.971058 & 5.993742 \\
\hline 35 & $\mathrm{H}$ & 0.046787 & 2.244193 & -2.010084 \\
\hline 36 & $\mathrm{H}$ & 0.223106 & -7.978066 & -1.443603 \\
\hline 37 & $\mathrm{H}$ & -0.700542 & -5.948702 & 5.170006 \\
\hline 38 & $\mathrm{~N}$ & -0.144066 & -7.126535 & -1.843847 \\
\hline
\end{tabular}




\begin{tabular}{|c|c|c|c|c|}
\hline 39 & $\mathrm{H}$ & -0.223106 & 7.978066 & -1.443603 \\
\hline 40 & $\mathrm{C}$ & -0.857264 & -3.971058 & 5.993742 \\
\hline 41 & $\mathrm{C}$ & -0.525084 & -4.436835 & 3.644598 \\
\hline 42 & $\mathrm{C}$ & -0.692273 & -4.883011 & 4.962693 \\
\hline 43 & $\mathrm{H}$ & 0.273859 & -6.943855 & -2.744910 \\
\hline 44 & $\mathrm{C}$ & -0.494469 & -3.051702 & 3.314538 \\
\hline 45 & $\mathrm{~N}$ & 0.144066 & 7.126535 & -1.843847 \\
\hline 46 & $\mathrm{~N}$ & 0.395178 & 5.405966 & 2.654858 \\
\hline 47 & $\mathrm{~N}$ & -0.395178 & -5.405966 & 2.654858 \\
\hline 48 & $\mathrm{H}$ & -0.444275 & -6.366668 & 2.955820 \\
\hline 49 & $\mathrm{C}$ & 0.137840 & 6.030998 & -0.971788 \\
\hline 50 & $\mathrm{H}$ & -1.010346 & -1.884326 & 6.502592 \\
\hline 51 & $\mathrm{H}$ & 1.010346 & 1.884326 & 6.502592 \\
\hline 52 & $\mathrm{H}$ & 0.018799 & 4.539918 & -2.516582 \\
\hline 53 & $\mathrm{C}$ & 0.686557 & 2.170456 & 4.401326 \\
\hline 54 & $\mathrm{C}$ & -0.863630 & -2.605367 & 5.707195 \\
\hline 55 & $\mathrm{H}$ & 0.720316 & 1.107872 & 4.214180 \\
\hline 56 & $\mathrm{C}$ & -0.686557 & -2.170456 & 4.401326 \\
\hline 57 & $\mathrm{H}$ & -0.720316 & -1.107872 & 4.214180 \\
\hline 58 & $\mathrm{C}$ & 0.863630 & 2.605367 & 5.707195 \\
\hline 59 & $\mathrm{H}$ & 0.444275 & 6.366668 & 2.955820 \\
\hline 60 & $\mathrm{H}$ & -0.273859 & 6.943855 & -2.744910 \\
\hline
\end{tabular}




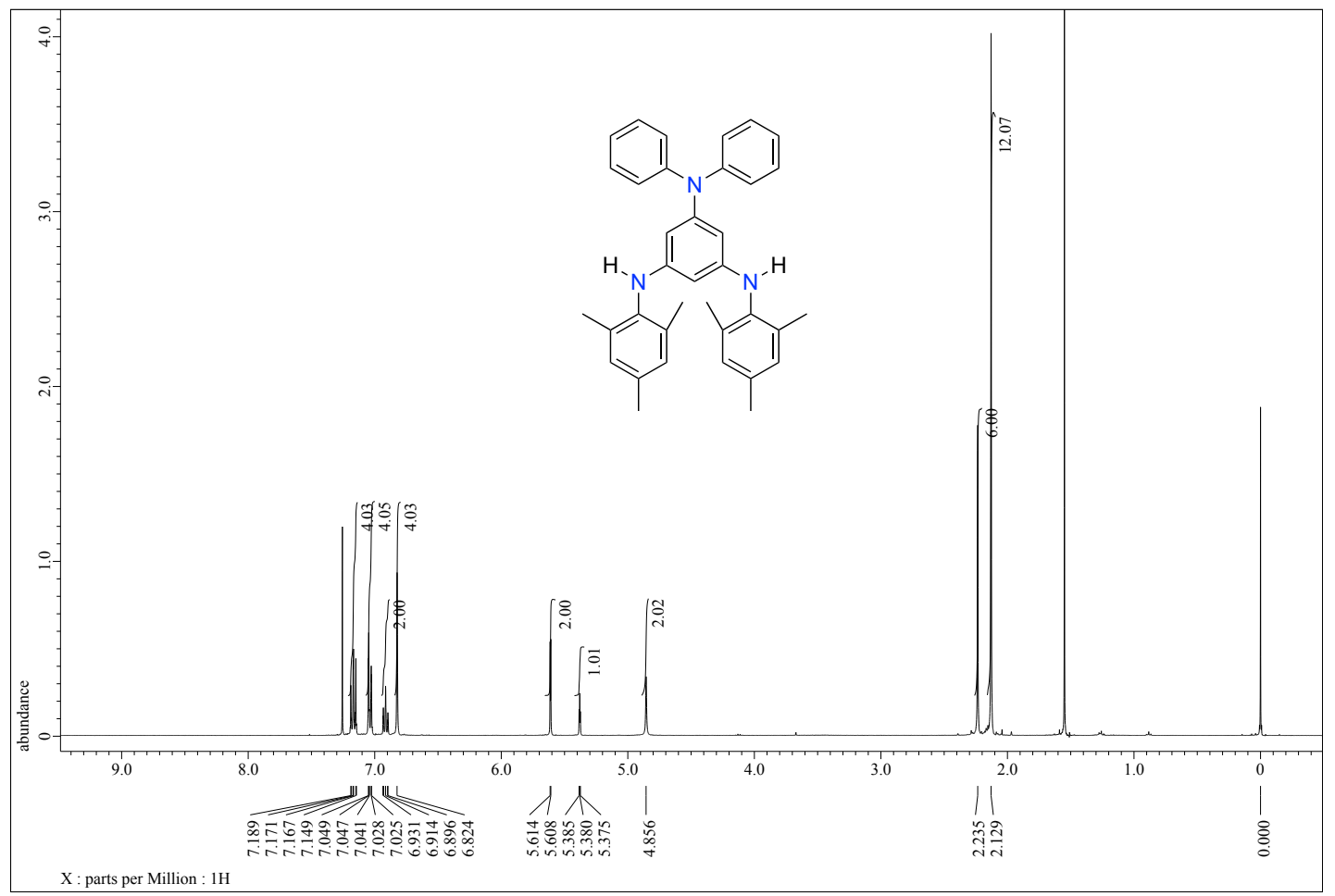

Figure S10. ${ }^{1} \mathrm{H}$ NMR spectrum of $\mathbf{S 1}$ in $\mathrm{CDCl}_{3}$ at $25{ }^{\circ} \mathrm{C}$.

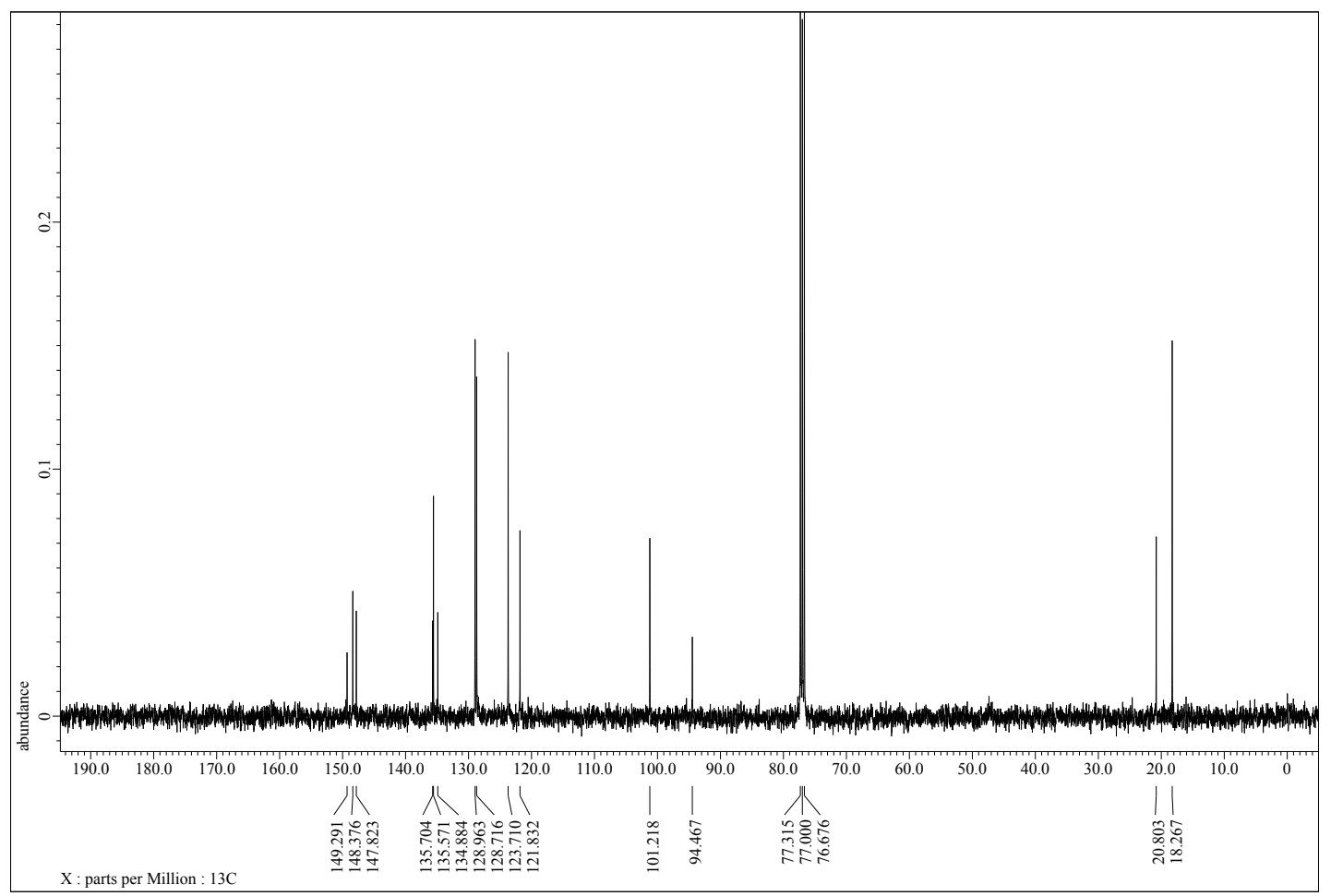

Figure S11. ${ }^{13} \mathrm{C}$ NMR spectrum of $\mathbf{S 1}$ in $\mathrm{CDCl}_{3}$ at $25{ }^{\circ} \mathrm{C}$. 


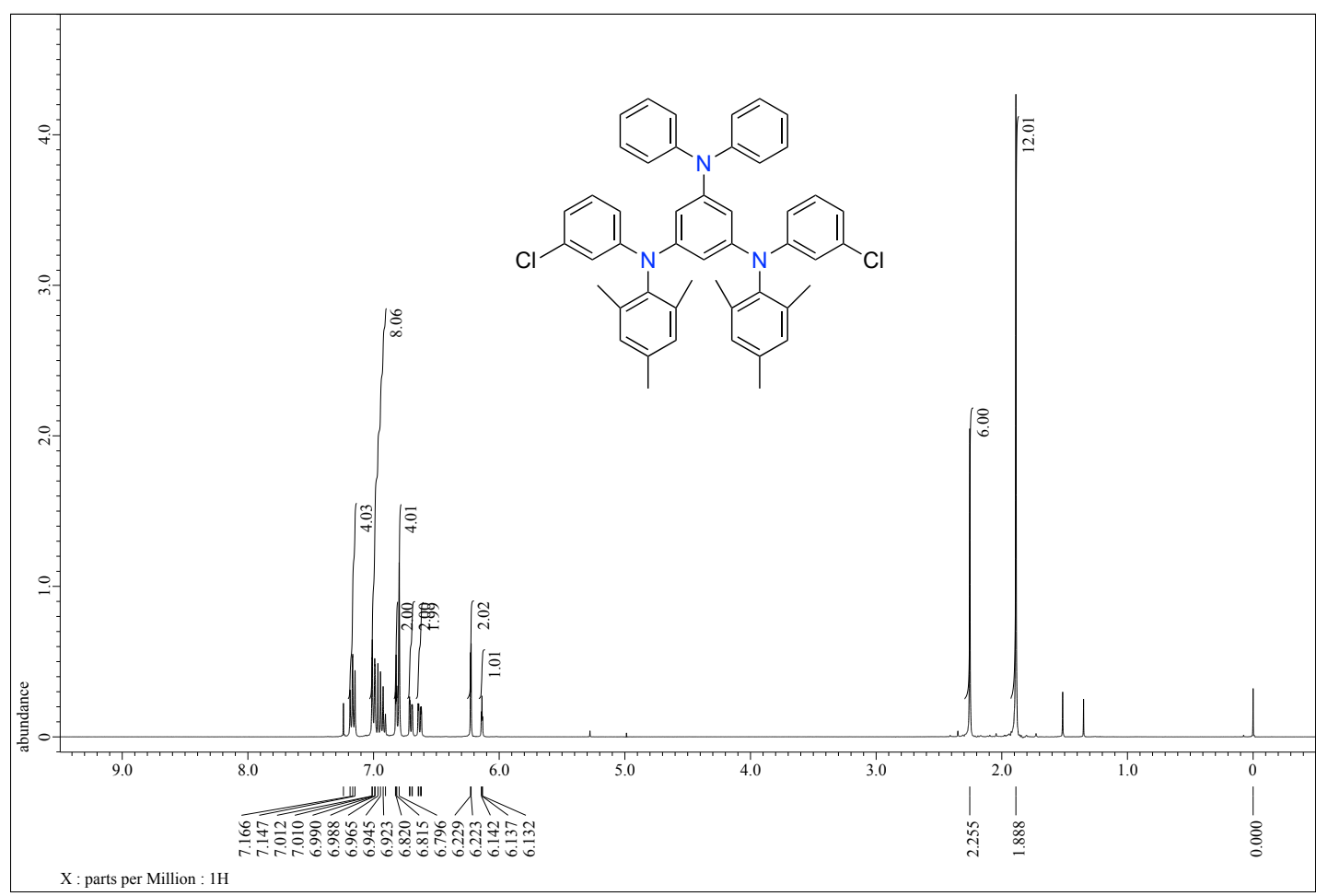

Figure S12. ${ }^{1} \mathrm{H}$ NMR spectrum of $\mathbf{S 2}$ in $\mathrm{CDCl}_{3}$ at $25{ }^{\circ} \mathrm{C}$.

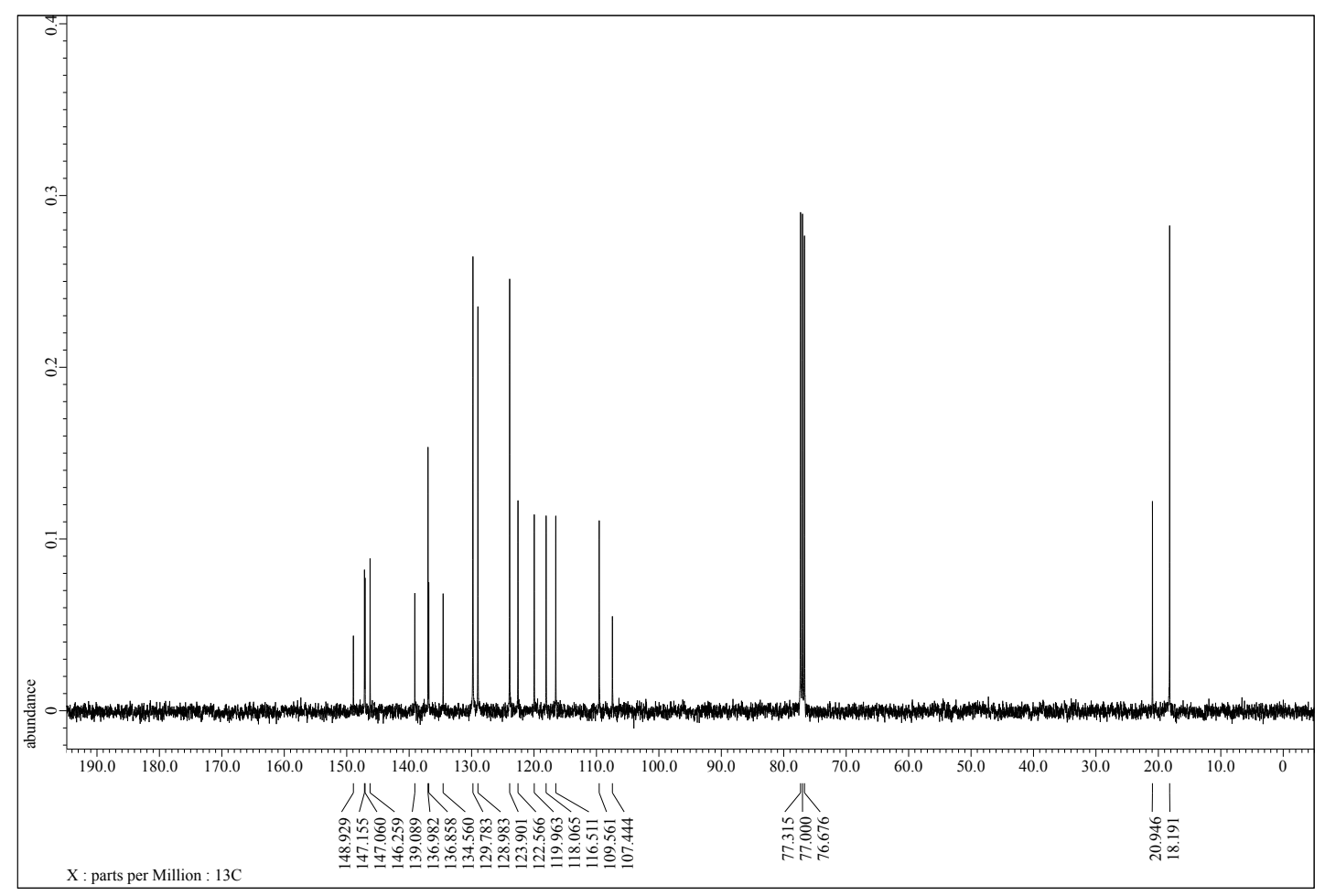

Figure S13. ${ }^{13} \mathrm{C}$ NMR spectrum of $\mathbf{S 2}$ in $\mathrm{CDCl}_{3}$ at $25{ }^{\circ} \mathrm{C}$. 


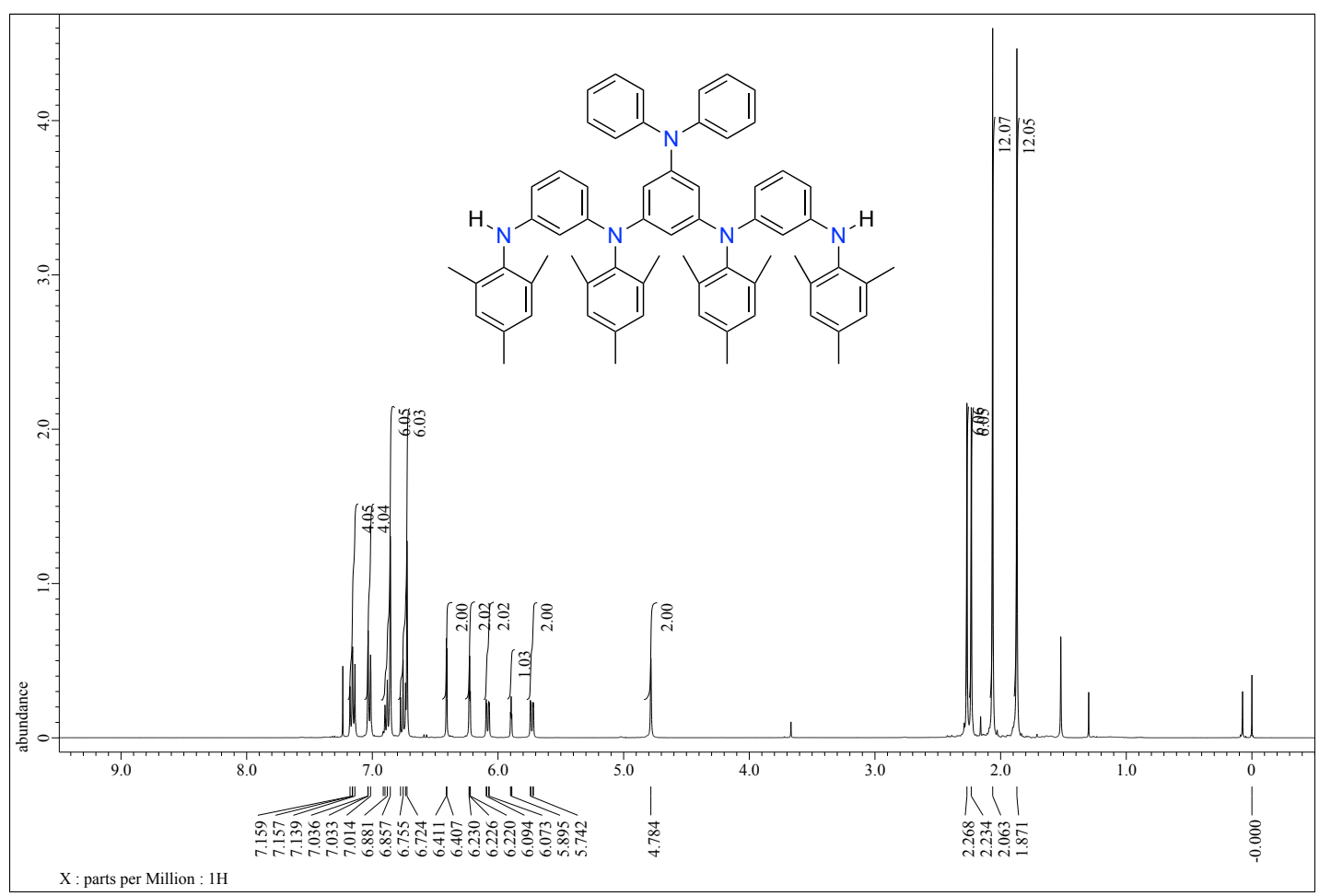

Figure S14. ${ }^{1} \mathrm{H}$ NMR spectrum of $\mathbf{S 3}$ in $\mathrm{CDCl}_{3}$ at $25{ }^{\circ} \mathrm{C}$.

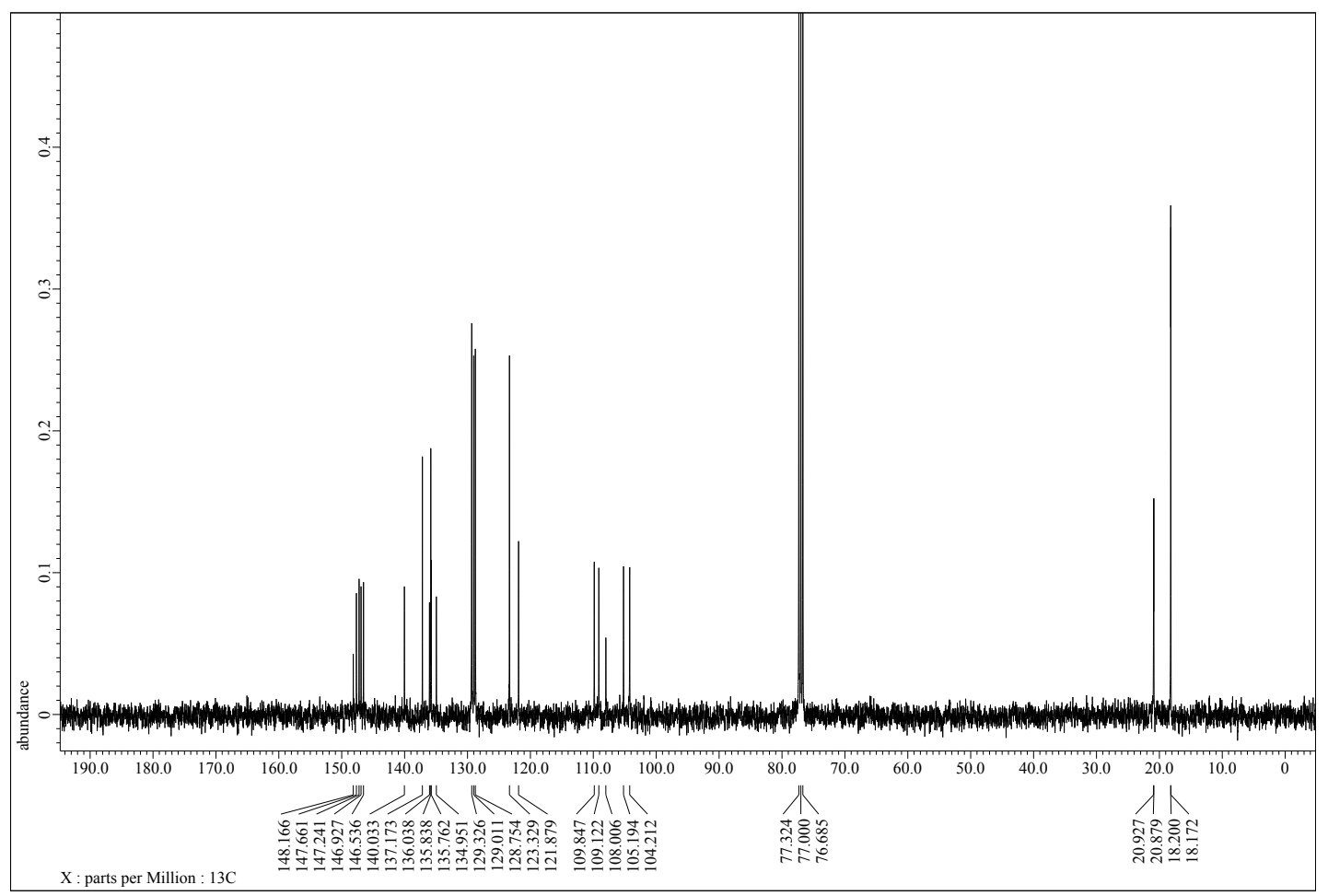

Figure S15. ${ }^{13} \mathrm{C}$ NMR spectrum of $\mathbf{S 3}$ in $\mathrm{CDCl}_{3}$ at $25{ }^{\circ} \mathrm{C}$. 


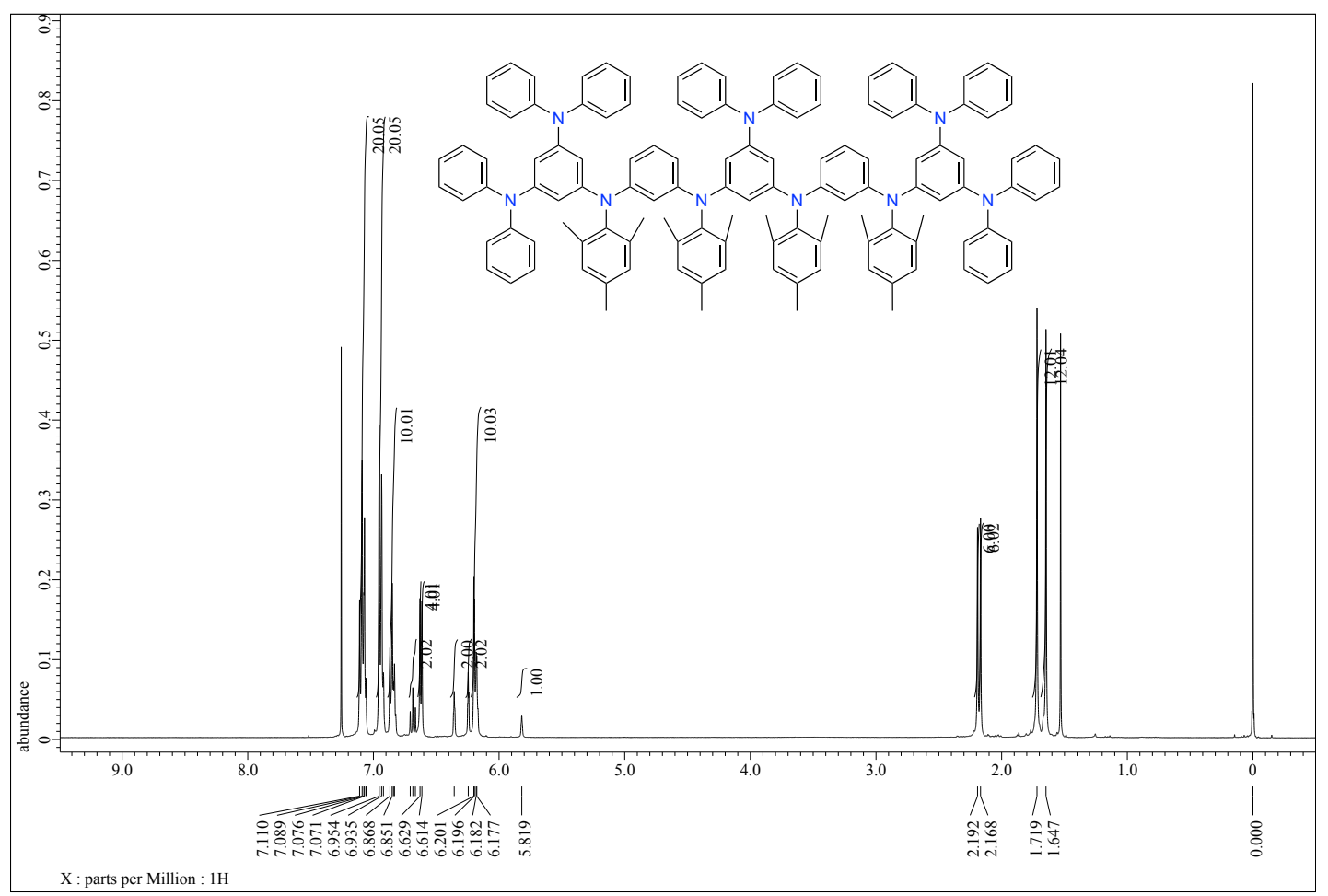

Figure S16. ${ }^{1} \mathrm{H}$ NMR spectrum of 1 in $\mathrm{CDCl}_{3}$ at $25{ }^{\circ} \mathrm{C}$.

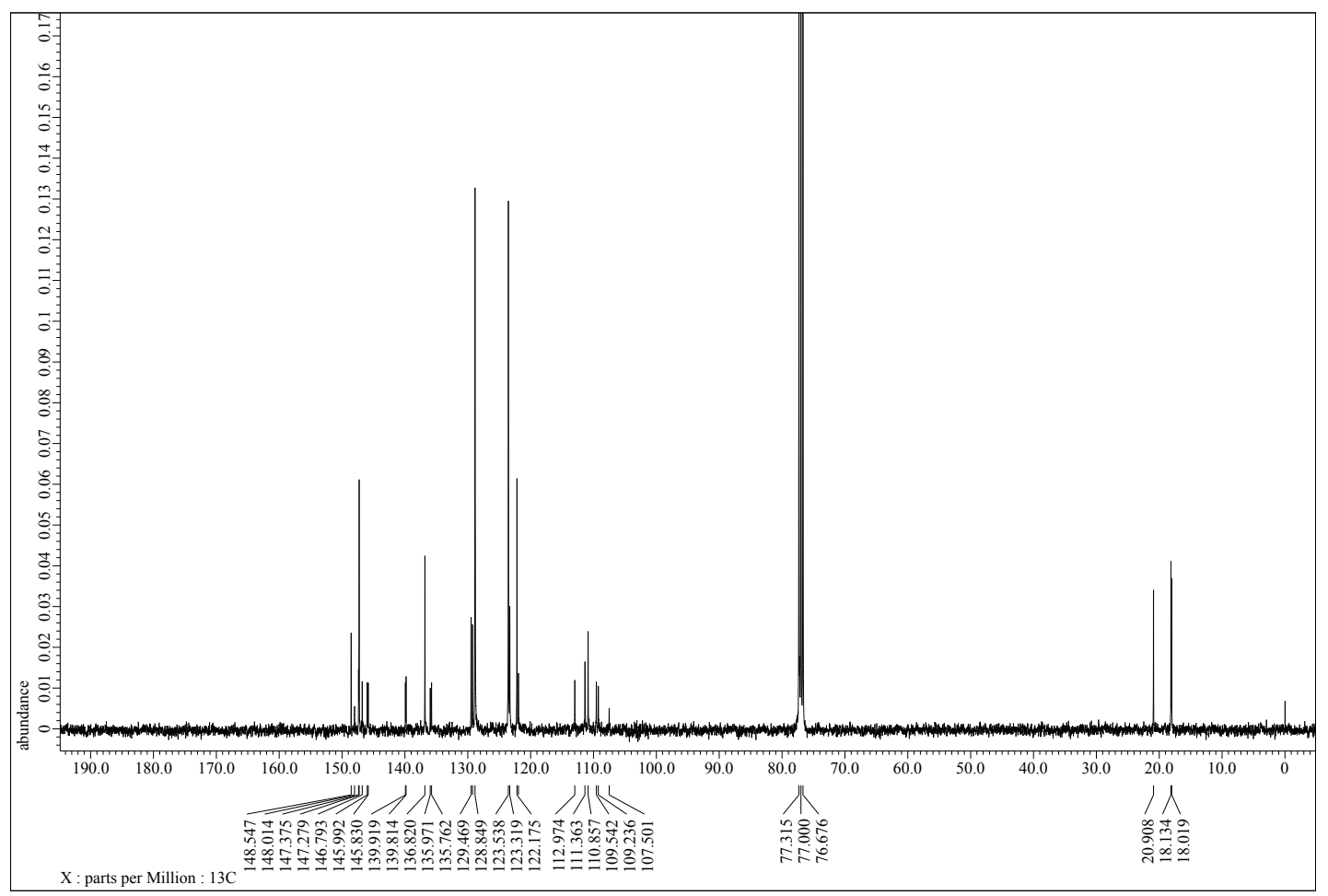

Figure S17. ${ }^{13} \mathrm{C}$ NMR spectrum of 1 in $\mathrm{CDCl}_{3}$ at $25^{\circ} \mathrm{C}$. 


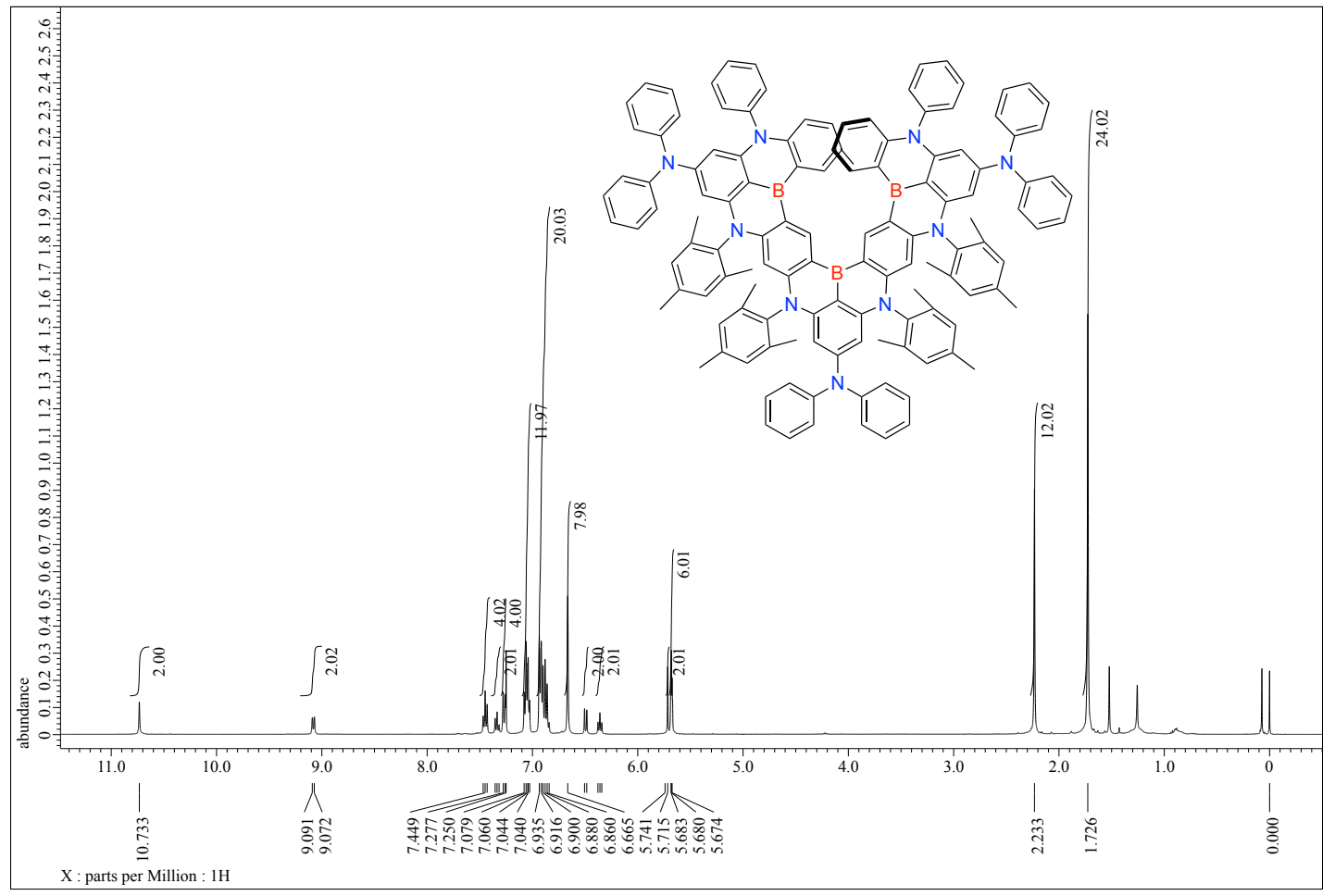

Figure S18. ${ }^{1} \mathrm{H}$ NMR spectrum of V-DABNA-Mes in $\mathrm{CDCl}_{3}$ at $25{ }^{\circ} \mathrm{C}$.

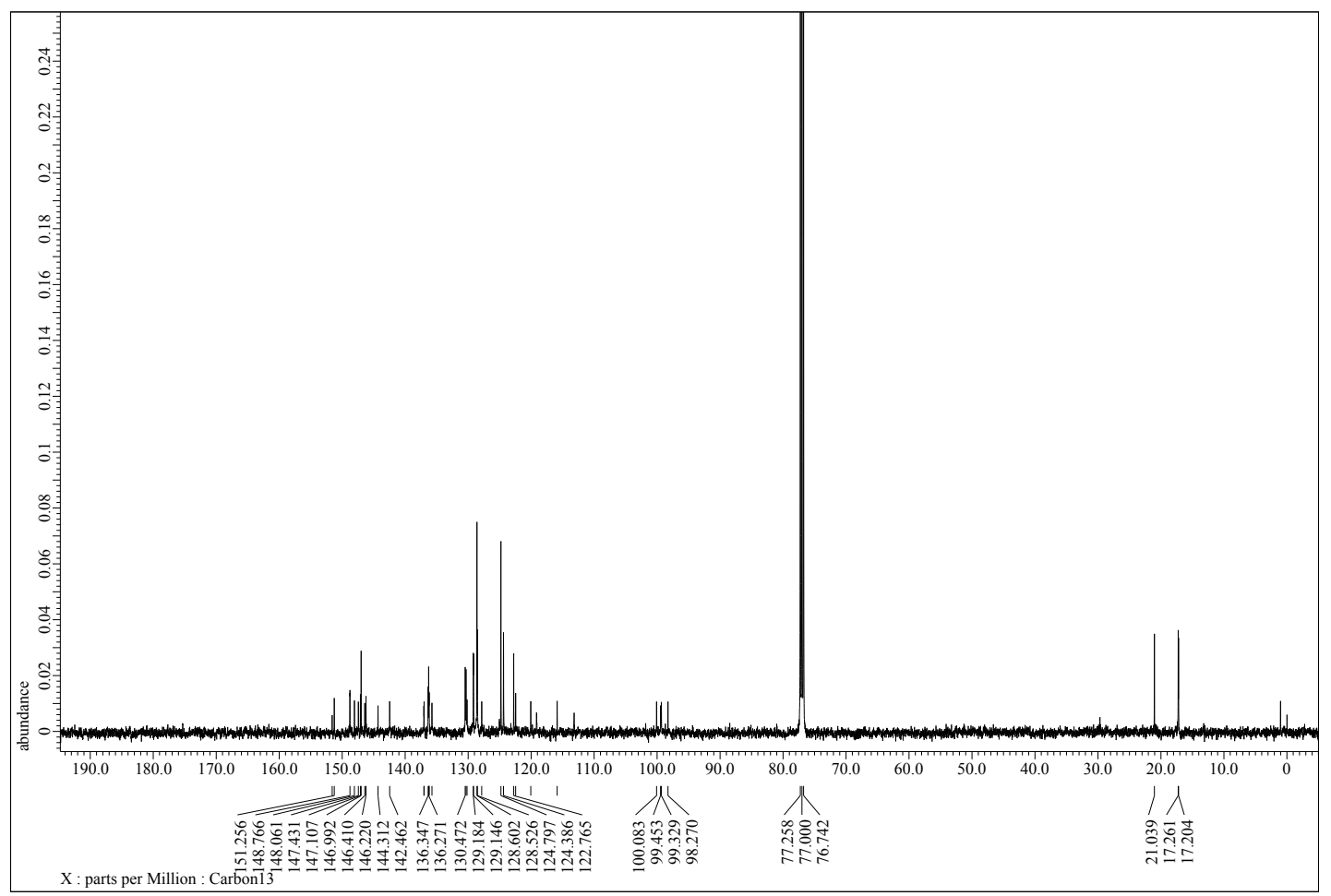

Figure S19. ${ }^{13} \mathrm{C}$ NMR spectrum of V-DABNA-Mes in $\mathrm{CDCl}_{3}$ at $25{ }^{\circ} \mathrm{C}$. 


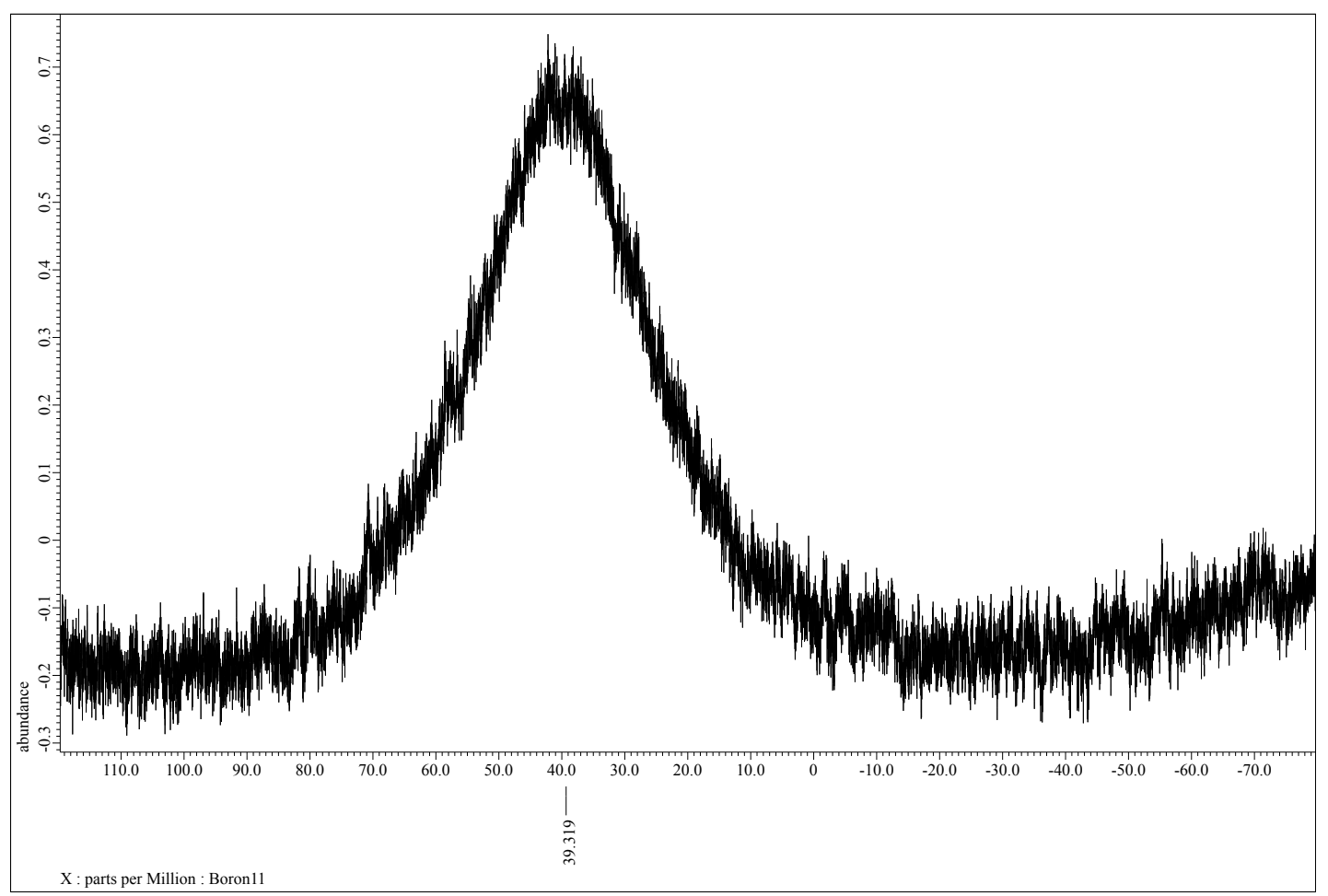

Figure S20. ${ }^{11} \mathrm{~B}$ NMR spectrum of V-DABNA-Mes in $\mathrm{CDCl}_{3}$ at $25{ }^{\circ} \mathrm{C}$. 